\title{
2012 Market Report on Wind Technologies in Distributed Applications
}

August 2013

\section{AC Orrell}

Pacific Northwest National Laboratory

\section{HE Rhoads-Weaver}

MN Gagne

KM Sahl

BH Pro

RE Baranowski

eFormative Options

\section{LT Flowers}

American Wind Energy Association

\section{JO Jenkins}

Distributed Wind Energy Association

Prepared for

the U.S. Department of Energy

under Contract DE-AC05-76RL01830

Pacific Northwest National Laboratory Richland, Washington 99352
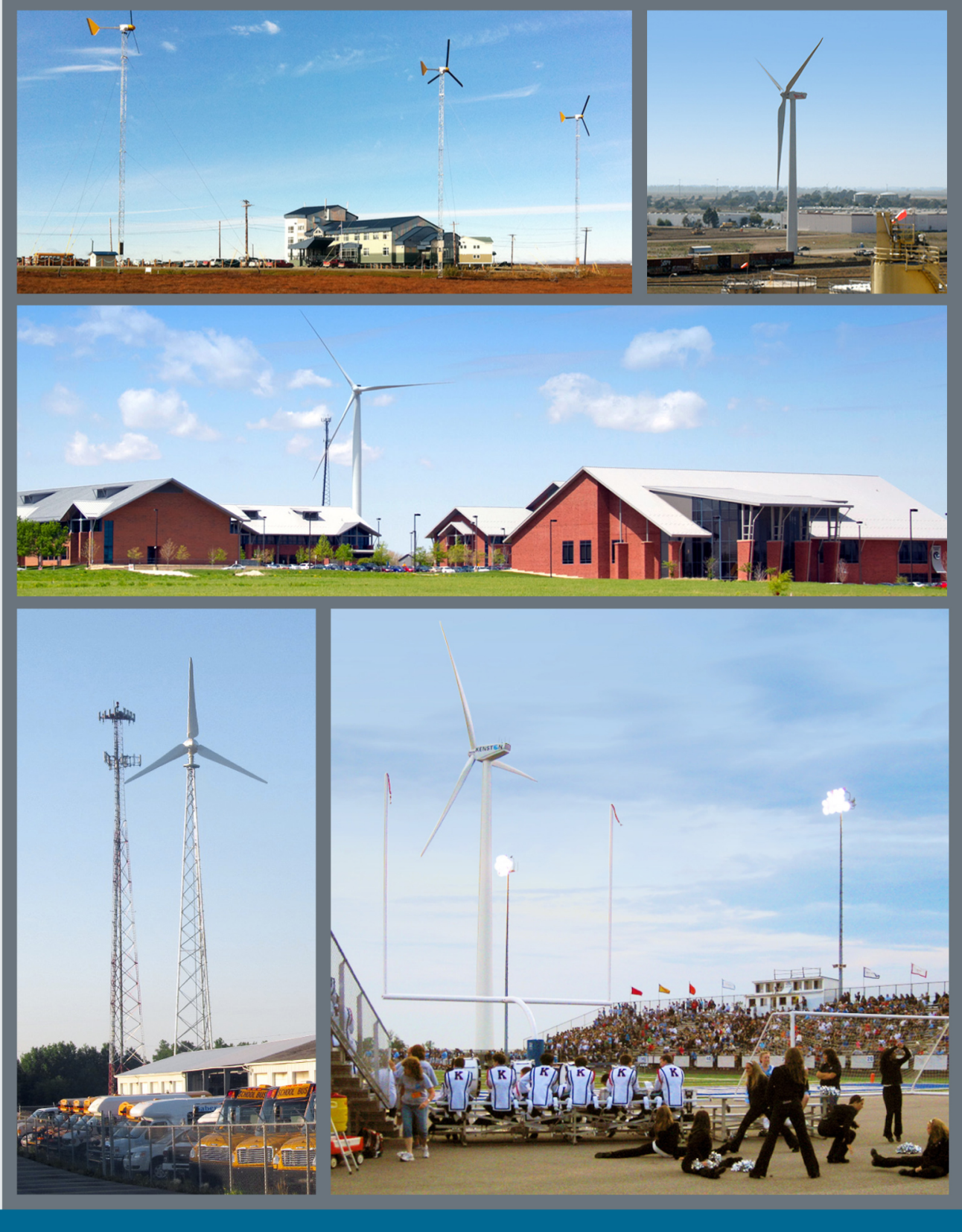


\title{
DISCLAIMER
}

This report was prepared as an account of work sponsored by an agency of the United States Government. Neither the United States Government nor any agency thereof, nor Battelle Memorial Institute, nor any of their employees, makes any warranty, express or implied, or assumes any legal liability or responsibility for the accuracy, completeness, or usefulness of any information, apparatus, product, or process disclosed, or represents that its use would not infringe privately owned rights. Reference herein to any specific commercial product, process, or service by trade name, trademark, manufacturer, or otherwise does not necessarily constitute or imply its endorsement, recommendation, or favoring by the United States Government or any agency thereof, or Battelle Memorial Institute. The views and opinions of authors expressed herein do not necessarily state or reflect those of the United States Government or any agency thereof.

This report is being disseminated by the U.S. Department of Energy. As such, this document was prepared in compliance with Section 515 of the Treasury and General Government Appropriations Act for Fiscal Year 2001 (Public Law 106-554) and information quality guidelines issued by the U.S. Department of Energy. Though this report does not constitute "influential" information, as that term is defined in the U.S. Department of Energy's Information Quality Guidelines or the Office of Management and Budget's Information Quality Bulletin for Peer Review, the study was reviewed both internally and externally prior to publication for purposes of external review and the study benefited from the advice and comments from a dozen individuals representing wind industry consulting firms, state agencies, wind turbine manufacturers, and other federal laboratories.

\author{
PACIFIC NORTHWEST NATIONAL LABORATORY \\ operated by \\ BATTELLE \\ for the \\ UNITED STATES DEPARTMENT OF ENERGY \\ under Contract DE-AC05-76RL01830
}

Printed in the United States of America

Available to DOE and DOE contractors from the Office of Scientific and Technical Information, P.O. Box 62, Oak Ridge, TN 37831-0062;

ph: (865) 576-8401

fax: (865) 576-5728

email: reports@adonis.osti.gov

Available to the public from the National Technical Information Service

5301 Shawnee Rd., Alexandria, VA 22312

ph: (800) 553-NTIS (6847)

email: orders@ntis.gov <http://www.ntis.gov/about/form.aspx>

Online ordering: http://www.ntis.gov 


\title{
2012 Market Report on U.S. Wind Technologies in Distributed Applications
}

\author{
AC Orrell \\ HE Rhoads-Weaver ${ }^{1}$ \\ LT Flowers ${ }^{2}$ \\ JO Jenkins ${ }^{3}$ \\ MN Gagne ${ }^{1}$ \\ $\mathrm{KM} \mathrm{Sahl}^{1}$ \\ BH Pro ${ }^{1}$ \\ RE Baranowski ${ }^{1}$
}

August 2013

Prepared for

the U.S. Department of Energy

under Contract DE-AC05-76RL01830

Pacific Northwest National Laboratory

Richland, Washington 99352

\footnotetext{
${ }^{1}$ eFormative Options, Vashon, Washington

${ }^{2}$ American Wind Energy Association, Washington, D.C.

${ }^{3}$ Distributed Wind Energy Association, Flagstaff, Arizona
} 



\section{Executive Summary}

At the end of 2012, U.S. wind turbines in distributed applications reached a 10 -year cumulative installed capacity of more than $812 \mathrm{MW}$ from more than 69,000 units across all 50 states. In 2012 alone, nearly 3,800 wind turbines totaling $175 \mathrm{MW}$ of distributed wind capacity were documented in 40 states and in the U.S. Virgin Islands, with $138 \mathrm{MW}$ using utility-scale turbines (i.e., greater than $1 \mathrm{MW}$ in size), $19 \mathrm{MW}$ using mid-size turbines (i.e., $101 \mathrm{~kW}$ to $1 \mathrm{MW}$ in size), and 18.4 MW using small turbines (i.e., up through $100 \mathrm{~kW}$ in size).

Distributed wind is defined in terms of technology application based on a wind project's location relative to end-use and power-distribution infrastructure, rather than on technology size or project size. Distributed wind systems are connected either on the customer side of the meter (to meet the onsite load) or directly to the local grid (to support grid operations or offset large loads nearby).

Capacity-weighted average costs reported for a sample of 2012 U.S. distributed wind installations were $\$ 2,540 / \mathrm{kW}$ for utility-scale wind turbines, $\$ 2,810 / \mathrm{kW}$ for mid-sized wind turbines, and $\$ 6,960 / \mathrm{kW}$ for newly manufactured (domestic and imported) small wind turbines. An emerging trend observed in 2012 was an increased use of refurbished turbines. The reported capacity-weighted average cost of refurbished small wind turbines installed in 2012 was $\$ 4,080 / \mathrm{kW}$.

As a result of multiple projects using utility-scale turbines, Iowa deployed the most new overall distributed wind capacity, $37 \mathrm{MW}$, in 2012. Nevada deployed the most small wind capacity in 2012, with nearly $8 \mathrm{MW}$ of small wind turbines installed in distributed applications. In the case of mid-size turbines, Ohio led all states in 2012 with 4.9 MW installed in distributed applications.

As in previous years, state and federal policies and incentives continued to play a substantial role in the development of distributed wind projects. In 2012, U.S. Treasury Section 1603 payments and grants and loans from the U.S. Department of Agriculture's Rural Energy for America Program were the main sources of federal funding for distributed wind projects. State and local funding varied across the country, from rebates to loans, tax credits, and other incentives.

Reducing utility bills and hedging against potentially rising electricity rates remain drivers of distributed wind installations. In 2012, other drivers included taking advantage of the expiring U.S. Treasury Section 1603 program and a prosperous year for farmers. While 2012 saw a large addition of distributed wind capacity, considerable barriers and challenges remain, such as a weak domestic economy, inconsistent state incentives, and very competitive solar photovoltaic and natural gas prices.

The distributed wind industry remains committed to improving the marketplace by advancing third-party certification of wind turbines and introducing alternative financing models, such as third-party power purchase agreements and lease-to-own agreements more typical in the solar photovoltaic market. Continued growth is expected in 2013. 


\section{Acknowledgments}

The authors wish to thank the following people for their help in producing this report: Jonathan Bartlett, Liz Hartman, Mark Higgins, and Michael Derby of the U.S. Department of Energy's Wind and Water Power Technologies Office (WWPTO) and Bret Barker (New West Technologies in support of WWPTO).

Emily Williams, Elizabeth Salerno, and the American Wind Energy Association for the use of their wind power project database.

Mike Parker, Christopher DeGraaf, Franny White, and Brie Van Cleve of Pacific Northwest National Laboratory for their internal review, editing, and graphic design.

The authors wish to thank the following people for their review and/or contributions to this report: Tony Crooks, Ricardo Colon, Chris Cassidy and Lisa Siesennop (USDA Rural Development); Stephanie Savage, Tony Jimenez, Julie Jones, Rick Damiani, and Suzanne Tegen (National Renewable Energy Laboratory); Mike Bergey, Scott Merrick (Bergey Windpower); Andrew Kruse, Randeep Dosanjh, Charles Newcomb, Shawn Boudreau, Brian Hanson, Andrew Young (Endurance Wind Power); Bryan Mornaghi (Northern Power); Mark Bolinger, Ryan Wiser (Lawrence Berkeley National Laboratory); Chelsea Barnes (North Carolina Solar Center); Larry Sherwood (Sherwood \& Associates); Trudy Forsyth (Wind Advisors); Tom Wind (Wind Utility Consulting); Paul Rekow (Iowa Small Wind Advocate); Tom Gray (American Wind Energy Association); Lisa Daniels (Windustry).

The authors wish to thank the following companies and organizations for contributing data and information for this report: ACME Wind Turbines, Ark Alloy; Aegis Wind; Ampair; Bridgewell; Cleanfield Energy; Dyocore; Eclectic Energy; Enertech; enXco Service Corporation; Evance Wind; EWT International; Gaia-Wind; Gamesa; Harvest The Wind Network; Home Energy USA; Juhl Wind; Kestrel Wind Turbines; Kingspan; Milbank; Polaris; Powerworks Wind Turbines; Renewegy; Seaforth; Sonkyo Energy; Southwest Windpower; Sustainable Energy Developments; Talk Inc.; Urban Green Energy; Ventera; Vergnet; Wind Energy Solutions, Renewable Northwest Project; Wind Turbine Industries; Xzeres.

The authors wish to thank the following state and federal agencies for contributing data and information for this report: U.S. Treasury, Ruth Douglas Miller (Kansas State University); Kerry Campbell (Pennsylvania Department of Environmental Protection); Julian Dash (Rhode Island Economic Development Corporation); Ian Burnes (Efficiency Maine); Peter McPhee (Massachusetts CEC); Lise Trudeau (Minnesota Department of Commerce); Bob Leker (North Carolina Commerce); Chris Dearth (Energy Trust of Oregon); Matthew Brown (Tennessee Valley Authority); Bill Willis (West Virginia Energy Office); John Pearce (Iowa Utilities Board); Keith Kutz (Iowa Energy Center); Rich Stromberg (Alaska Energy Authority); Sarah Taheri and James Lee (California Energy Commission); Dave Ljungquist (Connecticut Clean Energy Fund); Wayne Hartel (Illinois Department of Commerce); Andrew Gohn (Maryland Energy Administration); Brian DeKiep (Montana Public Service Commission); Jack Osterman (Nebraska State Energy Office); Matt Newberry (NV Energy); Benjamin Hunter (New Jersey Board of Public Utilities); Mark Mayhew (New York State Energy Research \& Development); Mark Gundelfinger (AEP - Ohio); Trish Jerman (South Carolina Energy Office); Andrew Perchlik (Vermont Clean Energy Development Fund); Phil Lou (Washington State University Energy Program); Sherry Hughes (Wyoming State Energy Office); Kristofor Anderson (Georgia Division of Energy Resources); Ken Jurman (Virginia Department of Mines, Minerals and Energy); Rich Hasselman (formerly Focus on Energy).

The authors would like to thank these companies and agencies for their support of this report: BerMc Controls; Cascade Community Wind; Eocycle Technologies; FloDesign Wind Turbines; Gazelle; Obeki; Green Energy Technologies; Indiana Office of Energy Development; Michigan Energy Office; New Mexico Public Regulation Commission; Oklahoma Department of Commerce; Pika Energy; Texas State Energy Conservation Office; Western Illinois University. 


\section{Acronyms and Abbreviations}

\begin{tabular}{|c|c|}
\hline $\mathrm{CDE}$ & Community Development Entity \\
\hline $\mathrm{COE}$ & cost of energy \\
\hline DES & distributed energy storage \\
\hline DOE & U.S. Department of Energy \\
\hline DSIRE & Database of State Incentives for Renewables and Efficiency \\
\hline DWEA & Distributed Wind Energy Association \\
\hline EERE & Energy Efficiency and Renewable Energy \\
\hline FIT & feed-in-tariff \\
\hline FWS & U.S. Fish and Wildlife Service \\
\hline GE & General Electric \\
\hline HAWT & horizontal-axis wind turbine \\
\hline IPP & independent power producer \\
\hline IREC & Interstate Renewable Energy Council \\
\hline IRS & U.S. Internal Revenue Service \\
\hline ITAC & Interstate Turbine Advisory Council \\
\hline ITC & Investment Tax Credit \\
\hline JEDI & Jobs and Economic Development Impact \\
\hline $\mathrm{kW}$ & kilowatt \\
\hline $\mathrm{m}$ & meter \\
\hline MLP & Master Limited Partnership \\
\hline MW & megawatt \\
\hline NMTC & New Markets Tax Credit \\
\hline NREL & National Renewable Energy Laboratory \\
\hline NYSERDA & New York State Energy Research and Development Authority \\
\hline O\&M & operations and maintenance \\
\hline PPA & power purchase agreement \\
\hline PTC & Production Tax Credit \\
\hline PURPA & Public Utility Regulatory Policies Act \\
\hline PV & photovoltaics \\
\hline QECB & Qualified Energy Conservation Bond \\
\hline QEI & Qualified Equity Investment \\
\hline REIT & Real Estate Investment Trust \\
\hline RPS & renewable portfolio standard \\
\hline RTC & regional test center \\
\hline SREC & Solar Renewable Energy Certificate \\
\hline SWAT & Small Wind Association of Testers \\
\hline SWCC & Small Wind Certification Council \\
\hline USDA & U.S. Department of Agriculture \\
\hline VAWT & vertical-axis wind turbine \\
\hline $\mathrm{W}$ & watt \\
\hline WAC & Wind Application Center \\
\hline WWPTO & Wind and Water Power Technologies Office \\
\hline
\end{tabular}




\section{Contents}

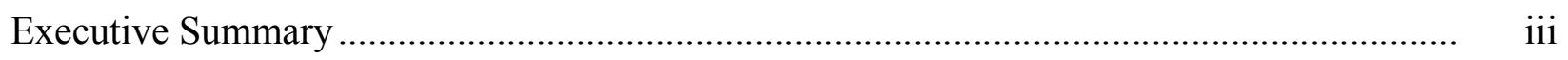

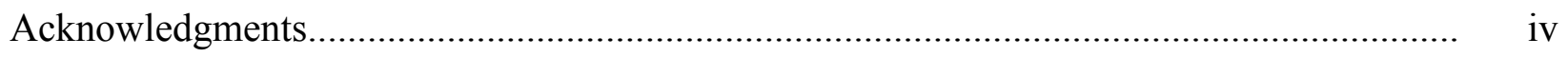

Acronyms and Abbreviations ……………………................................................... v

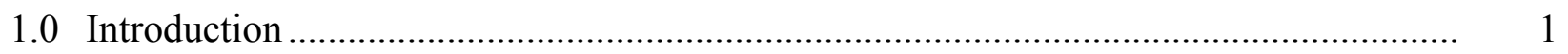

2.0 U.S. Distributed Wind Market Overview and Highlights.............................................. 2

3.0 Small Wind Turbine Market (up through $100 \mathrm{~kW}$ )......................................................... 11

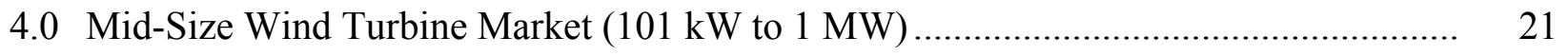

5.0 Utility-Scale Wind Turbine Market (Larger than $1 \mathrm{MW}$ )............................................. 26

6.0 Federal and State Incentives and Policies ………........................................................ 31

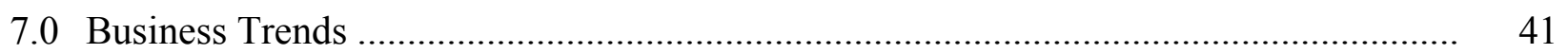

8.0 Developments, Drivers, and Barriers .................................................................... 50

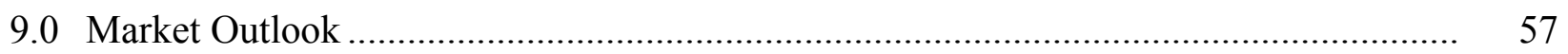

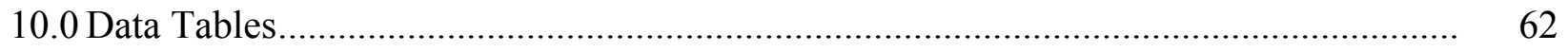

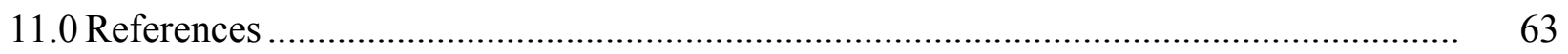

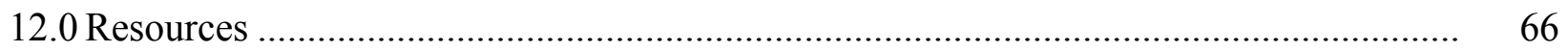

\section{Figures}

$1 \quad$ U.S. Distributed Wind Capacity by Turbine Type ............................................................ 2

2 Wind Turbine Sales (units) in 2003-2012 ……….......................................................... 3

3 Wind Turbine Sales (units) in (a) 2011 and (b) 2012 ................................................. 3

4 Types of Turbines and Towers Used in 2012 U.S. Distributed Wind Applications ........ 5

5 Distributed Wind Capacity by Type and Average Turbine Size ...................................... 6

62012 U.S. Distributed Wind Capacity Additions ................................................................ 6

7 2003-2012 Cumulative U.S. Distributed Wind Capacity ..................................................... 7

8 Top States for Distributed Wind Capacity, 2003-2012 ……………………………...... 8

9 Average Installed Costs for All Turbine Types................................................................ 9

10 U.S. Small Wind Turbine Sales by Market Segment, 2007-2012 .................................. 11

11 U.S. Small Wind Domestic, Imports, and Export Sales, 2003-2012 ……..................... 12

12 U.S. Small Wind Capacity and Unit Trends, 2007-2012 ………………….................. 13

13 U.S. Small Wind Capacity Top States, 2003-2012 …………………………….......... 15

142012 U.S. Small Wind Capacity Additions.................................................................... 15

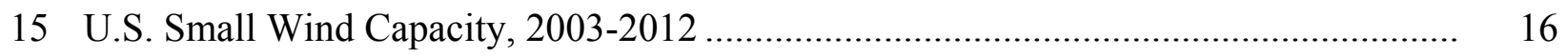


16 U.S. Small Wind Manufacturer Sales........................................................................... 16

17 U.S. Small Wind Turbines Average Installed Cost by Type, 2011-2012 ………........... 19

182012 U.S. Small Wind Turbines Average Installed Cost by Size .................................... 19

19 U.S. Mid-Size Distributed Wind Capacity Top States, 2003-2012 ……………............. 23

202012 U.S. Mid-Size Wind Capacity Additions ............................................................. 23

21 U.S. Mid-Size Wind Capacity, 2003-2012 …………................................................... 24

22 Average Installed Cost of Mid-Size Turbines in Distributed Applications, 2011-2012 .. 25

23 U.S. Utility-Scale Distributed Wind Capacity, Top States, 2003-2012 …….................. 27

242012 U.S. Utility-Scale Distributed Wind Capacity Additions........................................ 28

25 U.S. Utility-Scale Distributed Wind Capacity, 2003-2012 ……………………........... 28

26 Utility-Scale Turbines in Distributed Applications Average Installed Cost, 20112012

272012 U.S. Distributed Wind Federal and State/Local Funding Awards ......................... 31

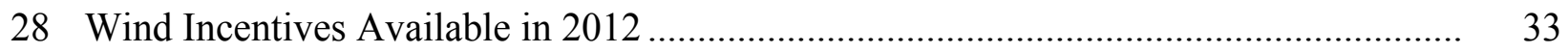

29 8-MW Junction Hilltop Wind Project in Iowa ............................................................ 35

30 Net Metering State Policies .................................................................................. 37

31 Residential-Scale $30 \mathrm{~m}$ Wind Map .............................................................................. $\quad 50$

\section{Tables}

$1 \quad$ U.S. Distributed Wind Capacity Additions in 2012 …..................................................... 7

2 Top Supplier Countries for 2012 Installed MW in U.S. Distributed Wind

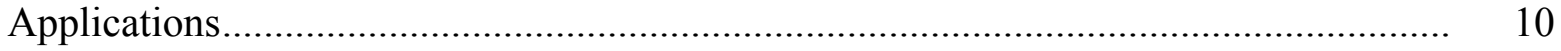

3 U.S. Small Wind Capacity Additions in 2012 ....................................................... 14

4 U.S. Mid-Size Distributed Wind Capacity Additions in 2012 ………………….......... 22

$5 \quad$ U.S. Utility-Scale Distributed Wind Capacity Additions in 2012 .................................. 27

6 Small Wind Turbine Certification Ratings Issued or Renewed in 2012 ........................ 44

7 Preliminary Small Wind Annual O\&M Cost Assumptions Used in JEDI ...................... 55

8 Megawatts By Year By Sector .................................................................................. 62

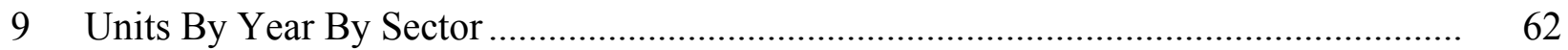

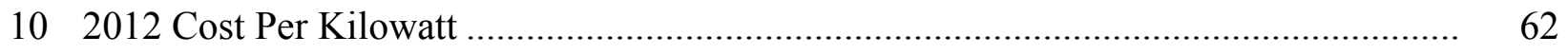

112012 Application Type ........................................................................................... 62 



\subsection{Introduction}

Distributed wind energy systems are commonly, but not always, installed on residential, agricultural, commercial, industrial, and community sites and can range in size from a fewhundred-watt, off-grid turbine at a remote cabin or a $5-\mathrm{kW}$ turbine at a home to a multi-MW turbine at a manufacturing facility.

Distributed wind energy systems are connected either on the customer side of the meter (to meet the onsite load) or directly to the local distribution or micro grid (to support grid operations or offset large loads nearby). This distinction differentiates distributed wind power from wholesale power generated at large wind farms and sent via transmission lines to substations for subsequent distribution to loads.

The U.S. Department of Energy (DOE) Energy Efficiency and Renewable Energy (EERE) Wind and Water Power Technologies Office defines distributed wind in terms of technology application based on a wind project's location relative to end-use and power-distribution infrastructure, rather than on technology size or project size (Wind Program 2013); thus, the distributed wind market includes turbines and projects of many sizes. Wind systems are characterized as distributed based on the following criteria:

- Proximity to end-use: wind turbines installed at or near the point of end-use for the purposes of meeting onsite load or supporting the operation of the local (distribution or micro) grid.

- Point of interconnection: wind turbines connected on the customer side of the meter or directly to the local grid. ${ }^{1}$

Therefore the scope of this report has been expanded from past years' reports to include a finer breakdown of small wind statistics (i.e., up through $100 \mathrm{~kW}$ in size), more extensive statistics on mid-size turbines (i.e., $101 \mathrm{~kW}$ to $1 \mathrm{MW}$ in size) used in distributed applications, and new statistics on utility-scale turbines (i.e., greater than $1 \mathrm{MW}$ in size) used in distributed applications. Past years' reports only focused on small wind turbines; thus, this report makes use of more historical data for the small wind market than it does for the mid-size and utility-scale distributed wind markets.

\footnotetext{
${ }^{1}$ For the purposes of this report, the local grid is defined as distribution lines with interconnected electric load(s).
} 


\subsection{U.S. Distributed Wind Market Overview and Highlights}

At the end of 2012, U.S. wind turbines in distributed applications reached a 10 -year cumulative installed capacity of more than $812 \mathrm{MW}$ (Figure 1) from more than 69,000 units across all 50 states.

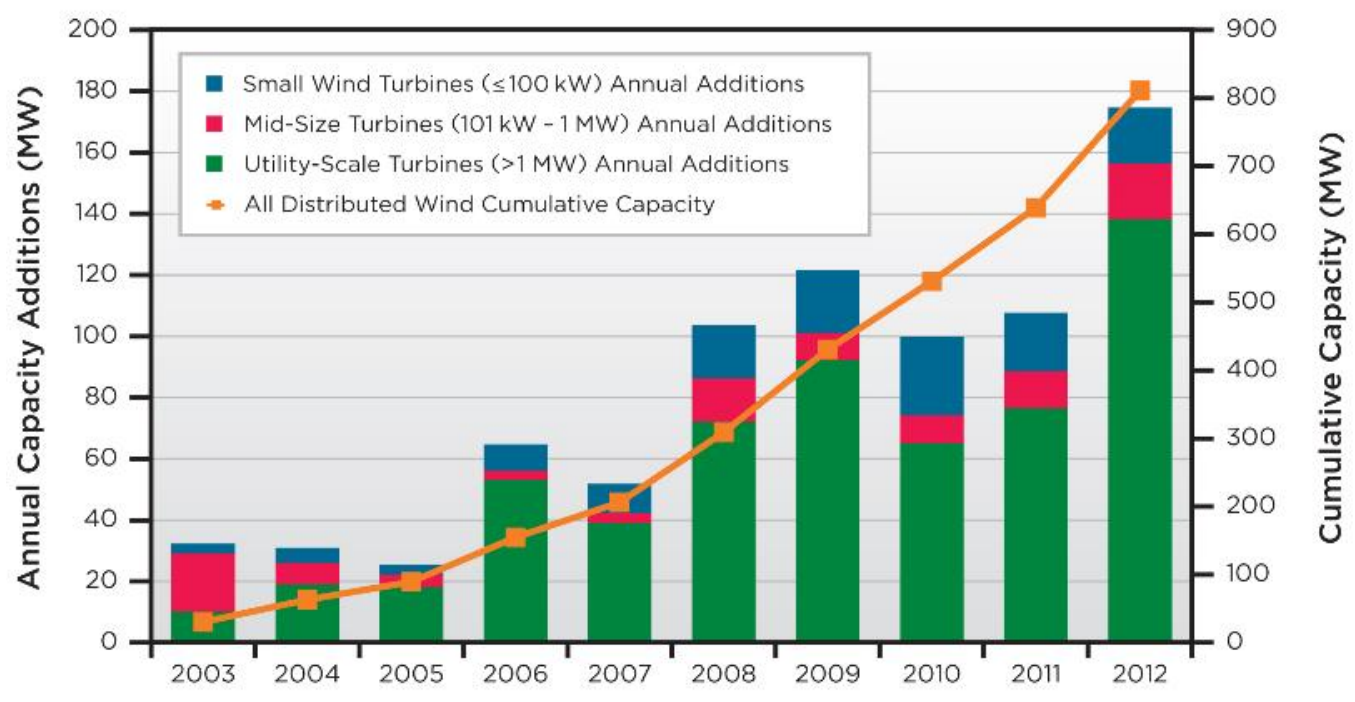

Figure 1. U.S. Distributed Wind Capacity by Turbine Type

\subsection{Overview of Distributed Wind Market Segments}

Although sales of small wind turbines declined in 2012, distributed wind installations still comprise more than $68 \%$ of all wind turbines installed in the United States (on a unit basis) over the past 10 years $(2003-2012)$, and small wind systems still make up the majority of turbine units used in distributed applications (Figure 2). In 2012, the majority of distributed wind projects installed consisted of single turbines, and the largest project installed consisted of six turbines.

Off-grid small wind turbine models continue to account for the bulk of wind turbine units installed in U.S. distributed wind applications. In 2012, almost $72 \%$ of turbines in distributed wind projects were installed to power remote homes, telecommunications facilities, rural electricity and water supply, and military sites.

Wind turbines connected to the distribution grid, or "grid-tied" applications, comprised more than $99 \%$ of the annual domestic distributed wind capacity (in terms of MW), with more than $66 \%$ either installed on the customer side of the meter at residences, farms, schools, and businesses; in net metering and net billing arrangements; or otherwise meeting onsite demand across 40 states, primarily in the Midwest, New England, and California. The remaining 2012 grid-tied distributed wind projects, accounting for $27 \%$ of the mid-size and $36 \%$ of the utilityscale distributed wind capacity, were connected to distribution lines serving local loads and constructed primarily in Iowa-with one project each in Vermont, California, Washington, and Illinois. 


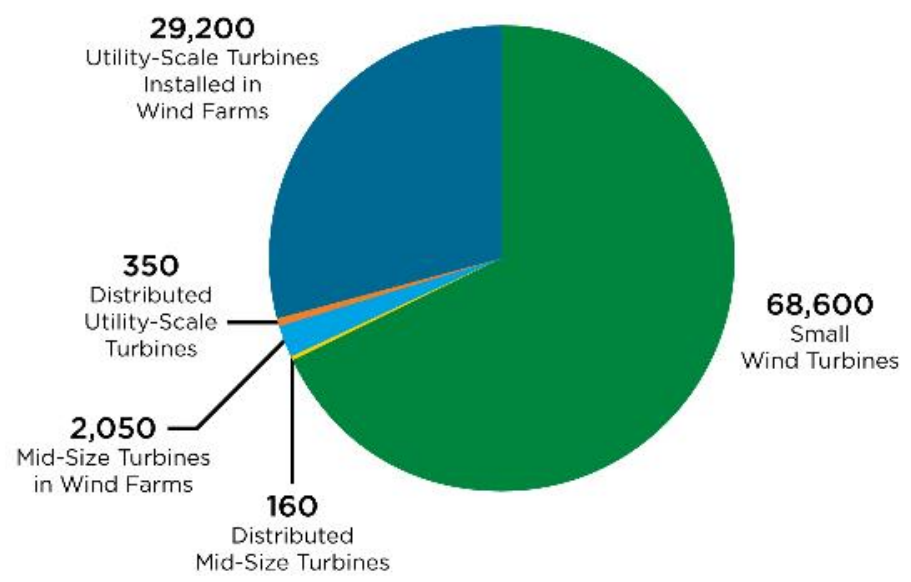

Figure 2. Wind Turbine Sales (units) in 2003-2012

\subsection{Annual U.S. Distributed Wind Deployment}

In 2012, the annual capacity of distributed wind installed in the United States increased by $62 \%$ over that of 2011 with $175 \mathrm{MW}$ deployed. Additions in 2012 account for about 3,800 wind turbines and represent more than $\$ 410$ million in domestic investment. ${ }^{2}$ Corresponding to a large decrease in off-grid and residential-scale units sold, the number of small wind turbine units installed in 2012 U.S. distributed wind applications dropped by nearly 50\% from 2011 . Over the same period, the number of mid-size wind turbines installed in the U.S. increased by more than $250 \%$ and the number of utility-scale wind turbines increased by nearly $100 \%$, leading to a sharp decline in the contribution of small wind turbines to the overall U.S. wind market. Small wind turbines dropped from nearly $70 \%$ of all U.S. wind units installed in 2011 (Figure 3a) to less than $40 \%$ of units installed in 2012 (Figure $3 \mathrm{~b}$ ). For context, utility-scale turbines installed in wind farms - non-distributed applications - are also shown in Figures 2 and 3.
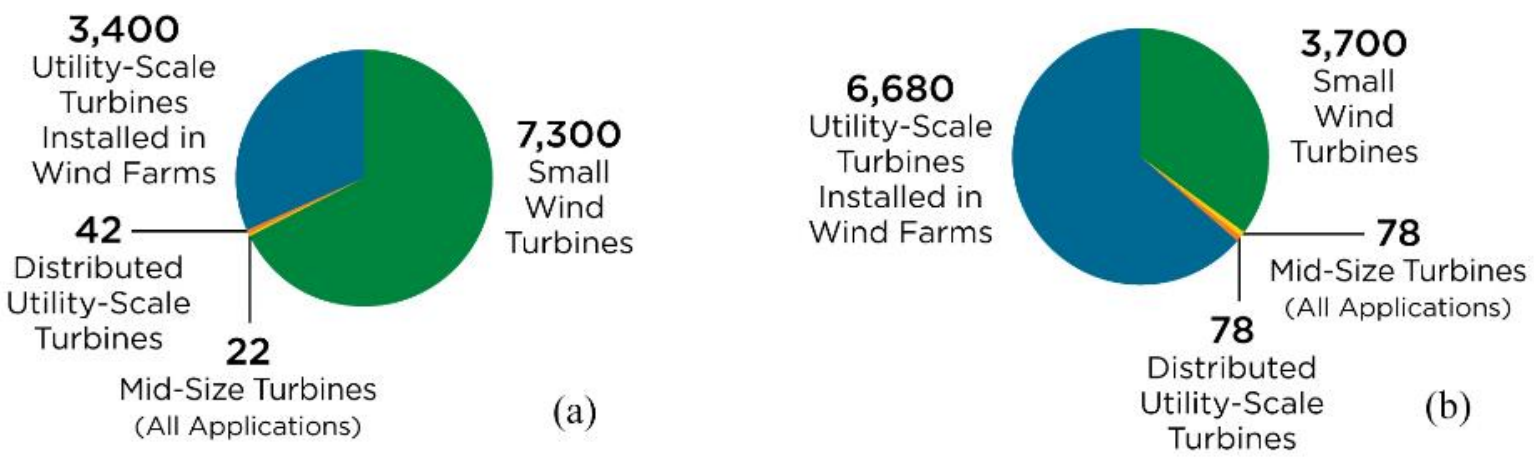

Figure 3. Wind Turbine Sales (units) in (a) 2011 and (b) 2012

\footnotetext{
${ }^{2}$ Details for the turbine units and capacity numbers presented in this report are shown in Section 10. Some numbers presented vary slightly due to rounding.
} 
Utility-scale wind turbines (i.e., above $1 \mathrm{MW}$ ) installed in distributed applications showed the largest increase - an 80\% increase from $77 \mathrm{MW}$ in 2011 to $138 \mathrm{MW}$ in 2012. The next largest increase was in mid-size wind turbines (i.e., $101-1,000 \mathrm{~kW}$ ), which increased more than 50\% from $12 \mathrm{MW}$ in 2011 to $19 \mathrm{MW}$ in 2012. Newly manufactured mid-size and utility-scale wind turbines installed in distributed wind applications (excluding refurbished equipment) increased 81\%, from $85 \mathrm{MW}$ in 2011 to $154 \mathrm{MW}$ in 2012.

Sales of newly manufactured small wind turbines (i.e., up through $100 \mathrm{~kW}$ ) installed in the United States decreased by 53\% from about 19 MW in 2011 to 8.9 MW in 2012. Seven U.S.based suppliers of newly manufactured and refurbished small wind turbines (i.e., reconditioned equipment emerging primarily from California wind farm repowering) reported sales greater than $1 \mathrm{MW}$, up from four suppliers in 2011. The combined U.S. market for new and refurbished small wind turbines declined by 3\% from $19 \mathrm{MW}$ in 2011 to $18.4 \mathrm{MW}$ in 2012, representing $\$ 101$ million in investment and nearly 3,700 units sold.

\subsubsection{Types of Turbines and Towers}

In 2012, reported U.S. distributed wind deployments encompassed 84 different wind turbine models ranging from $100 \mathrm{~W}$ to $3 \mathrm{MW}^{3}$ from 55 suppliers with a U.S. sales presence (Figure 4), including suppliers from Asia (i.e., China, Japan, South Korea, and India), Europe (i.e., UK, Belgium, Denmark, France, Germany, Netherlands, and Spain), Canada, and South Africa. U.S. manufacturers based in 14 states (i.e., Arizona, California, Georgia, Kansas, Massachusetts, Michigan, Minnesota, Missouri, New York, Oklahoma, Oregon, Vermont, Washington, and Wisconsin) sold 38 different models. Nine of the top 10 models of all 2012 wind turbines installed in distributed applications (on a unit basis) were manufactured in the United States.

The widest variety of wind turbine and tower designs are for turbines rated under $20 \mathrm{~kW}$. Only a few turbines larger than $10 \mathrm{~kW}$ are not configured as 3-bladed horizontal-axis units installed on self-supporting tubular towers. Self-supporting lattice and guyed monopole towers were reported as the most popular designs for U.S. residential-scale wind turbine models, with vertical-axis and rooftop models representing less than 3\% of 2012 U.S. distributed wind capacity and less than $9 \%$ of units. A wide range of tower designs and heights were sold for small turbine projects, including guyed lattice and monopole (including tilt-up designs ${ }^{4}$ ) and selfsupporting lattice and tubular towers.

Tower heights ranged from as low as $9 \mathrm{~m}$ up to $49 \mathrm{~m}$ for small turbines and from $30 \mathrm{~m}$ to $100 \mathrm{~m}$ for mid-size and multi-MW turbines, with most 2012 grid-tied distributed wind installations featuring hub heights of 30 to $80 \mathrm{~m}$. The capacity-weighted average hub height for all 2011 and 2012 utility-scale distributed wind projects was $82 \mathrm{~m}$. In 2012, the average mid-size distributed wind hub height increased from $53 \mathrm{~m}$ in 2011 to $60 \mathrm{~m}$ and the average hub height for refurbished distributed mid-size turbines increased from $39 \mathrm{~m}$ in 2011 to $52 \mathrm{~m}$.

\footnotetext{
${ }^{3} 1 \mathrm{MW}=1,000 \mathrm{~kW}=1,000,000 \mathrm{~W}$

${ }^{4}$ A tower design with a gin pole attached to allow the turbine to be tilted down and serviced while on the ground.
} 

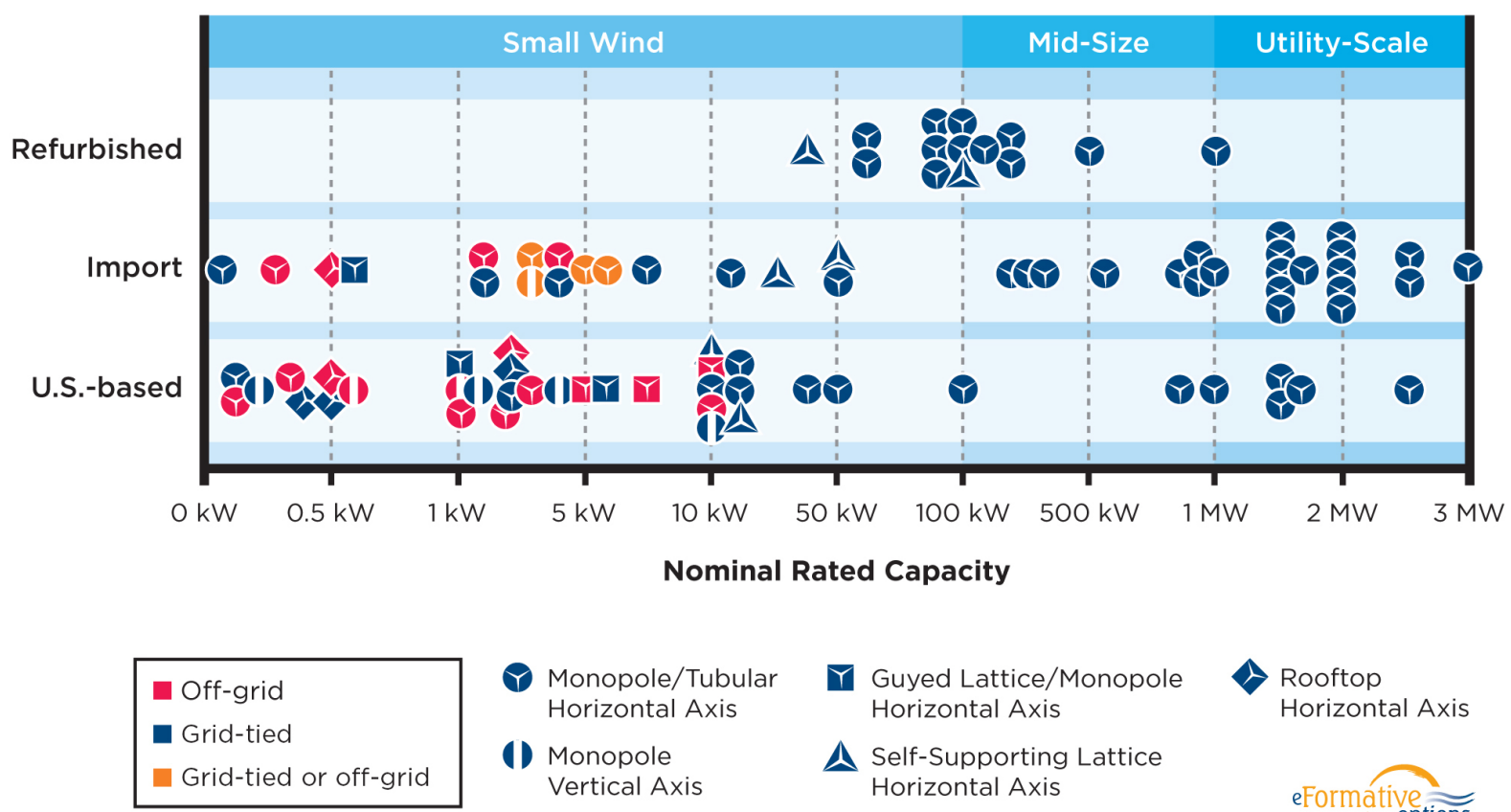
Guyed Lattice/Monopole Horizontal Axis
A Self-Supporting Lattice Horizontal Axis

Rooftop

Horizontal Axis

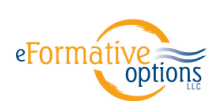

Figure 4. Types of Turbines and Towers Used in 2012 U.S. Distributed Wind Applications

Reflecting the shift in the distributed wind market toward larger "grid-tied" units connected to the distribution grid, the capacity-weighted average size of wind turbines across all distributed wind sectors increased by more than $300 \%$ between 2011 and 2012, from about 15 to $47 \mathrm{~kW}$ (Figure 5). This large increase was primarily due to the $50 \%$ reduction in the number of small wind turbines and the $70 \%$ growth of mid-size and utility-scale turbines in distributed applications.

In addition, the total number of grid-tied wind turbines installed in U.S. distributed applications decreased considerably from more than 3,000 units in 2011 to just over 1,100 grid-tied units in 2012. Off-grid units also declined by about $37 \%$. Grid-tied projects accounted for an increased portion of the overall annual capacity. The average size of grid-tied turbines installed in U.S. distributed applications increased from $35 \mathrm{~kW}$ in 2011 to $156 \mathrm{~kW}$ in 2012, while the average size of off-grid units sold in the United States in 2012 remained stable at about $380 \mathrm{~W}$, continuing the slight decrease from the 2007 off-grid average of $520 \mathrm{~W}$. The dramatic increase in reported installations of refurbished turbines sized $40 \mathrm{~kW}$ to $1 \mathrm{MW}$, from 9 units totaling $3.5 \mathrm{MW}$ in 2011 to 111 units totaling $11.8 \mathrm{MW}$ in 2012 , also contributed to this trend.

\subsubsection{Top Ten States for Distributed Wind: Annual and Cumulative Installations}

Distributed wind installations were documented in 40 states in 2012 (Figure 6), and in all 50 states plus Puerto Rico and the U.S. Virgin Islands over the past 10 years (Figure 7). 


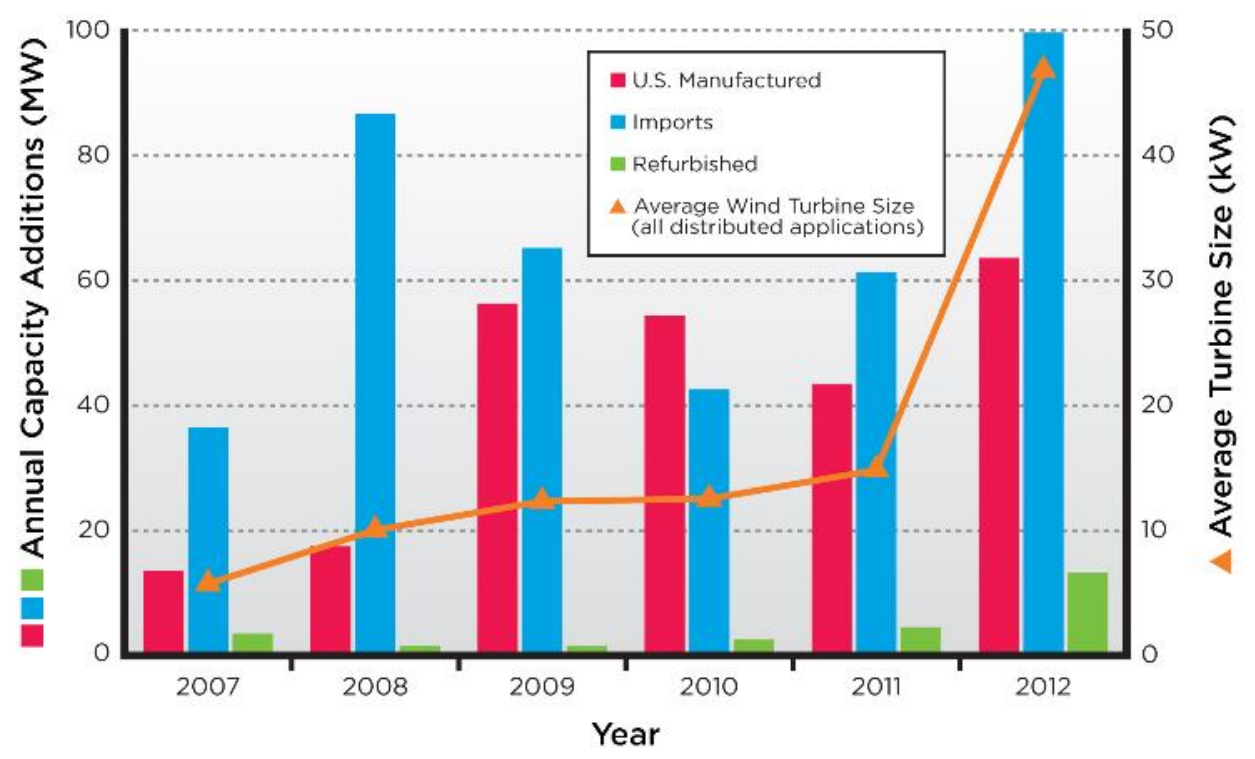

\begin{tabular}{ll|c|c|c|c|c|c|c|}
\hline & & $\mathbf{2 0 0 7}$ & $\mathbf{2 0 0 8}$ & $\mathbf{2 0 0 9}$ & $\mathbf{2 0 1 0}$ & $\mathbf{2 0 1 1}$ & $\mathbf{2 0 1 2}$ \\
\hline Imports (MW) & Small & 1.1 & 4.4 & 3.6 & 4.4 & 3.8 & 2.6 \\
& Mid-Size & 0.0 & 13.0 & 8.3 & 4.8 & 7.2 & 11.7 \\
& Utility & 35 & 69 & 53 & 33 & 50 & 85.2 \\
\hline U.S. Manufactured & Small & 9 & 13 & 17 & 21 & 15 & 6.3 \\
(MW) & Mid-Size & 0 & 0 & 0 & 2 & 2 & 4.3 \\
& Utility & 4 & 4 & 39 & 31 & 26 & 52.7 \\
\hline Refurbished (MW) & Small & 0 & 0 & 0 & 0 & 0 & 9.6 \\
& Mid-Size & 3 & 1 & 1 & 2 & 4 & 3.1 \\
\hline Units & Small & 9.100 & 10,400 & 9.800 & 7.800 & 7.300 & 3.700 \\
(Number of Turbines) & Mid-Size & 9 & 17 & 15 & 22 & 22 & 31 \\
& Utility & 22 & 43 & 63 & 34 & 42 & 78 \\
\hline
\end{tabular}

Figure 5. Distributed Wind Capacity by Type and Average Turbine Size

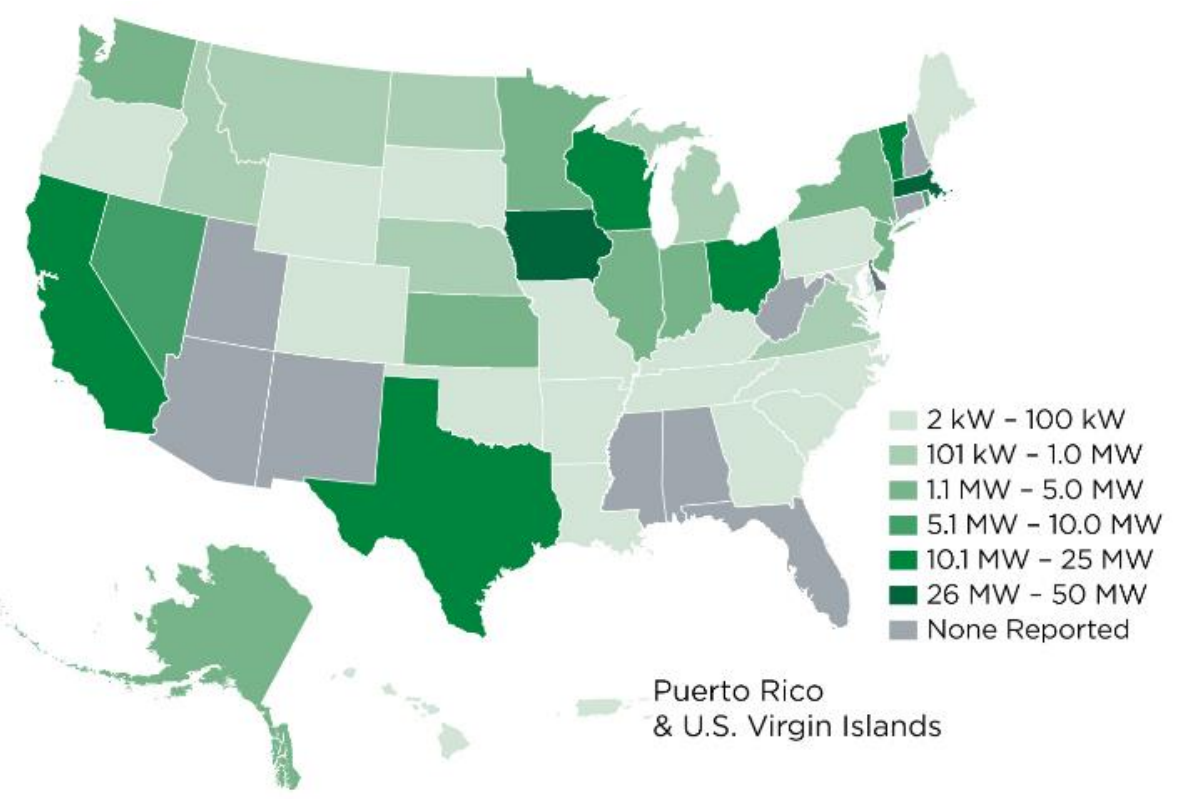

Figure 6. 2012 U.S. Distributed Wind Capacity Additions 


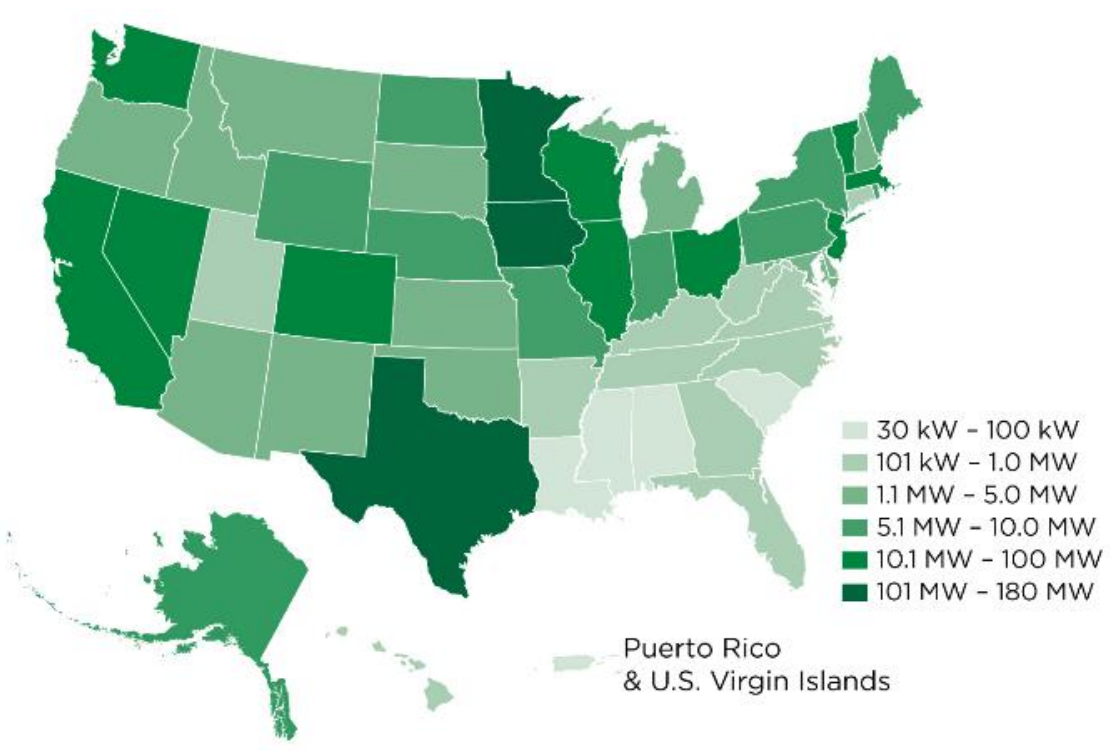

Figure 7. 2003-2012 Cumulative U.S. Distributed Wind Capacity

Iowa, Massachusetts, California, and Wisconsin led the nation for new distributed wind power capacity installations in 2012 across all turbine types (Table 1). Comparing 2012 to 2011 yearend figures, Vermont, Rhode Island, Wisconsin, Nevada, and Massachusetts were the fastest growing states in 10-year cumulative distributed wind capacity (Table 1).

Table 1. U.S. Distributed Wind Capacity Additions in 2012

\begin{tabular}{lclc}
\hline \multicolumn{2}{c}{ Top 10 States } & \multicolumn{2}{c}{ Fastest Growing States } \\
\hline \multicolumn{1}{c}{ State } & MW & \multicolumn{1}{c}{ State } & $\begin{array}{c}\text { 2003-2012 Cumulative } \\
\text { Growth over 2003-2011 (\%) }\end{array}$ \\
\hline Iowa & 37 & Vermont & 659 \\
Massachusetts & 27 & Rhode Island & 241 \\
California & 23 & Wisconsin & 233 \\
Wisconsin & 18 & Nevada & 183 \\
Texas & 12 & Massachusetts & 79 \\
Ohio & 11 & Indiana & 66 \\
Vermont & 10 & Kansas & 61 \\
Nevada & 8 & Virginia & 56 \\
Rhode Island & 7 & Kentucky & 54 \\
Illinois & 5 & California & 53 \\
\hline
\end{tabular}

Iowa deployed the most distributed wind capacity, $37 \mathrm{MW}$, in 2012. Further, Iowa retained its position as the state with the most small wind capacity installed over the past 10 years as well as its third place standing for cumulative distributed wind capacity installed over the past 10 years. Iowa installed considerably more distributed wind capacity in 2012 than historical leaders Minnesota and Texas, but not as much small wind capacity as Nevada which added the most small wind capacity in $2012 .^{5}$

\footnotetext{
${ }^{5}$ See Section 3.4 for more information.
} 
Texas, Minnesota, Iowa, California, and Massachusetts led the states for all cumulative distributed wind installations over the past 10 years; each of these five states now has more than $60 \mathrm{MW}$ of small, mid-size, and utility-scale wind turbines combined in distributed applications (Figure 8). Ohio, Wisconsin, Illinois, Colorado, and Washington now each have more than $10 \mathrm{MW}$ of distributed wind capacity.

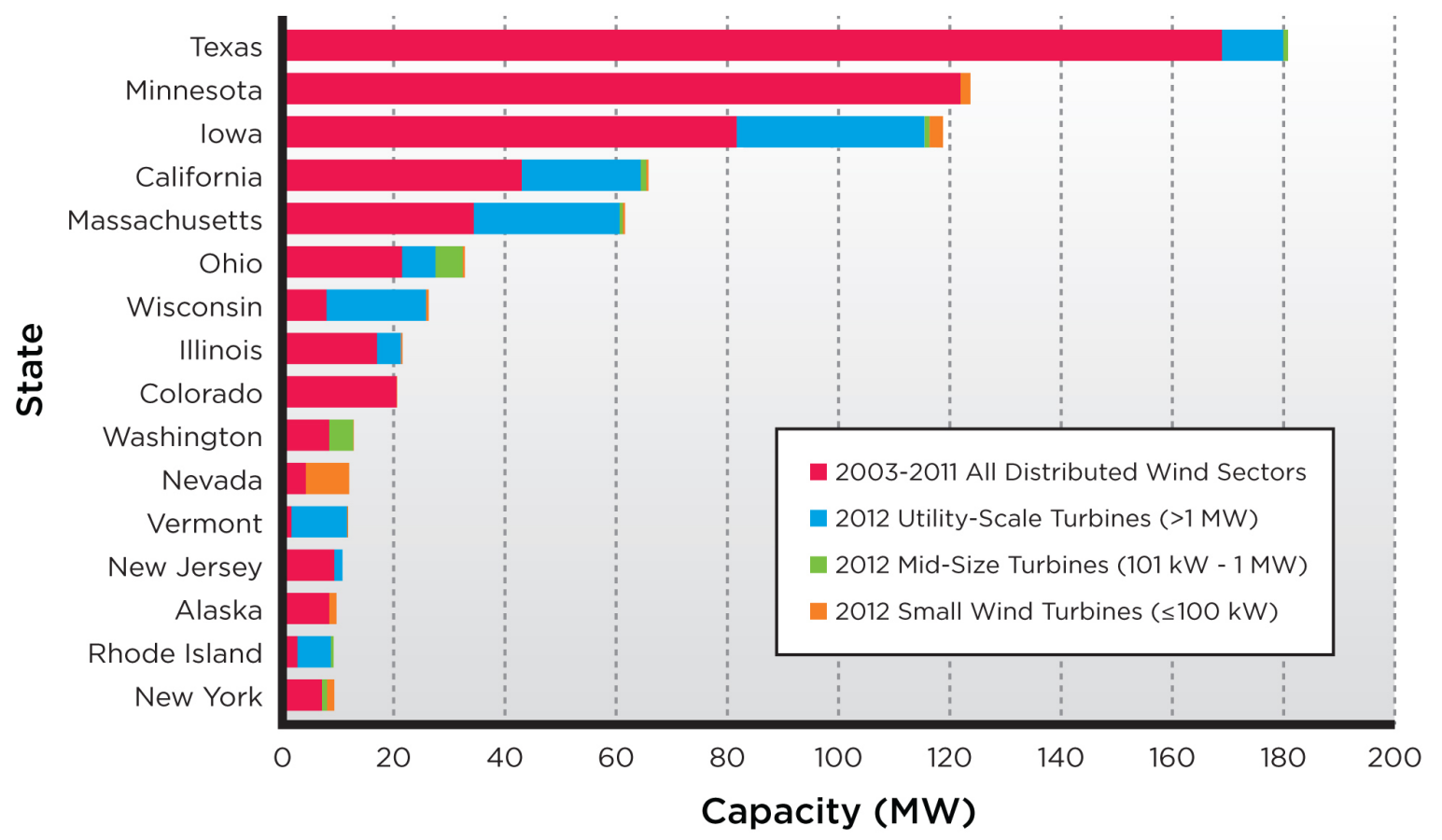

Figure 8. Top States for Distributed Wind Capacity, 2003-2012

\subsubsection{Installed Costs}

Due to substantial differences in costs of various tower types and heights, as well as manufacturer methodology for setting nominal power ratings and estimating installation expenses, reported costs for wind technologies used in 2012 distributed applications ranged widely.

As shown in Figure 9, the reported capacity-weighted average cost to install new small wind turbines (domestic and imported) in the United States in 2012 was $\$ 6,960 / \mathrm{kW}$, based on data for about 3,500 turbines totaling $8.9 \mathrm{MW}$, with a range of $\$ 1,500$ to $\$ 27,500$ per $\mathrm{kW}$. The reported capacity-weighted average installed cost for U.S.-based small wind manufacturers' 2012 sales was $\$ 6,510 / \mathrm{kW}$, based on data for about 3,200 turbines totaling $6.3 \mathrm{MW}, 19 \%$ lower than for non-U.S. suppliers. The reported capacity-weighted average installed cost of refurbished small wind turbines in 2012 was $\$ 4,080 / \mathrm{kW}$, based on data for 105 turbines totaling $9.6 \mathrm{MW}$, with a range of $\$ 3,560$ to $\$ 7,480$ per $\mathrm{kW}$. 


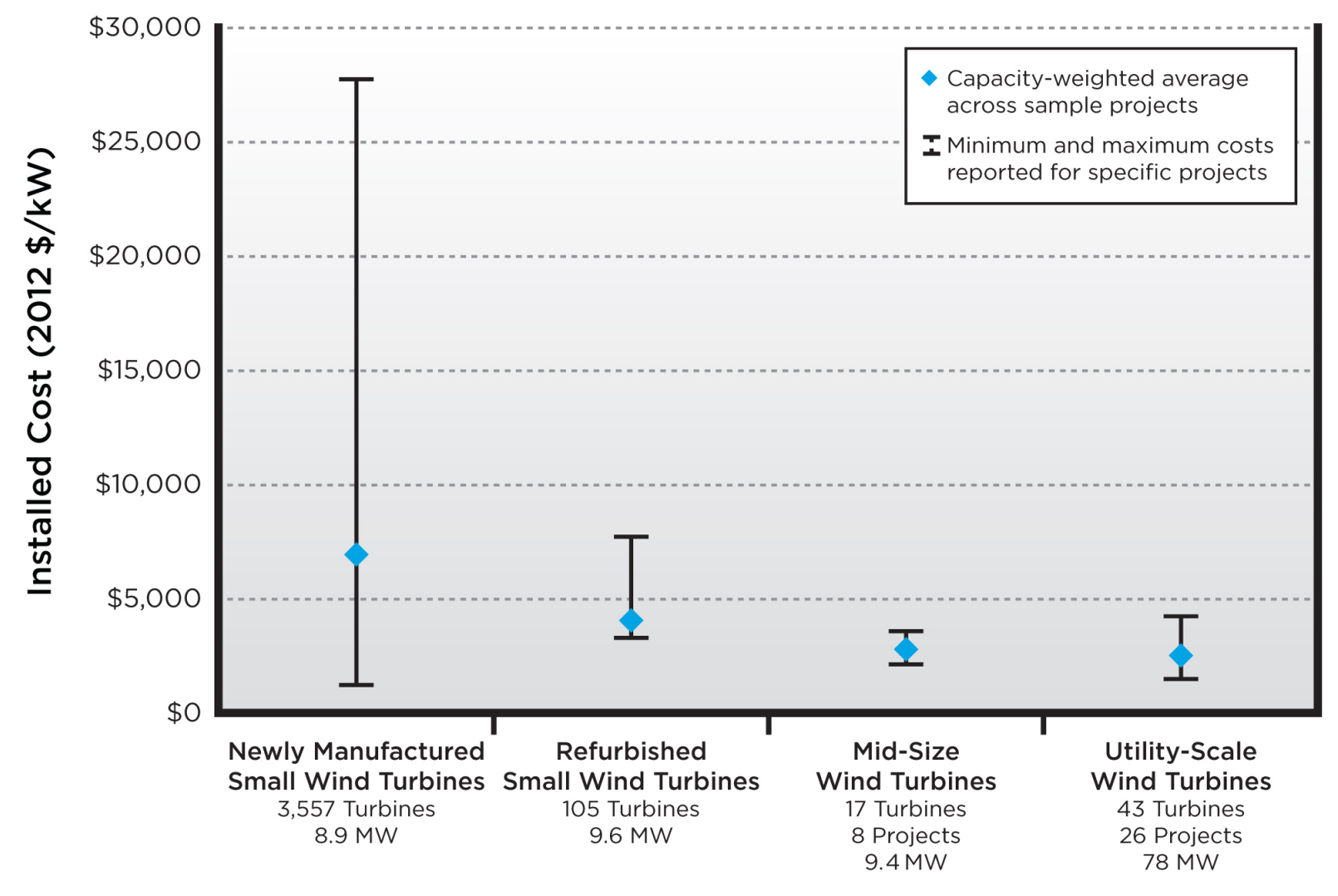

Turbine Size

Figure 9. Average Installed Costs for All Turbine Types ${ }^{6}$

The reported capacity-weighted average installed cost for mid-size wind turbines in 2012 U.S. distributed applications, based on a sample size of 8 projects totaling $9.5 \mathrm{MW}$, was $\$ 2,810 / \mathrm{kW}$, with a range of $\$ 2,400$ to $\$ 3,350$ per $\mathrm{kW}$. The reported capacity-weighted average installed cost for utility-scale wind turbines installed in 2012 U.S. distributed applications, based on a sample size of 26 projects totaling $78 \mathrm{MW}$, was $\$ 2,540 / \mathrm{kW}$, with a range of $\$ 1,760$ to $\$ 4,000$ per $\mathrm{kW}$.

\subsubsection{Top Suppliers and U.S. Manufacturers}

The top U.S. small wind turbine manufacturers in terms of total 2012 sales (domestic and exports) were Southwest Windpower, based in Arizona; Bergey Windpower, based in Oklahoma; and Northern Power Systems, based in Vermont. Leading importers were Endurance Wind Power of Canada and Sonkyo Energy of Spain.

The top suppliers of 2012 mid-size wind turbines installed in U.S. distributed applications were Gamesa of Spain, PowerWind of Germany, and Massachusetts-based Aeronautica.

\footnotetext{
${ }^{6}$ Installed cost values were calculated from U.S. Treasury Section 1603 payments, U.S. Department of Agriculture (USDA) Rural Energy for America Program (REAP) grants, news publications and press releases about projects, state agency reports, and manufacturer sales reports.
} 
The top suppliers of 2012 utility-scale wind turbines installed in U.S. distributed applications were General Electric (GE), with corporate headquarters in the United States; Goldwind of China; and Vestas of Denmark.

\subsection{Imports and Top Supplier Countries}

In 2012, U.S.-based manufacturers claimed nearly $86 \%$ of domestic small wind capacity sales. However, imports comprised more than $60 \%$ of the total (small, mid-size, and utility-scale) annual domestic distributed wind capacity. China alone supplied more than $30 \%$ of distributed utility-scale wind capacity, with five turbine models from five manufacturers, and Denmark supplied more nearly $11 \%$ of total distributed wind capacity. Canada and Spain were the sales leaders in 2012 small wind imports to the United States, with nine models from four manufacturers. Spain also led the mid-size market segment and ranked third in 2012 utility-scale distributed capacity with three additional models.

In 2012, the top 10 supplier countries (based on manufacturer corporate ownership) for U.S. distributed wind applications were based in North America, Europe, and Asia (see Table 2).

Table 2. Top Supplier Countries for 2012 Installed MW in U.S. Distributed Wind Applications

\begin{tabular}{lc}
\hline Country & MW \\
\hline United States & 63 \\
China & 43 \\
Denmark & 19 \\
Spain & 18 \\
Germany & 9.1 \\
South Korea & 4.0 \\
France & 1.8 \\
Canada & 1.7 \\
Japan & 1.0 \\
Netherlands & 0.9 \\
\hline
\end{tabular}




\subsection{Small Wind Turbine Market (up through $100 \mathrm{~kW}$ )}

In 2012, the U.S. market for small wind systems saw 18.4 MW of new capacity in sales, representing nearly 3,700 turbines and \$101 million in investment. Small wind turbines sold in 2012 resulted in cumulative U.S. sales surpassing an estimated $216 \mathrm{MW}$, representing more than 155,000 total units sold since 1980.

On a unit basis, small wind turbines comprised 35\% of all 2012 U.S. wind installations (both in distributed and non-distributed applications). Because most utility-scale wind turbines are installed in multi-turbine wind farms, small wind turbines also comprise $95 \%$ of distinct wind project locations.

\subsection{Number and Types of Projects}

A total of 32 small wind turbine suppliers with a U.S. sales presence, including suppliers based in the United States, Europe, Canada, and South Africa, reported 2012 sales of 74 wind turbine models worldwide (57 models in the United States); $24 \%$ of these models are rated less than $1 \mathrm{~kW}, 46 \%$ are rated 1 to $10 \mathrm{~kW}$, and $30 \%$ are rated $11 \mathrm{~kW}$ to $100 \mathrm{~kW}$ (including 7 refurbished models). These 32 suppliers reported total worldwide sales of $\$ 363$ million, representing more than 11,000 units and $54 \mathrm{MW}$ in 2012.

Compared to 2011 sales, 2012 U.S. small wind capacity additions decreased by $3 \%$ and revenues declined by $12 \%$, representing a $50 \%$ reduction in units sold. Sales of wind turbines less than 1 $\mathrm{kW}$ decreased the most: $63 \%$ on a capacity basis and $52 \%$ on a unit basis. Turbines sized 11 to $100 \mathrm{~kW}$ declined by $4 \%$ on a unit basis, but increased by $21 \%$ on a capacity basis. However, refurbished turbine installations claimed more than $66 \%$ of the small wind market segment, and more than $50 \%$ of all 2012 U.S. small wind capacity additions (Figure 10).

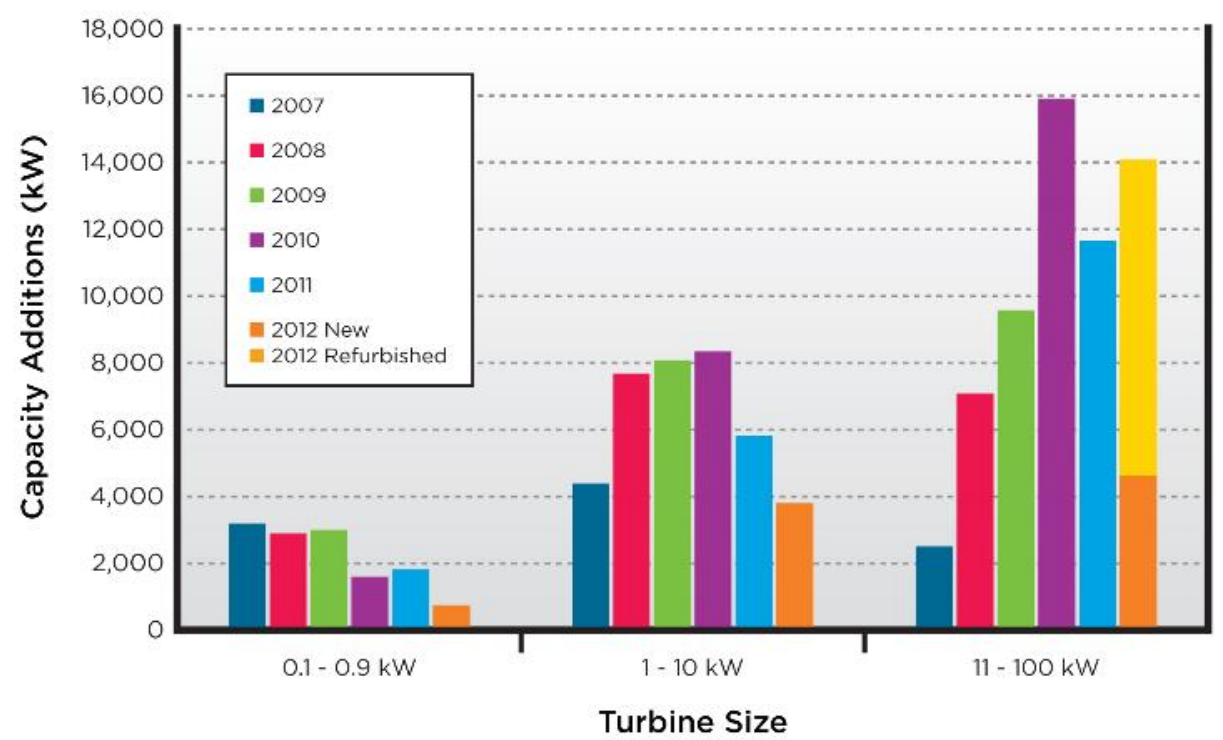

Figure 10. U.S. Small Wind Turbine Sales by Market Segment, 2007-2012 
Considering the $190 \mathrm{MW}$ of small wind turbines sold in the United States and exported by U.S. manufacturers over the past 10 years, refurbished units represented $5 \%$ on a capacity basis, and U.S. suppliers claimed nearly $88 \%$ of domestic and exported small wind capacity (Figure 11).

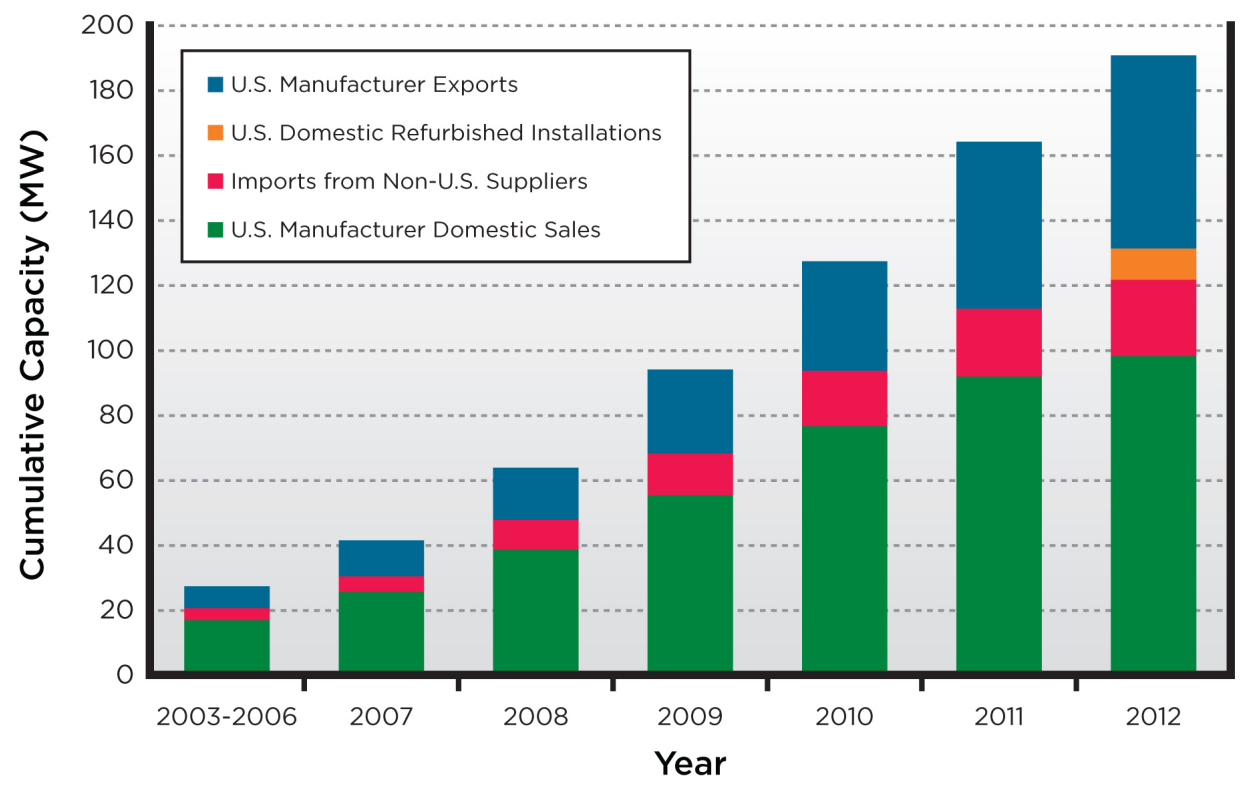

Figure 11. U.S. Small Wind Domestic, Imports, and Export Sales, 2003-2012

\subsection{Application Type}

While 2012 U.S. sales of off-grid wind turbines decreased by about $37 \%$ from 2011 , sales of grid-tied small turbines increased slightly, from 17.4 to $17.6 \mathrm{MW}$, but still down markedly from the rising trend of the previous four years (Figure 12). The decrease in domestic off-grid units, combined with the robust market for refurbished turbines rated $40 \mathrm{~kW}$ and above, led to a nearly $300 \%$ increase in the capacity-weighted average size for U.S. grid-tied small wind turbine units, from $5.8 \mathrm{~kW}$ in 2011 to $17 \mathrm{~kW}$ in 2012 (Figure 12). This helps to explain the minor overall decrease in small wind capacity additions from 2011 to 2012 compared to the large decrease in the number of units installed. The average U.S. small wind turbine (both off-grid and grid-tied) unit capacity nearly doubled, from $2.6 \mathrm{~kW}$ in 2011 to $5 \mathrm{~kW}$ in 2012 (Figure 12).

Off-grid wind turbines accounted for $72 \%$ of 2012 U.S. small wind sales in units, up from $59 \%$ in 2011. However, off-grid U.S. sales claimed just 5\% of 2012 small wind capacity, down from 9\% in 2011 and $41 \%$ in 2007. Off-grid sales declined from more than 4,300 units in 2011 to less than 2,700 units in 2012. The leading off-grid applications were telecommunications, commercial back-up power, residential, rural electricity and water, and military sites.

U.S. wind turbine manufacturers sold 13 different small, off-grid wind turbine models in 2012, compared to 10 in 2011. Non-U.S. manufacturers sold 10 off-grid turbine models in 2012, compared to 12 in 2011. Manufacturers based abroad offered four small wind turbine models that could be configured for either grid-tied or off-grid systems. 


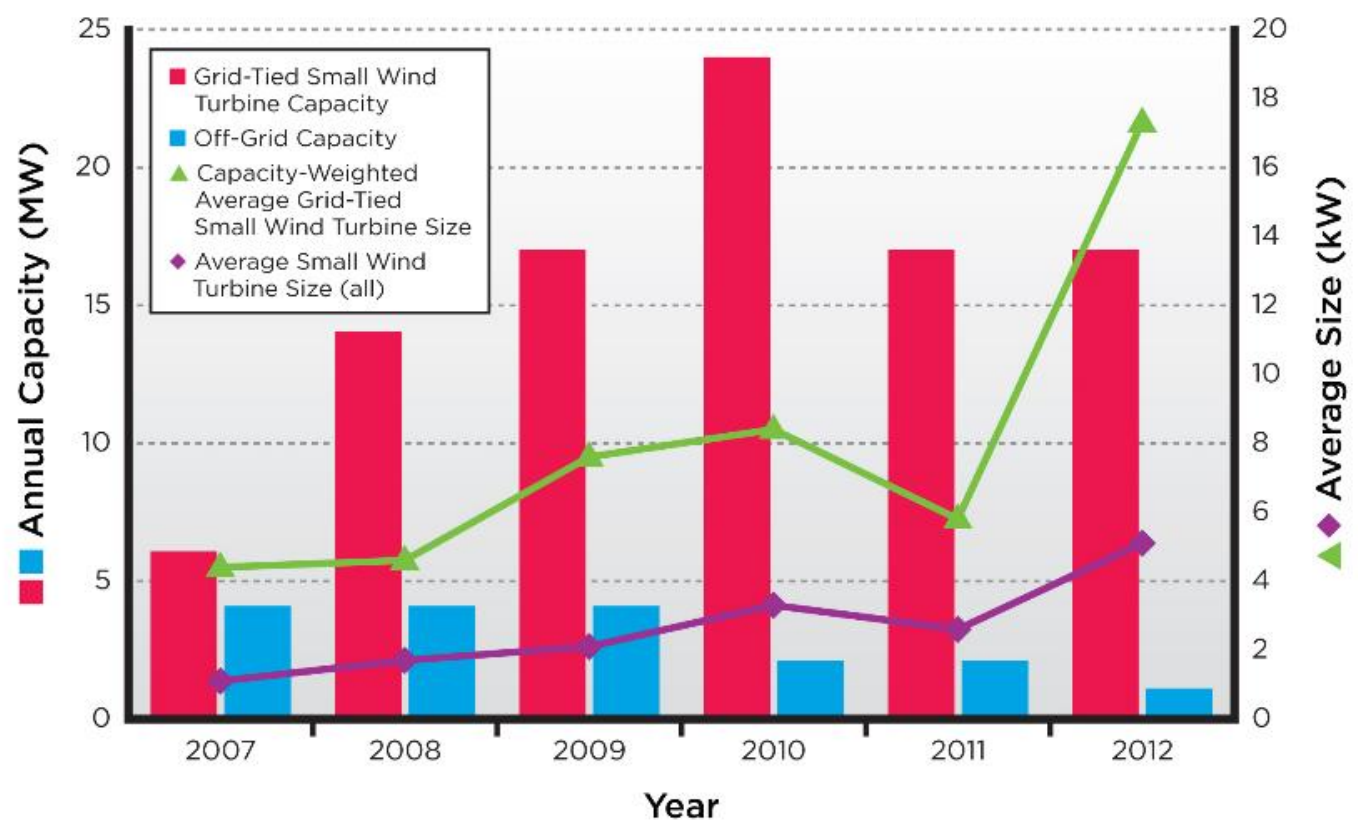

Figure 12. U.S. Small Wind Capacity and Unit Trends, 2007-2012

Small wind turbine manufacturers reported that behind the meter, ${ }^{7}$ onsite consumption made up the majority of their 2012 turbine installations on a capacity basis. Several reported that thirdparty sales of electricity from their turbines encompassed a large portion of their sales, including projects sold abroad and enrolled in European feed-in tariffs (FITs) ${ }^{8}$ Farms, small businesses, and schools were noted as important markets, and a few small wind manufacturers cited strong sales in remote net metered applications and hybrid systems.

\subsection{Types of Turbines and Towers}

Sales of 74 different small wind turbine models from 30 domestic and international suppliers were reported in the United States in 2012. A total of 14 U.S. manufacturers based in 11 states reported sales of 33 different small wind turbine models, and sales of 8 refurbished small wind turbine models were documented from 7 U.S.-based suppliers. An additional 11 small wind turbine manufacturers with a U.S. sales presence but headquartered abroad, including the UK, Spain, Canada, and South Africa, offered 33 different small wind turbine models in the United States in 2012. By comparison, 27 domestic and international manufacturers reported sales of 60 different small wind turbine models in the United States in 2011.

The majority of 2012 small wind turbine models sold in the United States were installed on selfsupporting lattice and guyed monopole towers (including tilt-up designs), reported by

\footnotetext{
7 "Behind the meter" means connected on the customer's side of the servicing utility's electric meter.

${ }^{8} \mathrm{~A}$ feed-in tariff is a long-term, fixed-price contract for renewable-generated electricity.
} 
manufacturers to be the best-selling tower designs for all but a few turbine models. Tower heights for small wind systems ranged from 9 to $49 \mathrm{~m}$, with most 2012 grid-tied small wind turbine installations featuring hub heights of more than $30 \mathrm{~m}$.

\subsection{Top 10 States}

Nevada, Iowa, Minnesota, Alaska, and New York led the states in installing the most small wind capacity in 2012. Comparing 2012 to 2011 year-end figures, the fastest growing state in 10-year cumulative small wind capacity, by a wide margin, was Nevada, followed by Virginia (Table 3).

Table 3. U.S. Small Wind Capacity Additions in 2012

\begin{tabular}{lllc}
\hline \multicolumn{2}{c}{ Top 10 States } & \multicolumn{2}{c}{ Fastest Growing States } \\
\hline \multicolumn{1}{c}{ State } & MW & \multicolumn{1}{c}{ State } & $\begin{array}{c}\text { 2003-2012 } \\
\text { Cumulative Growth } \\
\text { over 2003-2011 (\%) }\end{array}$ \\
\hline Nevada & 7.8 & Nevada & 183 \\
Iowa & 1.9 & Virginia & 56 \\
Minnesota & 1.8 & New York & 33 \\
Alaska & 1.3 & Minnesota & 30 \\
New York & 1.3 & Kansas & 28 \\
Kansas & 0.8 & Nebraska & 26 \\
Wisconsin & 0.5 & Alaska & 18 \\
Ohio & 0.4 & Iowa & 17 \\
Massachusetts & 0.4 & Vermont & 15 \\
California & 0.4 & Massachusetts & 10 \\
\hline
\end{tabular}

A total of 16 states currently have more than $2 \mathrm{MW}$ each of small wind turbines in distributed applications, as shown in Figure 13.

With nearly $8 \mathrm{MW}$ of small wind turbines installed in 2012, Nevada deployed the most small wind capacity for the year, considerably more than historical leaders Iowa, Minnesota, and California. Based on a review of records from NV Energy, the U.S. Department of Agriculture (USDA), and the U.S. Treasury, most of Nevada's recent small wind capacity has been from refurbished equipment made available by the accelerating repowering ${ }^{9}$ of several large California wind farms and aided by federal and state incentives as discussed below in Section 6.

\footnotetext{
${ }^{9}$ Repowering is the process of replacing wind turbines with newer units that either have greater capacity or more efficiency which results in a net increase of power generated.
} 


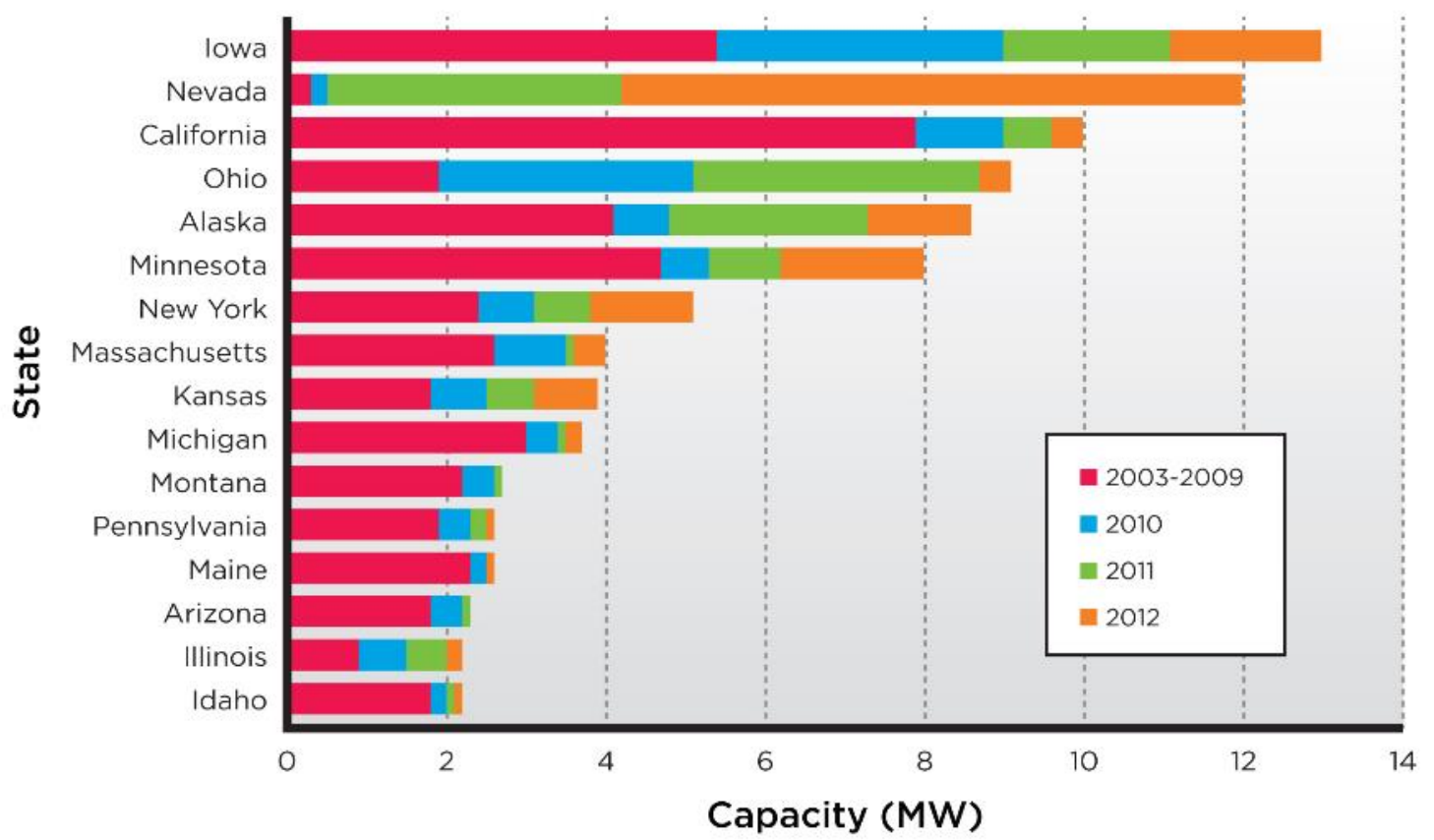

Figure 13. U.S. Small Wind Capacity Top States, 2003-2012

\subsection{Overview Maps}

Small wind turbine installations were documented in 38 states plus Puerto Rico and the U.S. Virgin Islands in 2012 (Figure 14), and in all 50 states over the past 10 years (Figure 15). This includes 8 southeastern states (Virginia, Kentucky, South Carolina, Georgia, Florida, Alabama, Mississippi, and Louisiana) that have no utility-scale wind projects installed.

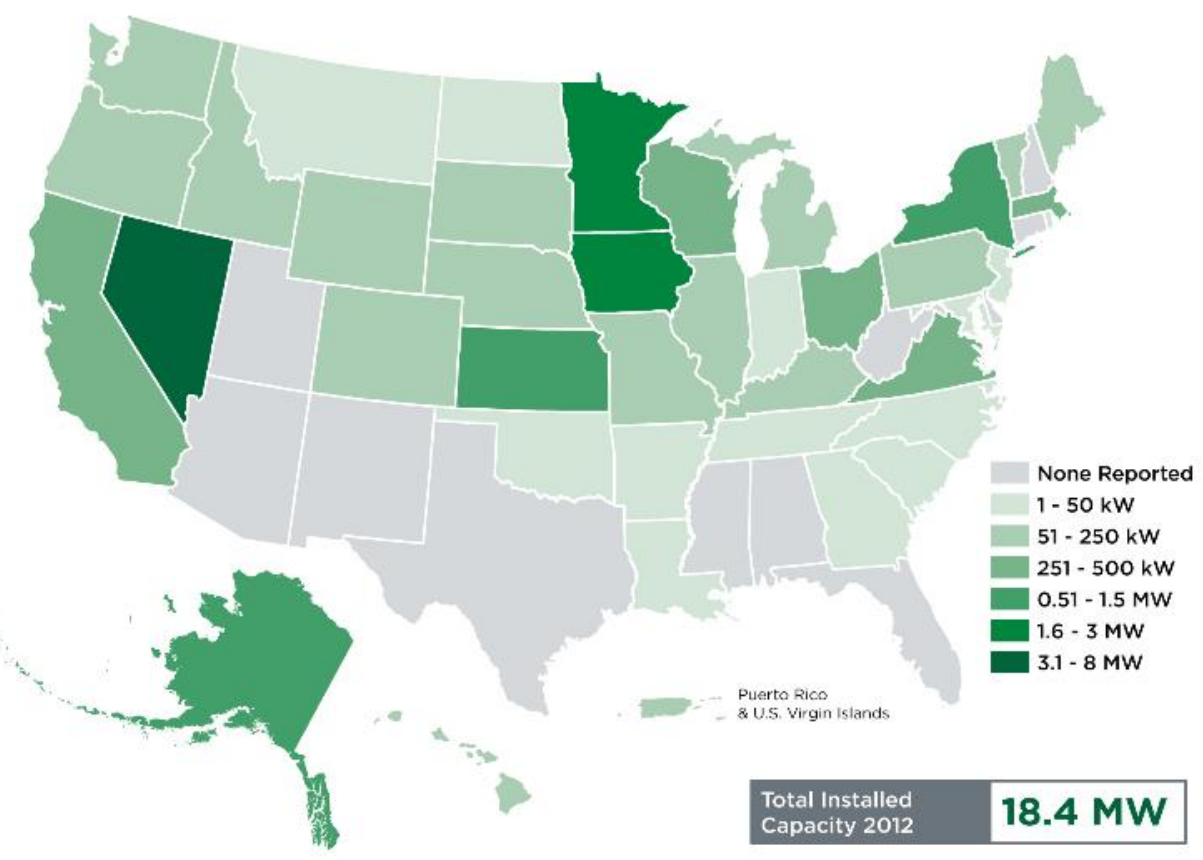

Figure 14. 2012 U.S. Small Wind Capacity Additions 


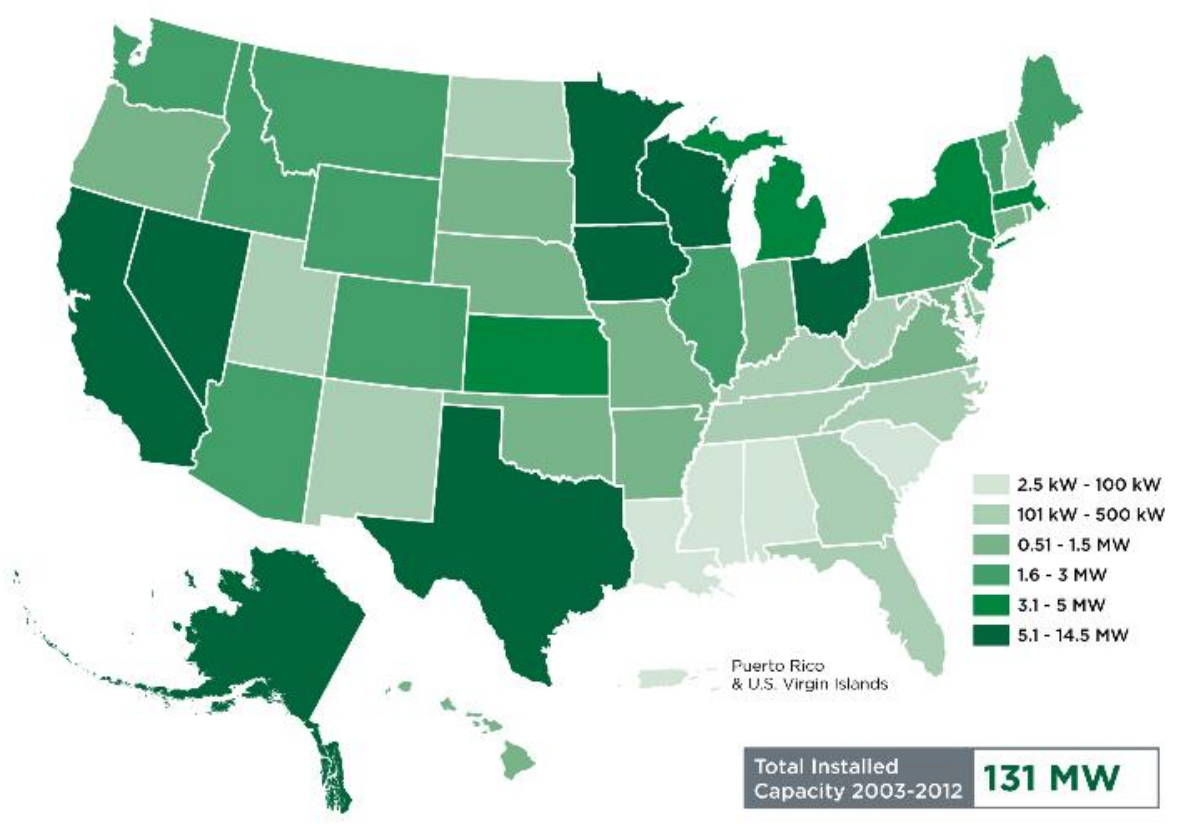

Figure 15. U.S. Small Wind Capacity, 2003-2012

\subsection{Domestic Sales}

Domestic sales capacity from U.S. small wind suppliers accounted for an $86 \%$ share of the 2012 U.S. small wind market capacity, up from $80 \%$ in 2011 (Figure 16). On a unit basis, U.S. suppliers claimed $91 \%$ of domestic small wind sales.

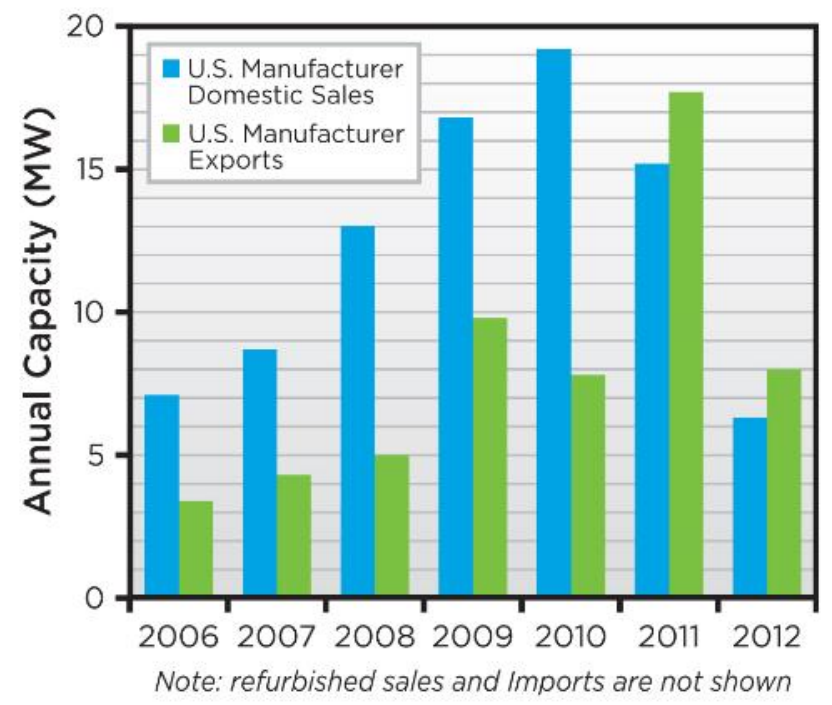

Figure 16. U.S. Small Wind Manufacturer Sales

Leading U.S.-based small wind turbine manufacturers continued favoring U.S. supply chain vendors for most of their turbine components, maintaining domestic content levels of 80 to $85 \%$. 


\subsection{Export Markets}

U.S. small wind turbine manufacturers exported $8 \mathrm{MW}$ to foreign markets in 2012 - primarily serving European feed-in tariffs (FITs), and to a lesser role, telecom, and wind-diesel applications - representing $56 \%$ of newly manufactured U.S. small wind sales capacity. In terms of units, 55\% of 2012 U.S. small wind turbines were exported, up from $41 \%$ in 2011.

After Europe (i.e., the UK, Italy, Germany, France, and Denmark), U.S. small wind manufacturers reported top international markets for export sales to be China, Chile, Canada, the Virgin Islands, Japan, Mexico, South America, Taiwan, India, Qatar, and Australia.

\section{Small Wind Export Case Study: NPS 100 in London}

A Northern Power Systems NPS 100-kW turbine located at the British Sky Broadcasting (BSkyB) headquarters in London, UK, represents a first agreement negotiated with Heathrow Airport approach control and the National Air Traffic Control Services to use radar "blanking" for wind turbines in close proximity to runways. The turbine is visible from afar, putting distributed wind in the urban spotlight.

Arup Associates designed the turbine's 60-m tower so that the twists of the tower reflect the rotational dynamics of the turbine. The design had to be modified to resist the turbine loads and was developed in close collaboration with Northern Power Systems. The spiraling and tapering tower effectively mitigates the risk of resonant excitation from wind vortices through innovative passive design, without expensive damping systems. The tower can be easily dismantled in three sections by reversing the erection sequence, enabling it to be fully recycled or re-used at the end of its life. The project was a challenging endeavor as Sky Studios intended to install and commission the turbine before the 2012 summer

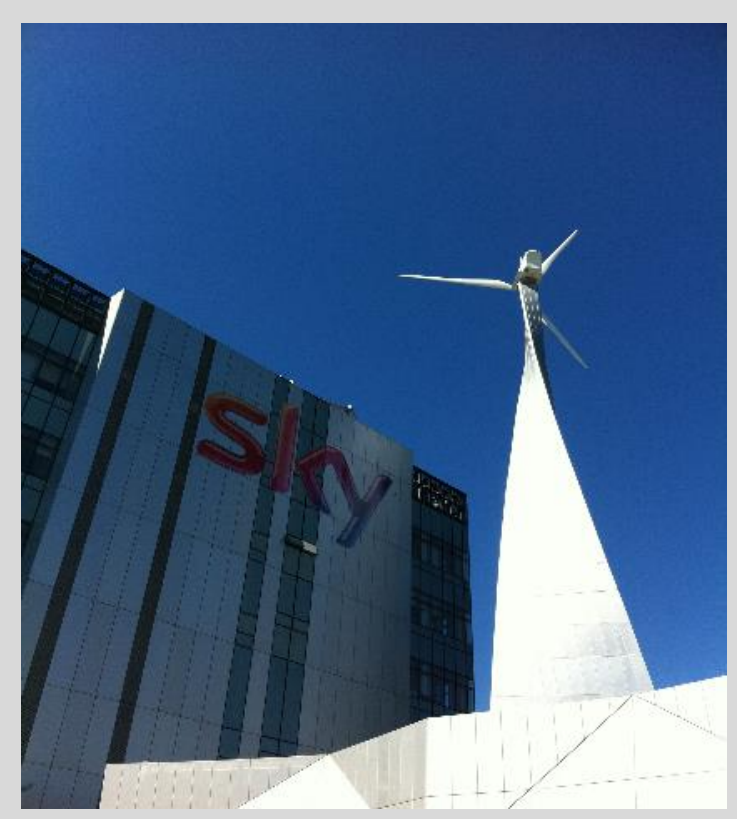

(Photo Credit: Northern Power Systems) Olympic Games.

The turbine provides an output of $133,000 \mathrm{kWh} /$ year, enough to power $60 \%$ of the building's lighting. The turbine is connected directly to the adjacent building's energy infrastructure through inverters and an isolation transformer, helping to minimize transmission losses. BSkyB benefits from the government FIT and reduced demand from the grid. All renewable energy generated is used onsite. The turbine's power output is currently exceeding expectations, delivering significant energy at relatively low wind-speeds.

"A wind turbine was the only renewable which made sense. It is not token or notional. The NPS 100 pays for itself well within the anticipated life of the turbine through reduced grid energy demand and local feed-in tariffs."

-Mike Beavan, the Arup Associates engineer responsible for the project.

Thanks to Bryan Mornaghi at Northern Power Systems for providing this case study. 
Exports exceeded domestic demand for the second year in a row for all four of the leading North American small wind manufacturers. However, strong international competition cut into U.S. small wind exports, which were down nearly 50\% from 2011. International suppliers (with a U.S. sales presence) remained level in their non-U.S. capacity sales.

The two strongest international markets for small turbines were the UK and Italy. Despite typically long planning processes required and organized, vocal opponents to wind energy development, the UK's strong wind resources and differentiated FIT structure resulted in all leading North American manufacturers faring well in the 2012 UK market. The 2012 UK market for small wind turbines was about $30 \mathrm{MW}$ (Gauntlett and Lawrence 2013), more than $60 \%$ greater than the 2012 U.S. small wind market. Alternately, Italy's flat FIT structure favors the larger of the small and mid-sized wind turbines.

While Japan has an attractive FIT, its certification procedures are slow and cumbersome, minimizing its market value for U.S. manufacturers in 2012. The Caribbean is emerging as a good market for small wind due to its favorable wind regime and high energy costs; however, institutional and government processes (e.g., permitting and government approval) remain significant barriers. While renewables for telecommunications remain strong due to the cost of diesel fuel, the falling cost of photovoltaics (PV) led to PV dominating 2012 telecom installations and retrofits. Ontario's FIT remains focused on PV and large wind, with a tariff level set too low to support favorable economics for small wind.

\subsection{Ownership Structures}

The majority of U.S. small wind turbines installed in 2012 are owned by homeowners, farmers and other individuals, followed by corporate, commercial, industrial, and non-taxed entities (e.g., local governments and schools). A few small wind turbine suppliers reported sales to community wind business structures with multiple local owners, and some small wind manufacturers noted sales in niche markets including streetlamps and oilfields.

\subsection{Installed Cost}

The installed cost reports for small wind turbines range widely, due to a considerable variety of suppliers (e.g., domestically manufactured, imports, and refurbished models), tower designs and heights, and methodologies for estimating expenses. Figure 17 presents the capacityweighted average installed costs for small turbines by type for 2011 and 2012 . Figure 18 presents the capacity-weighted average installed costs for small turbines by size range for 2012 .

\section{Partridge Farm}

Don Partridge of Batavia, New York, was so pleased with the performance of his two Bergey Excel turbines, he installed a third Bergey Excel in February 2012 on his private farm.

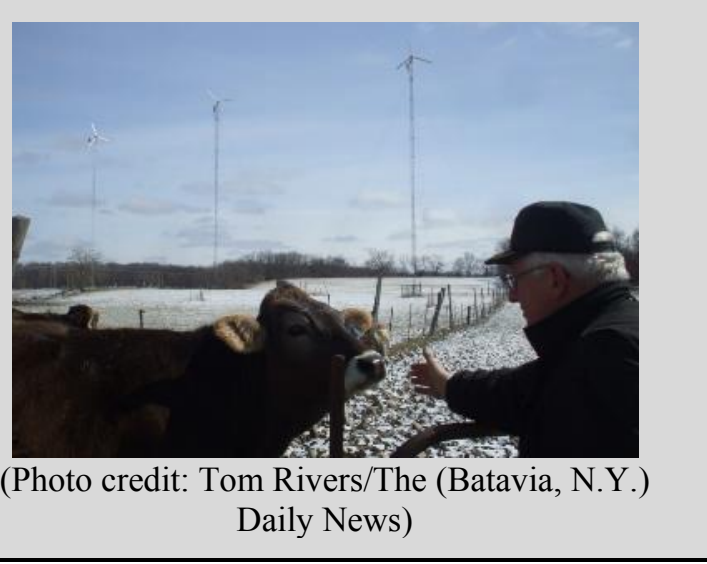




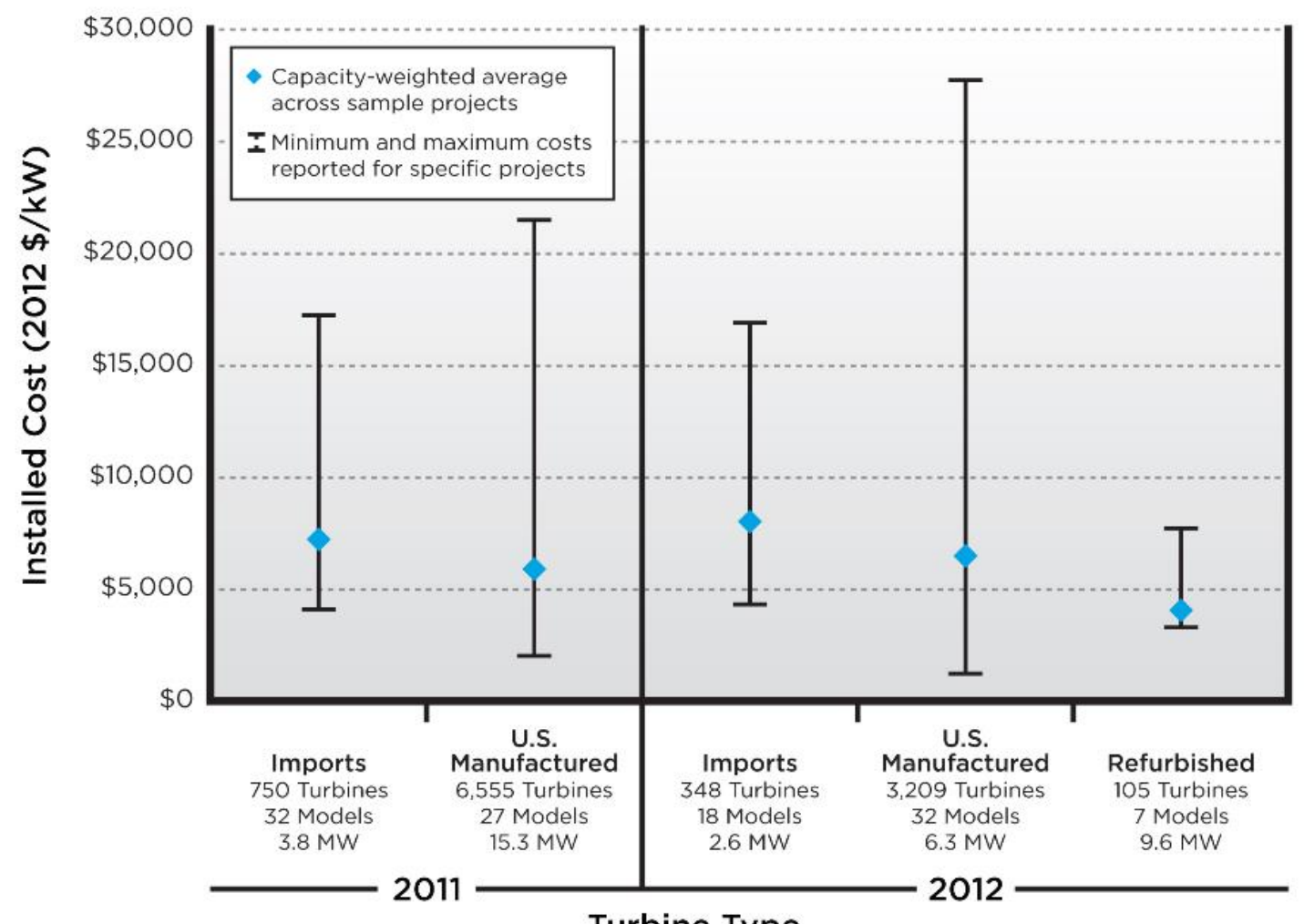

Turbine Type

Figure 17. U.S. Small Wind Turbines Average Installed Cost by Type, 2011-2012

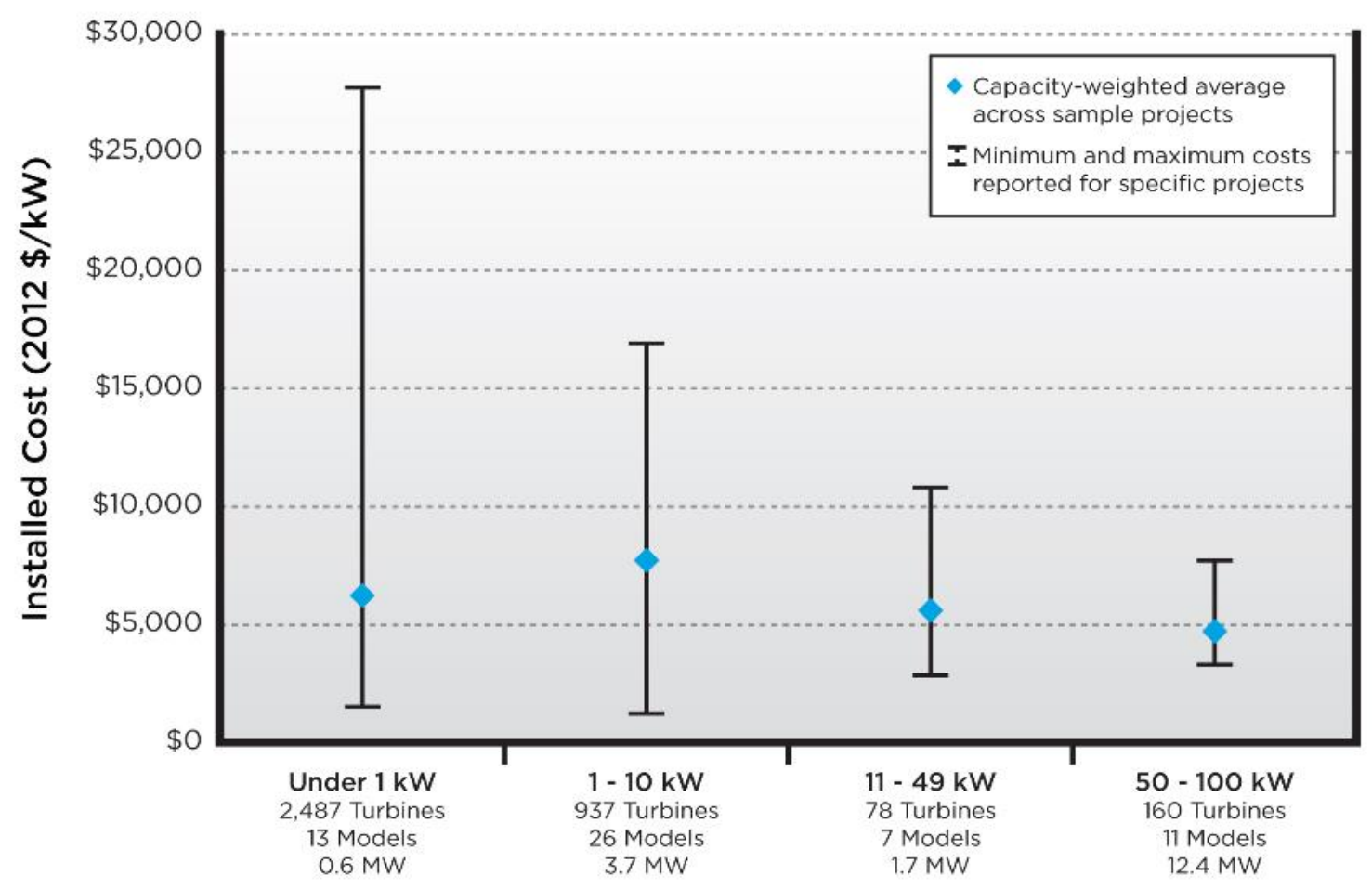

Turbine Size

Figure 18. 2012 U.S. Small Wind Turbines Average Installed Cost by Size 


\section{Small Wind Agricultural Case Study}

Lawrence Doody and Sons LLC is a 400 cow dairy farm in Tully, New York. The farm installed a $50 \mathrm{~kW}$ E-3120 Endurance Wind Power turbine on a 24-m lattice tower in September 2012 to protect the farm against escalating energy costs. The reported installed cost was $\$ 370,000$ and the installation was financed with an incentive payment from New York State Energy Research and Development Authority (NYSERDA), a Section 1603 payment, and cash from the farm owner. The turbine is expected to produce into the $100,000 \mathrm{kWh}$ range in 2013. Edward Doody says, "Our neighbors are happy to see it. Many honk their car horns as they drive by, and we regularly have passersby take pictures."

Thanks to Endurance for providing this case study.

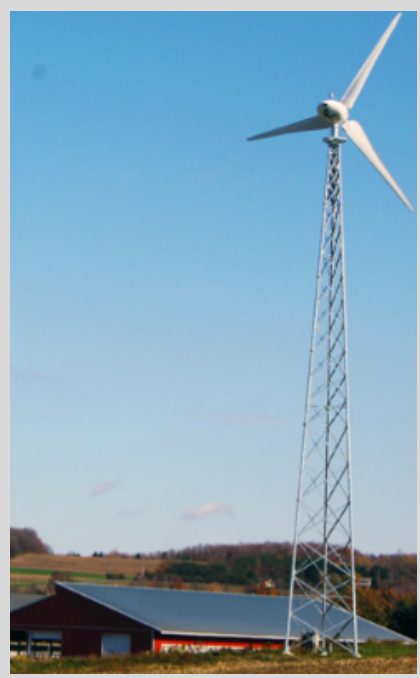

(Photo credit: Endurance)

\subsection{Success Drivers}

Industry leaders cited the desire to reduce utility bills as the primary motivation for domestic 2012 small wind turbine sales, along with related concerns over future utility rate increases caused by rising gas and coal prices, and the availability of state incentives. The value of onsite wind generation in providing a hedge against future fossil-fuel price uncertainty was recognized across applications: households, schools, farms, and municipal.

To a lesser degree, interest in being environmentally responsible and reducing pollution (including carbon) were cited as reasons some customers installed small wind turbines.

European Union goals and country energy policies were critical drivers for the European small wind market, and the resulting FITs accelerated demand for both small and mid-size turbines in distributed applications. 


\subsection{Mid-Size Wind Turbine Market (101 kW to $1 \mathrm{MW}$ )}

Distributed wind projects using mid-size wind turbines slightly exceeded small wind sales on a capacity basis in 2012 , representing nearly $11 \%$ of annual U.S. distributed wind capacity additions and less than $2 \%$ of all 2012 U.S. wind installations, including both distributed and non-distributed applications.

\subsection{Number and Types of Mid-Size Distributed Wind Projects}

Distributed wind projects using mid-size turbines saw strong growth in 2012 with 22 U.S. projects installed, serving distributed loads in 13 states. Mid-size distributed wind projects installed in 2012 totaled $19 \mathrm{MW}$, an over 50\% increase from mid-size distributed wind capacity installed in 2011.

Nearly all of the 2012 distributed wind installations using mid-size turbines were single-turbine projects, while only two projects were comprised of multiple turbines and the largest project consisted of six turbines.

A wide range of manufacturers served the mid-size distributed wind sector in 2012 , led by Gamesa (6 turbines, 5.1 MW), PowerWind (4 turbines, $3.6 \mathrm{MW}$ ), Aeronautica (3 turbines, 2.25 MW), and Nordic (2 turbines, 2.0 MW). A total of 11 manufacturers and 3 suppliers of refurbished equipment contributed to the mid-size distributed wind sector, with turbines ranging in size from 225 $\mathrm{kW}$ to $1.0 \mathrm{MW}$.

\section{Case Western Reserve University}

Case Western Reserve University installed two refurbished turbines in 2012, a 1 MW Nordex N54 (shown being installed on the left) and a 230 $\mathrm{kW}$ Vestas V27 (on the right).

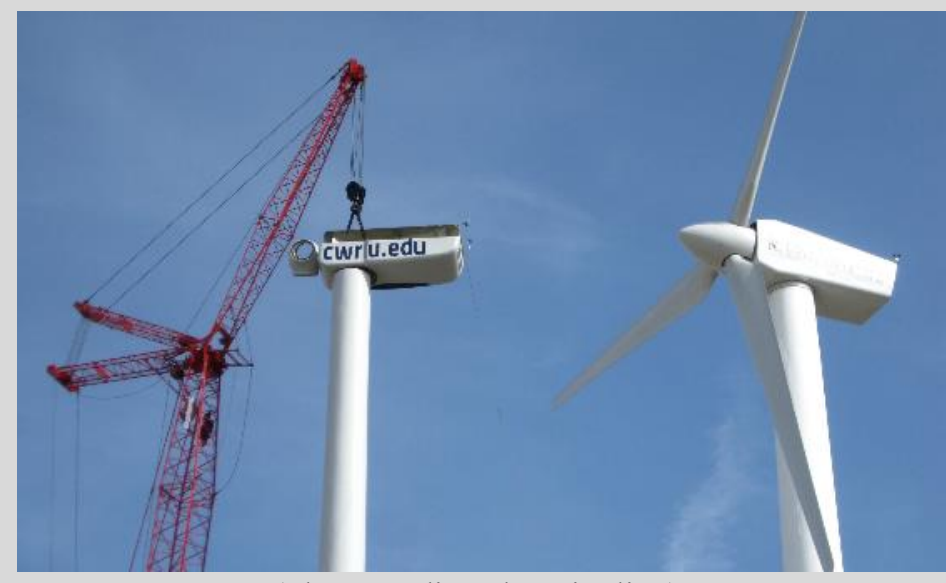

(Photo credit: John Yingling)

\subsection{Application Type}

Of the 22 distributed wind projects with mid-size wind turbines installed in 2012, 20 projects (totaling 13.9 MW) provided power directly for onsite use. The remaining two projects were connected to the distribution grid to serve local loads. 


\subsection{Types of Mid-Size Turbines and Towers}

A total of 11 manufacturers of mid-size wind turbines sold 11 different turbines for distributed projects installed in the United States in 2012. Of these manufacturers, 5 are based in Europe; 3 are based in the United States; and the remaining 3 are based in Japan, India, and Canada.

The majority of the mid-size wind turbines sold in the United States in 2012 had a rated capacity of more than $750 \mathrm{~kW}$ and were installed on tubular monopole towers, with one mid-size manufacturer supplying a tilt-up design. Tower heights of 2012 mid-size wind turbine installations ranged from 40 to $75 \mathrm{~m}$.

\subsection{Top 10 States for Mid-Size Distributed Wind}

Ohio, Washington, and Indiana led all states in installing the most mid-size wind turbines in distributed applications in 2012 (Table 4). Ohio and Washington combined account for nearly $50 \%$ of the installed capacity in the mid-size distributed wind market in 2012.

Table 4. U.S. Mid-Size Distributed Wind Capacity Additions in 2012

\begin{tabular}{lllc}
\hline \multicolumn{2}{c}{ Top 10 States } & \multicolumn{2}{c}{ Fastest Growing States } \\
\hline \multicolumn{1}{c}{ State } & MW & \multicolumn{1}{c}{ State } & $\begin{array}{c}\text { 2003-2012 Cumulative } \\
\text { Growth over 2003-2011 (\%) }\end{array}$ \\
\hline Ohio & 4.9 & Kansas & (a) \\
Washington & 4.3 & New York & 1771 \\
Indiana & 2.7 & Washington & 159 \\
Kansas & 1.0 & Ohio & 152 \\
North Dakota & 1.0 & North Dakota & 93 \\
California & 1.0 & Indiana & 20 \\
Iowa & 0.9 & California & 13 \\
Texas & 0.9 & Iowa & 11 \\
New York & 0.9 & Massachusetts & 8 \\
Massachusetts & 0.6 & Texas &
\end{tabular}

(a) First mid-size distributed wind projects installed

Kansas and New York both saw their first mid-size distributed wind project installations in 2012. Each had one single-turbine project installed, a 1.0 MW Nordic (Kansas) and a $0.85 \mathrm{MW}$ Gamesa (New York). Washington's single 2012 mid-size project of 4.3 MW increased the cumulative capacity in the sector by over 17 times - the only prior mid-size installations in the state were two $120 \mathrm{~kW}$ projects in 2011. Comparing 2012 to 2011 year-end figures, the other fastest growing states in 10-year cumulative mid-size distributed wind capacity were Ohio and North Dakota.

On a cumulative basis, Minnesota led all states with respect to mid-size distributed wind installations, although it did not have any mid-size installations in 2012, distantly followed by Texas (Figure 19). Ohio's 4.9 MW addition in 2012 pushed Ohio into the top three with respect to the 10-year cumulative total, while previous leaders Iowa and Massachusetts fell behind in 2012. 


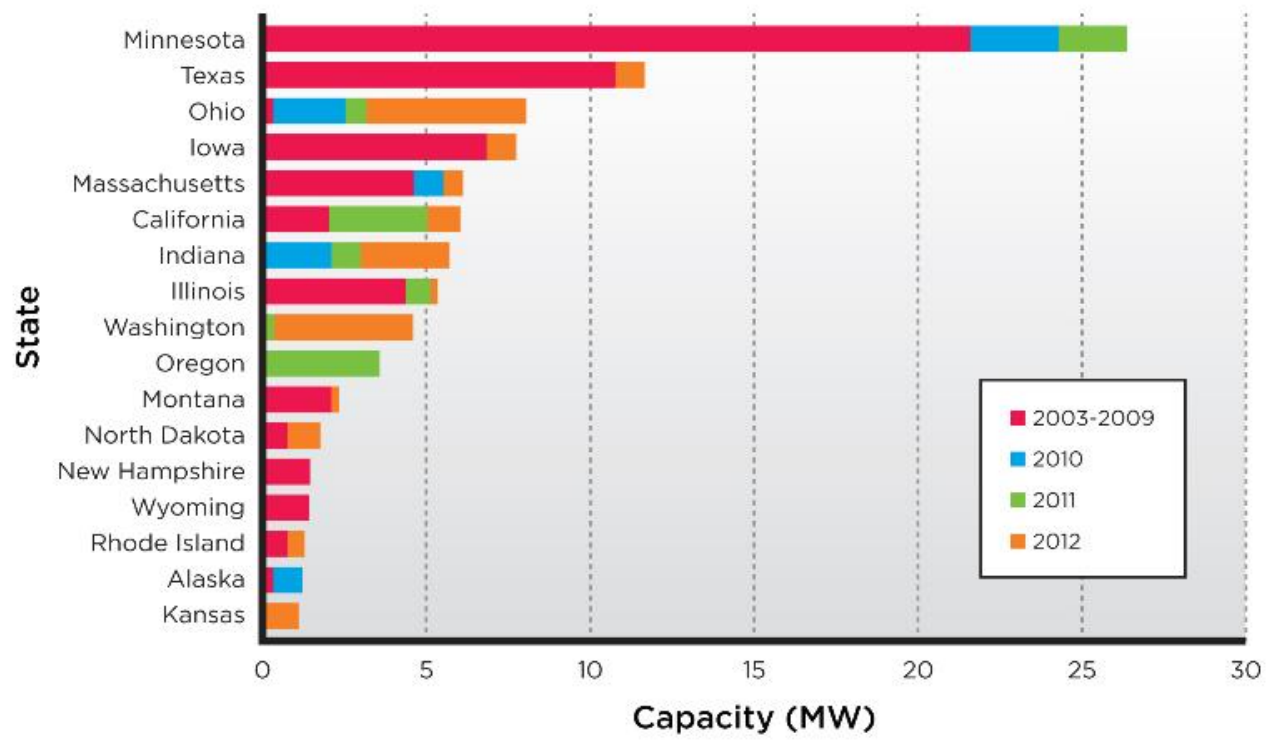

Figure 19. U.S. Mid-Size Distributed Wind Capacity Top States, 2003-2012

\subsection{Overview Maps}

Mid-size distributed wind installations were documented in 13 states in 2012 (Figure 20), and have been documented in 24 states over the past 10 years (Figure 21).

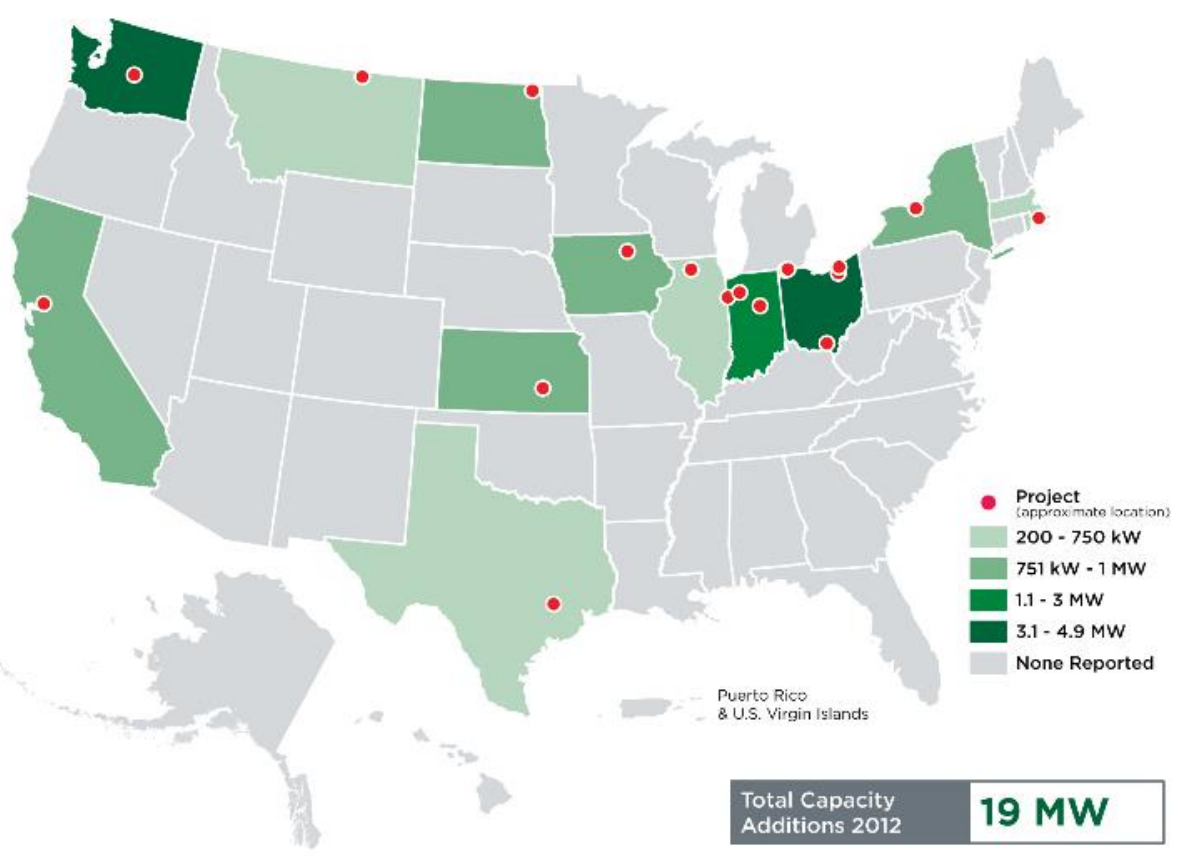

Figure 20. 2012 U.S. Mid-Size Wind Capacity Additions 


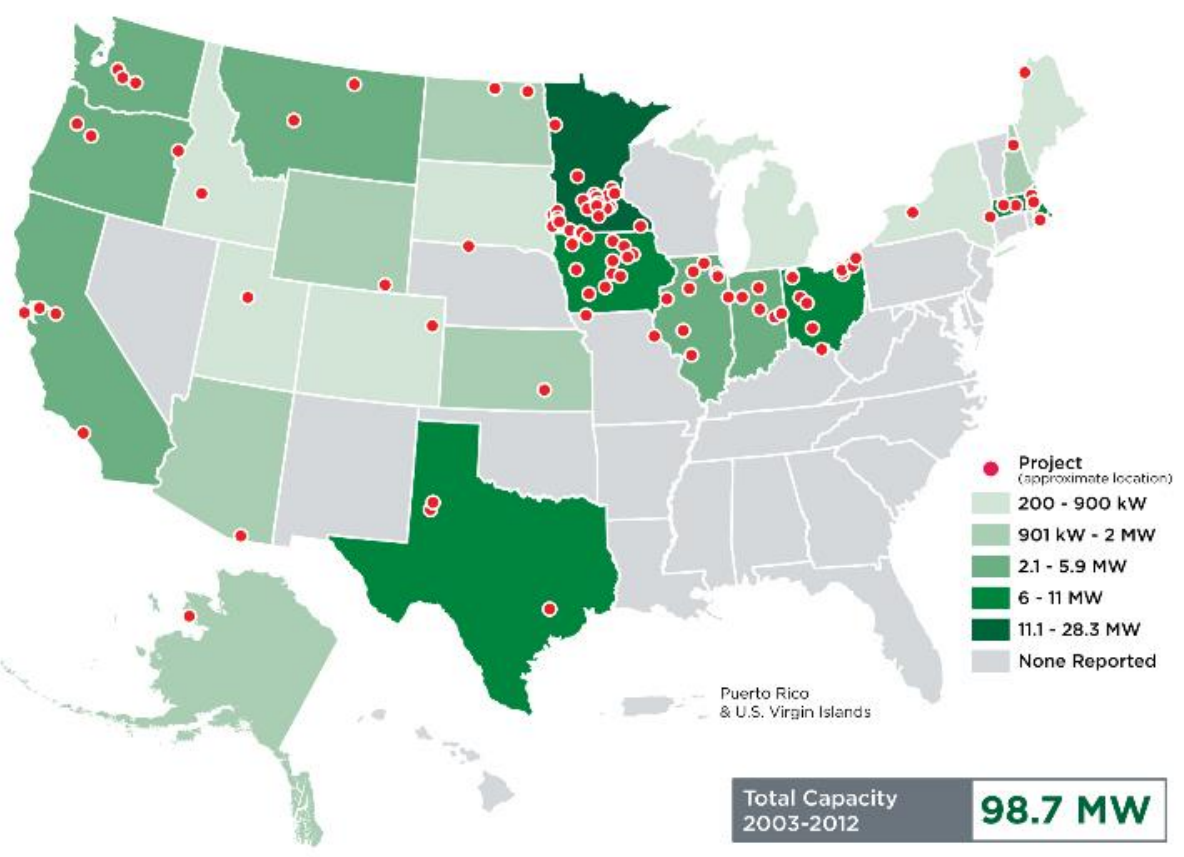

Figure 21. U.S. Mid-Size Wind Capacity, 2003-2012

\subsection{Ownership Structures}

Distributed wind projects installed in 2012 using mid-size turbines employed a variety of ownership models. A total of 11 mid-size 2012 distributed wind projects are owned by schools (from elementary schools to community colleges and universities); 6 are owned by government or non-profit agencies (e.g., a municipality); 4 are owned by commercial or industrial facilities where the energy is used onsite to power the facility; and one is owned by an independent power producer (IPP) which supplies the energy to the local distribution grid.

\subsection{Installed Cost}

Installed cost data were available for 8 of the 22 distributed wind projects with mid-size wind turbines installed in 2012. The mid-size turbine type represents a large range of sizes, from 101 $\mathrm{kW}$ to $1 \mathrm{MW}$. Capacity-weighted average cost data for 2011 and 2012, based on project size, are presented in Figure 22.

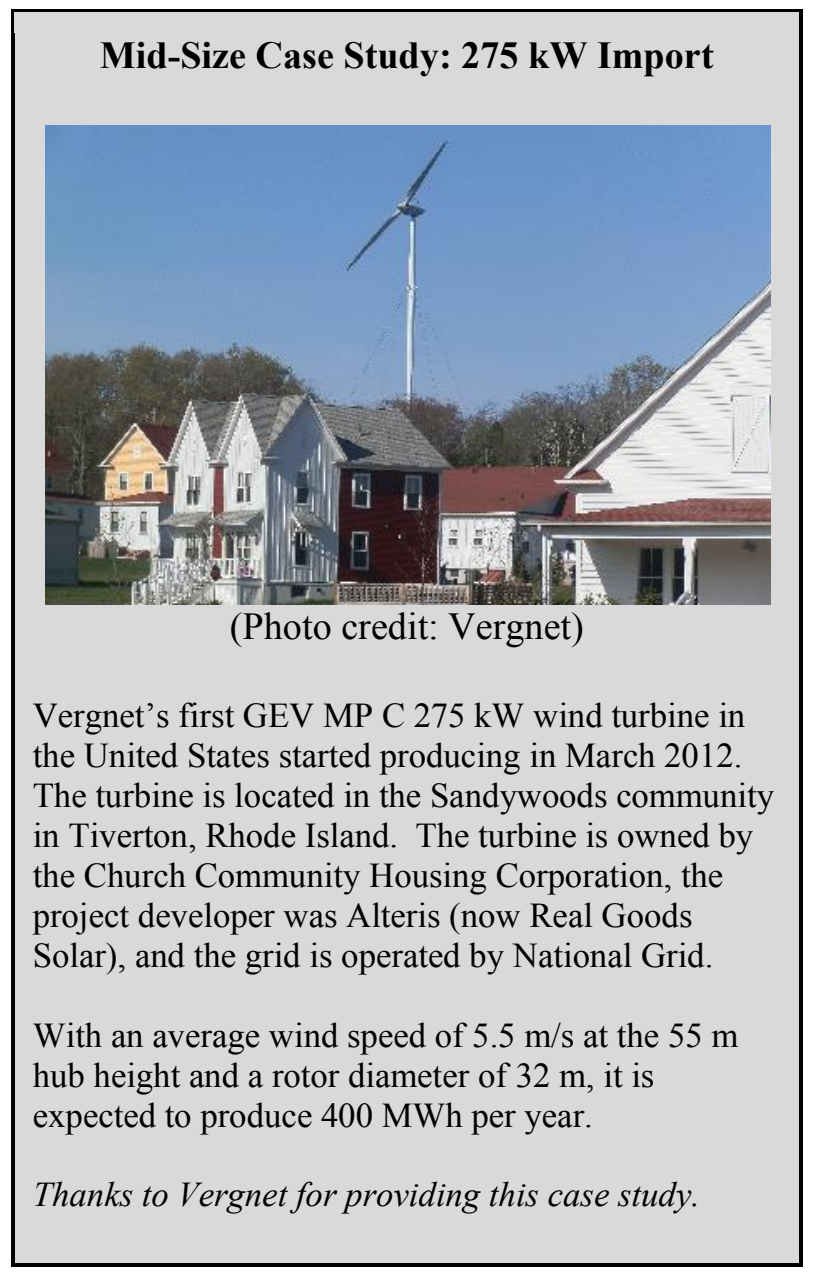




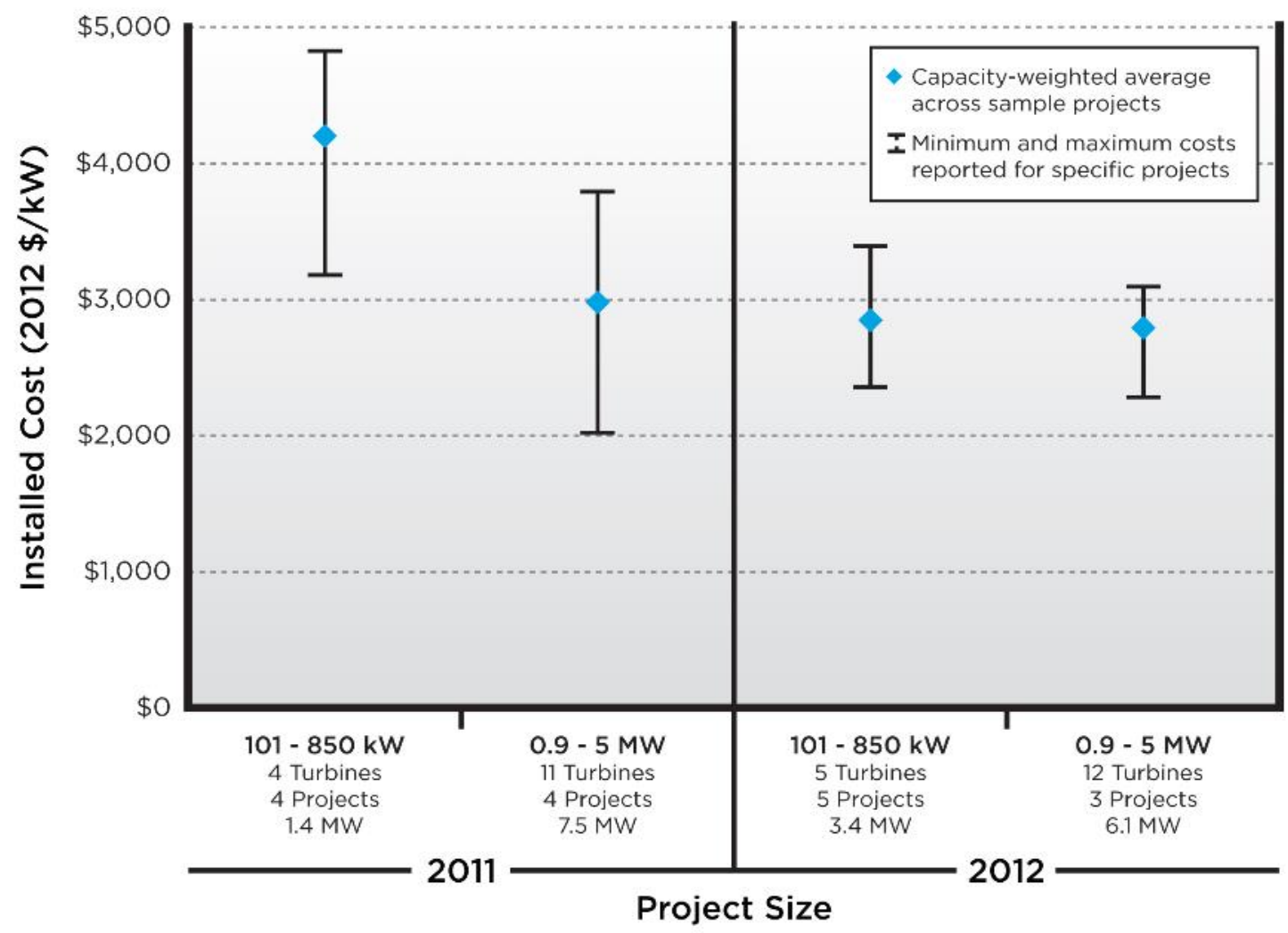

Figure 22. Average Installed Cost of Mid-Size Turbines in Distributed Applications, 2011-2012

In 2011 , the cost data in the 101 - to $850-\mathrm{kW}$ range represent projects using 750,500 (refurbished), and $400 \mathrm{~kW}$ turbines. The projects in this same size range in 2012 used a wider variety of turbine sizes: 150, 250, 750, and $850 \mathrm{~kW}$. Project size ranges presented in Figure 22 were selected based on the available cost data.

\subsection{Success Drivers}

Drivers that led to successful 2012 mid-size distributed wind developments included a final push to take advantage of the expiring Section 1603 program; persistence of a robust market in Ohio, carrying over from the state's Advanced Energy Fund from previous years; local champions and receptive permitting environments; and local visibility at schools. Finally, focused market development in the agricultural sector, which remains eligible for the $30 \%$ federal Investment Tax Credit (ITC) through 2013, ${ }^{10}$ is leading to an increase in farm installations of mid-size wind turbines.

\footnotetext{
${ }^{10}$ The ITC and Section 1603 program are discussed in more detail in Section 6.2.2.
} 


\subsection{Utility-Scale Wind Turbine Market (Larger than $1 \mathrm{MW}$ )}

Utility-scale systems account for the majority of installed distributed wind capacity in the United States, and comprised nearly $79 \%$ of 2012 distributed wind capacity additions. These applications include installations at school, industrial, agricultural, and commercial sites providing onsite utility bill reduction; farmer- and community-owned and LLC projects selling electricity to the local grid; and electric cooperative- and municipal utility-owned projects that are integrated into their generation portfolios. These projects continue to be popular due to their enhanced local economic and environmental benefits, as well as the economic, operational, and security benefits associated with diversifying utility generation portfolios.

\subsection{Number and Types of Projects}

Improved technology and increased competition in utility-scale wind systems have resulted in expanding applications for multi-megawatt systems connected to the distribution grid. In 2012, 47 distributed projects using utility-scale turbines were installed serving distributed loads in 10 states.

31 of the projects were single utility-scale turbine applications, 10 were two-turbine projects, and 7 projects ranged from three to six turbines.

The 47 projects consisted of 78 utility-scale turbines resulting in $138 \mathrm{MW}$ of installed capacity (roughly double 2011 installed capacity). While 13 turbine manufacturers supplied the projects, the top 5 accounted for $75 \%$ of turbines and megawatts. GE led the turbine sales (27 turbines, 42.7 MW), followed by Goldwind (13 turbines, 23.5 MW), Vestas (10 turbines, 19.2 MW), Gamesa (6 turbines, $12 \mathrm{MW}$ ), and Clipper (4 turbines, $10 \mathrm{MW}$ ).

\subsection{Application Type}

Utility-scale applications ranged from onsite generation (e.g., farms, commercial, industrial, schools, wastewater treatment) to utility supply (e.g., investor-owned, municipal, and cooperatives) and both private- and community-owned generation sited near large loads. Approximately two-thirds of the 2012 U.S. utility-scale distributed wind projects, totaling $88 \mathrm{MW}$, provide power directly for onsite use. The remaining projects, totaling $50 \mathrm{MW}$, are connected to a distribution grid to serve local loads.

\subsection{Types of Turbines and Towers}

Manufacturers of utility-scale wind turbines used in distributed applications were from a wide array of locations around the world, including Europe, China, South Korea, and the United States. The majority of distributed projects using utility-scale wind turbines used turbines between 1 and $2 \mathrm{MW}$ in size installed on $80 \mathrm{~m}$ tubular towers.

\subsection{Top 10 States}

Iowa led all states with 15 projects using utility-scale turbines in distributed applications (Table 5). Massachusetts led the northeast United States with 10 projects. California led the western United States with 11 projects, with 10 of those projects installed behind the meter at large load facilities, primarily large retail and industrial customers. 
Table 5. U.S. Utility-Scale Distributed Wind Capacity Additions in 2012

\begin{tabular}{lclc}
\hline \multicolumn{2}{c}{ Top 10 States } & \multicolumn{2}{c}{ Fastest Growing States } \\
\hline \multicolumn{1}{c}{ State } & MW & \multicolumn{1}{c}{ State } & $\begin{array}{c}\text { 2003-2012 } \\
\text { Cumulative Growth } \\
\text { 2003-2011 }(\%)\end{array}$ \\
\hline Iowa & 33.8 & Wisconsin & (a) \\
Massachusetts & 26.2 & Vermont & (a) \\
California & 21.4 & Rhode Island & 400 \\
Wisconsin & 17.9 & Massachusetts & 103 \\
Texas & 11.0 & California & 75 \\
Vermont & 10.0 & Ohio & 62 \\
Rhode Island & 6.0 & Iowa & 53 \\
Ohio & 6.0 & Illinois & 42 \\
Illinois & 4.2 & New Jersey & 20 \\
New Jersey & 1.5 & Texas & 7 \\
\hline
\end{tabular}

(a) First mid-size distributed wind projects installed

The top four states (i.e., Iowa, Massachusetts, California, and Wisconsin) accounted for $72 \%$ of the utility-scale distributed wind applications installed in 2012 and $77 \%$ of installed projects. Wisconsin and Vermont both had their first utility-scale distributed wind projects installations in 2012. Comparing 2012 to 2011 year-end figures, the other fastest growing states in 10-year cumulative utility-scale distributed wind capacity were Rhode Island, Massachusetts, and California.

On a cumulative basis, Texas leads all states with respect to distributed applications using utilityscale turbines, followed by Iowa and Minnesota (Figure 23).

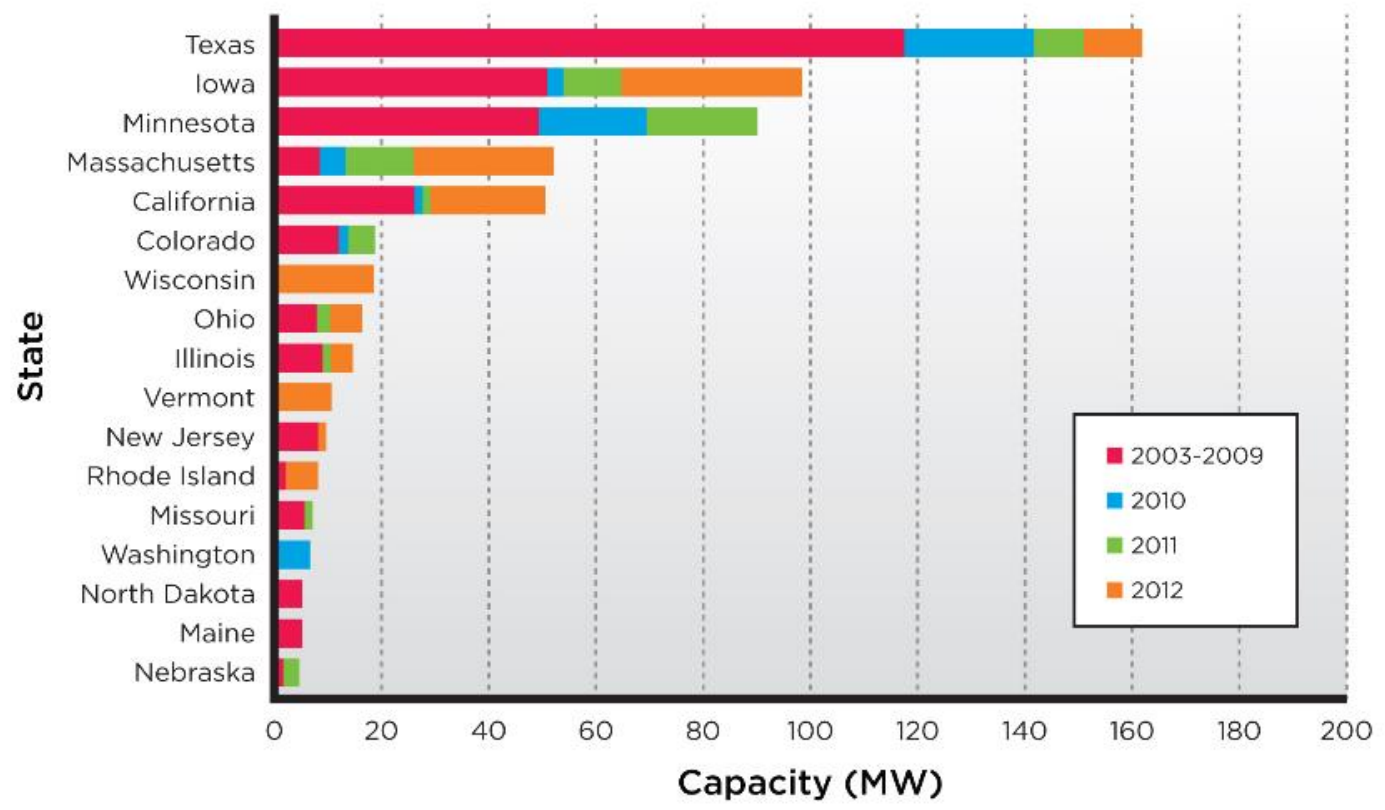

Figure 23. U.S. Utility-Scale Distributed Wind Capacity, Top States, 2003-2012 


\subsection{Overview Maps}

Distributed wind projects using utility-scale wind turbines were documented in 10 states in 2012 (Figure 24), and in 23 states over the past 10 years (Figure 25).

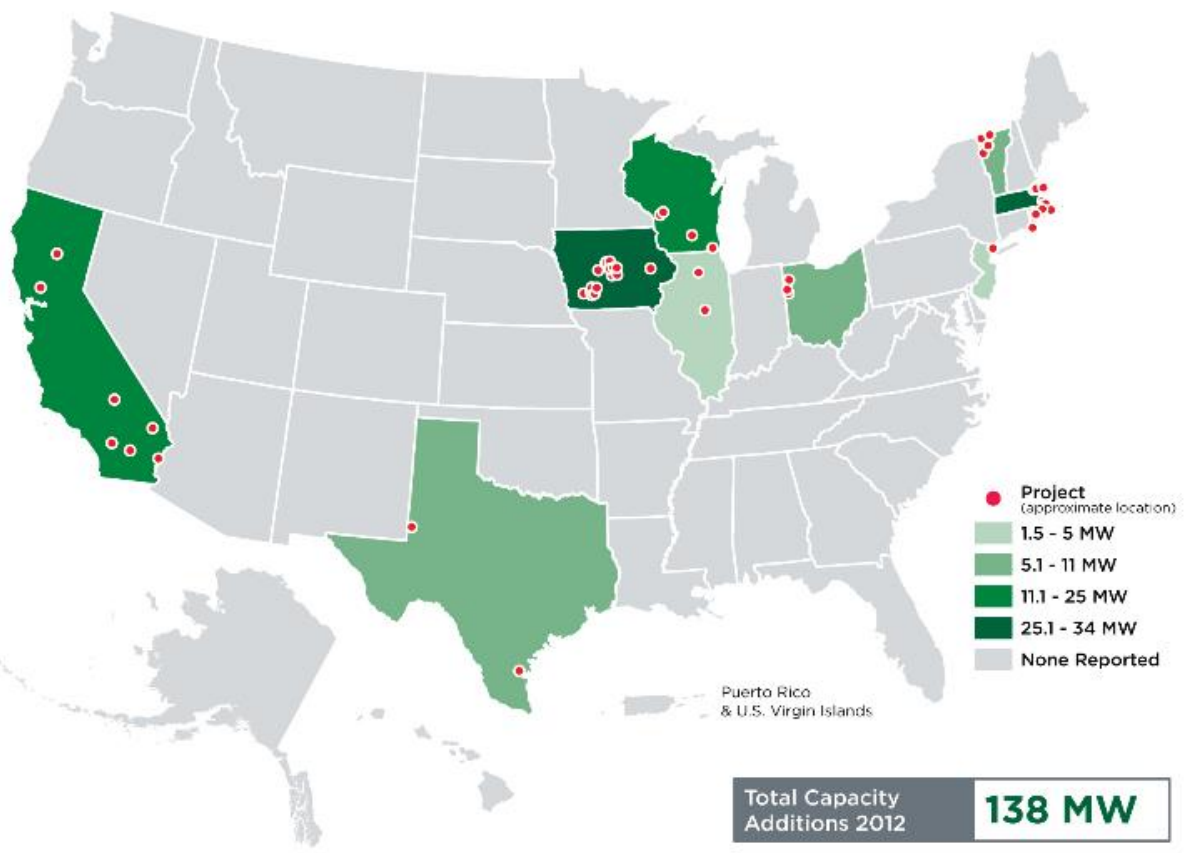

Figure 24. 2012 U.S. Utility-Scale Distributed Wind Capacity Additions

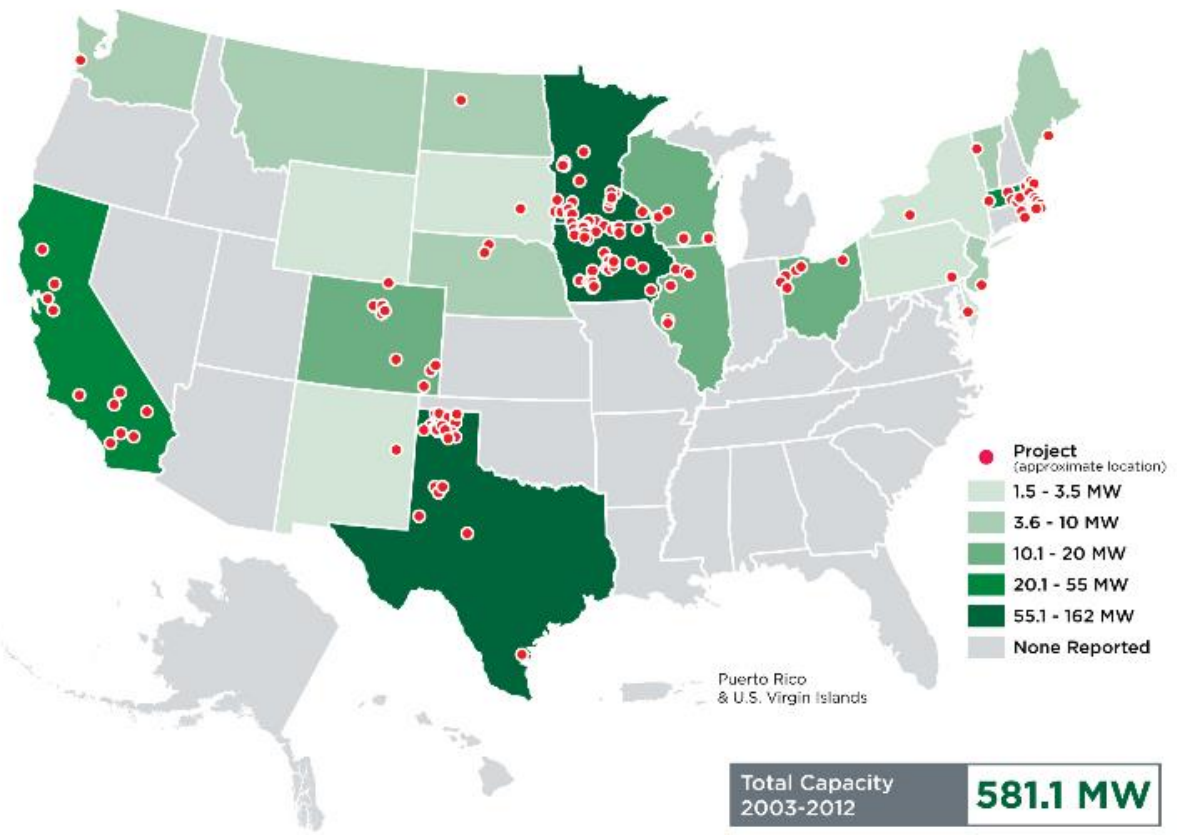

Figure 25. U.S. Utility-Scale Distributed Wind Capacity, 2003-2012 


\subsection{Ownership Structures}

The majority of 2012 U.S. distributed wind projects using utility-scale turbines ( 42 of the 47 projects) were installed for commercial or industrial purposes, owned by the facility to serve the onsite load; or, by IPPs who provide the energy to the distribution grid or a specific facility through a power purchase agreement (PPA). The remaining five projects were installed by government or non-profit agencies or schools.

\subsection{Installed Cost}

Installed cost data were available for 26 of the 472012 U.S. utility-scale distributed wind projects, representing 78 of the $138 \mathrm{MW}$ installed. As shown in Figure 26, the capacityweighted average for distributed wind projects using utility-scale turbines hovered around $\$ 2,500 / \mathrm{kW}$, with the overall average only slightly higher at $\$ 2,540 / \mathrm{kW}$. These projects are all 10 MW in size or smaller. This average cost is in line with research from DOE's Lawrence Berkeley National Laboratory, which finds a steady drop in per-kW average installed costs when moving from projects of $5 \mathrm{MW}$ or less (approximately $\$ 2,500 / \mathrm{kW}$ ) to projects in the $20-50$ MW range (approximately $\$ 2,100 / \mathrm{kW}$ ) (Wiser and Bolinger 2012).

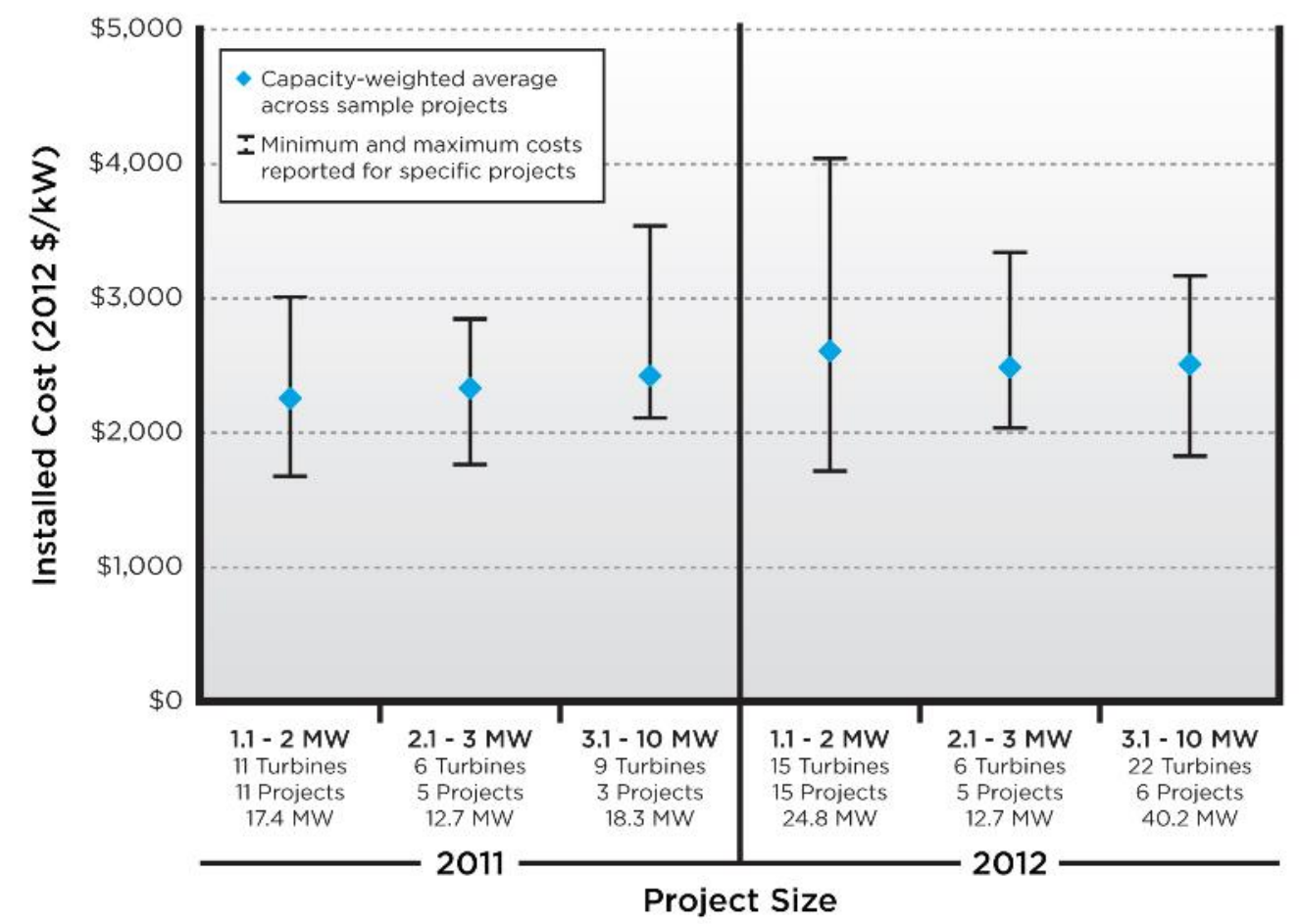

Figure 26. Utility-Scale Turbines in Distributed Applications Average Installed Cost, 2011-2012

The wide range of costs reported for single-turbine deployments (i.e., the 1.1 - $2 \mathrm{MW}$ project size range in Figure 26) is due to variations in wind turbine prices; shipping costs; and development, permitting, interconnection, and other balance-of-plant expenses. 


\subsection{Success Drivers}

The main drivers for 2012 U.S. utility-scale distributed wind projects depended on the specific project owner, host, and application and included the following:

- energy cost savings and future rate hedging in net metered applications and a desire to be more environmentally responsible

- income diversification for farmer- and landowner-owned projects

- generation portfolio diversification and rate stability for utility-owned projects.

Other drivers for utility-scale wind turbine projects included the impending expiration of important federal policies at the end of 2012.

Midwest utility-scale distributed wind markets that fared well in 2012 were driven by farmer prosperity with high commodity prices, and wholesale PPAs dominated 2012 utility-scale distributed wind applications. Midwest markets had relatively good financing available from local banks and equity partners; however, monetizing tax credits remained a challenge.

Distributed wind projects in Iowa were aided by the state's $\$ 0.015 / \mathrm{kWh}$ tradable tax credit, Section 1603 payments, and the USDA Rural Energy for America Program (REAP).

In California, drivers for the utility-scale distributed wind installations included moderately high and uncertain energy prices and the state's carbon regulations for large energy users. The scheduled cessation of the federal Business Energy ITC (extended in January 2013) drove the state's major distributed wind developer to focus efforts on expediting construction, while postponing development efforts to 2013. An additional economic incentive was the California in-state rebate program, which all these projects received.

\section{Utility-Scale Case Study: Foundation Power at Anheuser-Busch}

Anheuser-Busch entered into a partnership with San Francisco-based Foundation Windpower in 2011 to buy the output of one GE 1.5-MW wind turbine at its Fairfield, California Budweiser brewery to significantly reduce the brewery's dependence on commercially produced electricity. Although sited at Anheuser-Busch's brewery, the turbine is owned and operated by Foundation Windpower. This business arrangement allows the brewery to purchase renewable energy through a PPA with Foundation Windpower. The project was commissioned in November 2011 and produced $3,260 \mathrm{MWh}$ in 2012 , about $25 \%$ of the brewery's total load. The brewery plans to add a second turbine. The $\$ 5.9$ million project was financed with third-party equity, loans, and funding from California's Self-Generation Incentive Program. The project generated nearly 40 temporary construction jobs and 3 ongoing maintenance jobs.

Thanks to Windustry for providing this case study. 


\subsection{Federal and State Incentives and Policies}

Federal, state, and utility incentives and policies - rebates, tax credits, grants, net metering, production-based incentives, loan funds, and other incentives - continue to play an important role in the development of wind and other renewable energy projects.

Figure 27 provides an overview of the federal and state funding provided for distributed wind projects in 2012 and shows the total number of awards given in the top states (by 2012 funding levels).

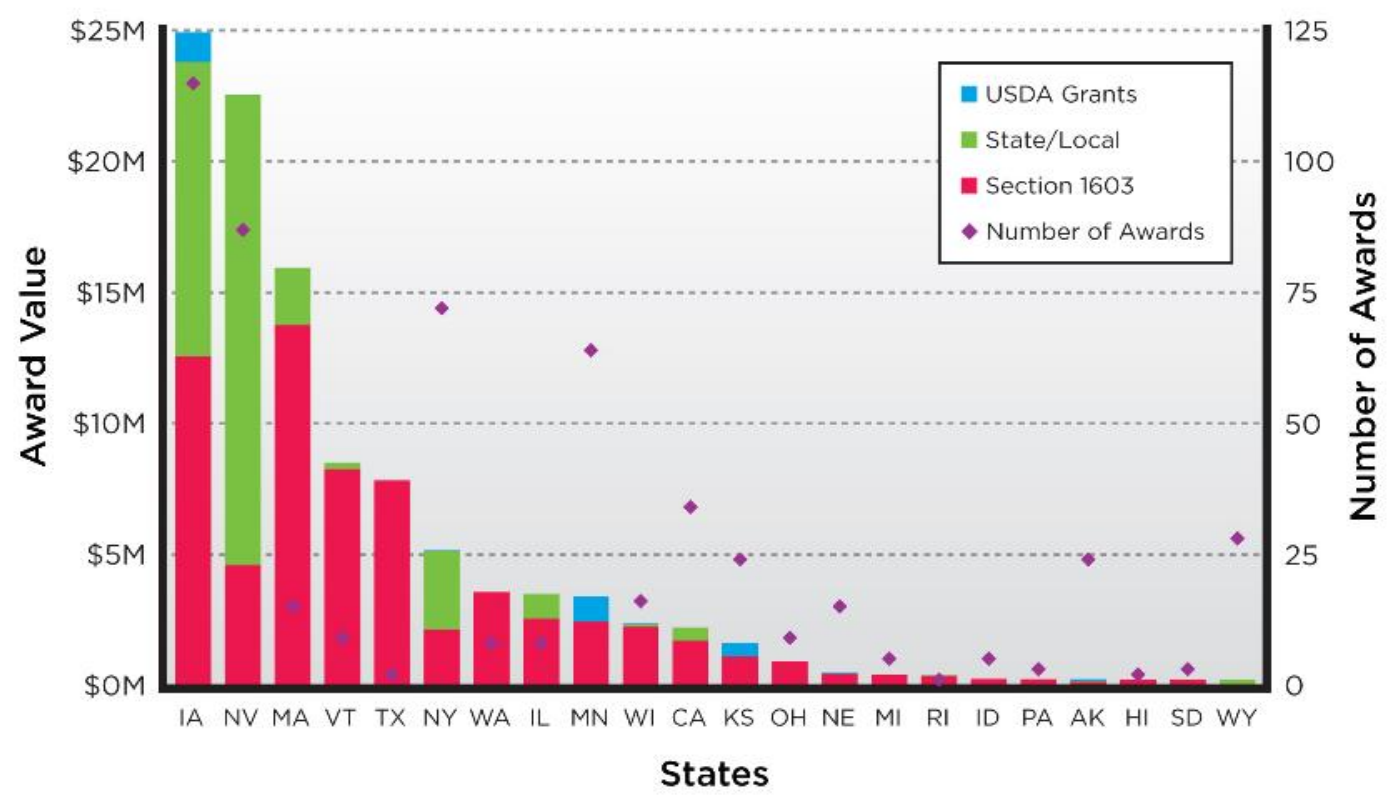

Figure 27. 2012 U.S. Distributed Wind Federal and State/Local Funding Awards

\subsection{Status of Incentives Available in 2012}

The distributed wind market is strongly influenced by frequent modifications and eliminations of various federal, state, and local policies and incentives. Figure 28 presents an overview of the policies and incentives available for wind projects in 2012, with each marker representing a distinct policy or incentive (often limited to a local jurisdiction or utility) for which the Database of State Incentives for Renewables and Efficiency (DSIRE) maintains a record. The incentive programs vary widely with respect to the amount of funding they provide, the total number of projects they support, and the length of time they are available. Circle markers in Figure 28 represent programs that were available in 2012 , but have since ended. ${ }^{11}$ Several new programs for wind that launched in 2013 are not shown. ${ }^{12}$

\footnotetext{
${ }^{11}$ One federal incentive (U.S. Department of Treasury Section 1603 payments) and 19 state and local programs are no longer available: Arkansas' Energy Technology Revolving Loan Fund, deactivated in late 2012; California's
} 


\subsection{Federal Policies and Incentives}

The main 2012 federal incentives applicable to distributed wind projects, explained in the sections below, included the Business Energy ITC and the Residential Renewable Energy Tax Credit, Section 1603 payments, and the USDA REAP grants and loans. Other incentives available to distributed wind projects include the Production Tax Credit (PTC), New Market Tax Credits, and Qualified Energy Conservation Bonds.

\subsubsection{Federal Production Tax Credit and Investment Tax Credit}

The federal PTC, the primary federal incentive for utility-scale wind, expired December 31, 2012, but in January 2013, the U.S. Congress extended the deadline by one year to December 31 , 2013 and revised the previous requirement that wind projects must be operational by the deadline to qualify for the credit to wind projects must start construction by the deadline. The Internal Revenue Service (IRS) has defined starting construction as starting physical work of a significant nature or incurring 5\% of the total project cost (IRS 2013). The Business Energy ITC was also revised to require start of construction by December 31, 2013 for eligibility for wind turbines larger than $100 \mathrm{~kW}$. Both the Business Energy ITC and the Residential Energy Tax Credit are available for small wind turbines up to $100 \mathrm{~kW}$ placed in service on or before December 31, 2016.

Most distributed wind projects do not use the PTC because an additional condition of the credit is that the electricity generated from the project must be sold to a third-party. However, some distributed wind projects, such as those providing power to manufacturing plants or schools, are structured so that an IPP owns and operates the onsite project and sells the power directly to the plant or school; therefore these projects qualify for the PTC.

\footnotetext{
Emerging Renewables Program, suspended in July 2012; Boulder County's (Colorado) ClimateSmart Loan Program; Southeast Colorado Power Association's Renewable Energy Rebate; Connecticut's On-Site Renewable DG Program; Delaware's Home Performance with Energy Star Loans; Indianapolis Power \& Light's Renewable Energy Production Rate; Kansas' Revolving Loan Program; Efficiency Maine's Small Business Loan Program; Massachusetts' Green Communities Grant Program; Michigan's Alternative Energy Personal Property Tax Exemption; Duke Energy's (North Carolina and South Carolina) Standard Purchase Offer for RECs; Pennsylvania's Green Energy Loan Fund; Rhode Island's Renewable Energy Fund Grant and Loan Programs; South Dakota's Wind and Transmission Construction Tax Refund; Texas' Renewable Energy Demonstration Pilot Program; U.S. Virgin Islands' WISE Program; and Xcel Energy's (Wisconsin) Experimental Advanced Renewable Energy Purchase Service.

${ }^{12}$ New programs available for wind in 2013 include: the federal Qualifying Advanced Energy Manufacturing Investment Tax Credit (inactive for several years); Arkansas' Property Assessed Clean Energy (PACE) financing no technologies specified; Los Angeles Department of Water and Power feed-in tariff (FIT) Program (available since February 2013); Colorado Springs Utilities Renewable Energy Rebate Program (not available to wind until 2013); Connecticut Light \& Power and United Illuminating Company Small Zero Emission Renewable Energy Credit Tariffs; Iowa Economic Development Authority Energy Bank Revolving Loan Program; Central Lincoln People's Utility District (Oregon) Renewable Energy Incentive Program; and Utah's Local Options for Commercial PACE Financing and Industrial Facilities \& Development Bonds.
} 


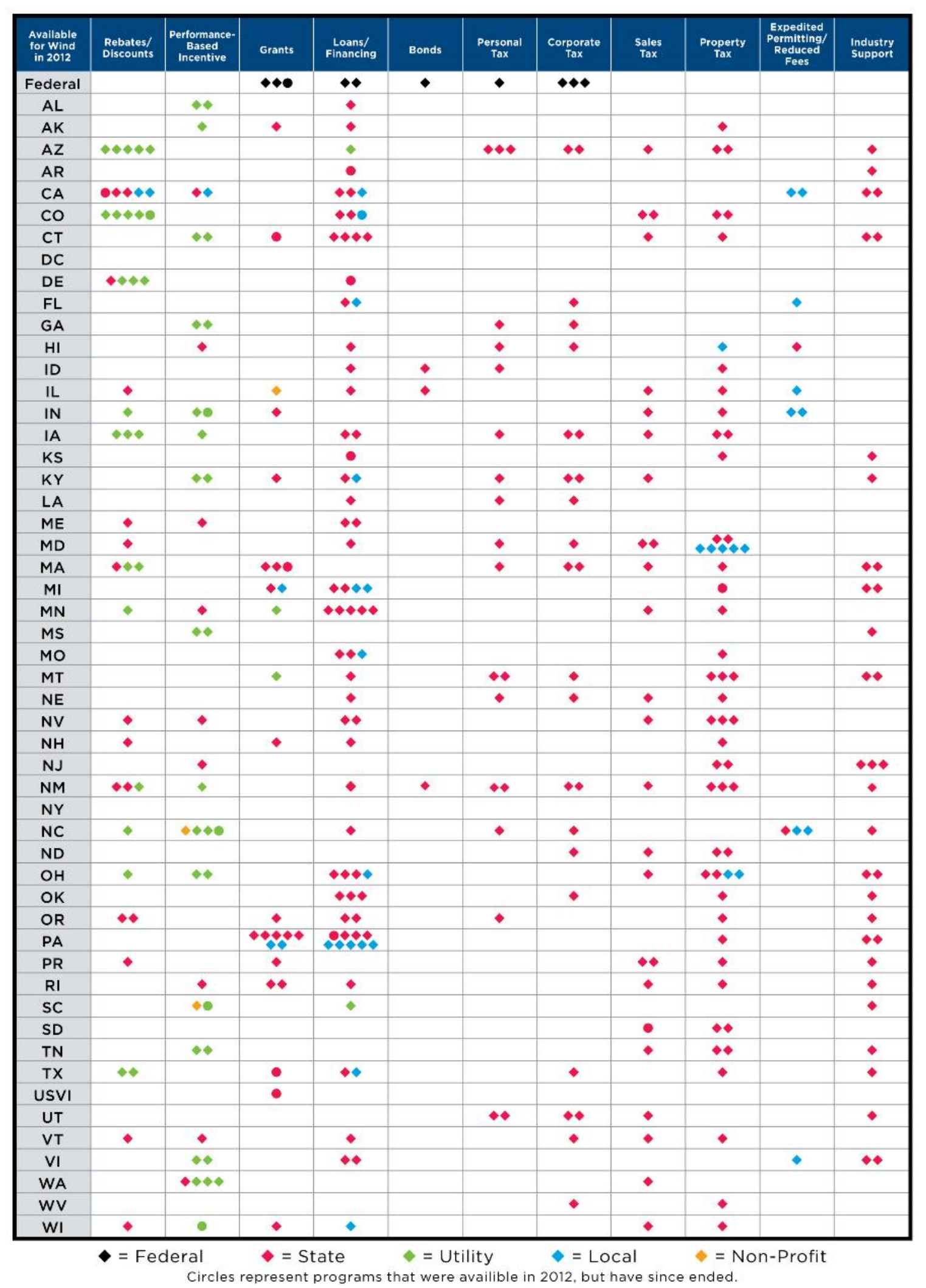

Figure 28. Wind Incentives Available in 2012 


\subsubsection{U.S. Treasury Section 1603 Payments}

The federal Business Energy ITC (26 USC § 48) provides a 30\% credit against the capital costs of a project, once the project is placed in service. The ITC is available for wind projects up through $100 \mathrm{~kW}$ through 2016, and for larger wind projects starting construction by December 31, 2013. The ITC was temporarily expanded to allow for cash payments in lieu of the tax credit, otherwise known as Treasury cash grants or Section 1603 payments. In order to qualify for the payment, wind power projects must have been under construction by the end of 2011, must have applied for a grant by October 1,2012, and must have been placed in service by the end of 2012. These cash payments expired December 31, 2012.

As of February 14, 2013, 201 distributed wind projects received almost $\$ 63$ million in Section 1603 payments in 2012 (Treasury 2013). These projects represent an estimated $\$ 220$ million in total capital investment across 30 states and the U.S. Virgin Islands.

\subsubsection{USDA REAP Grants and Loans}

The USDA REAP provides financial assistance to agricultural producers and rural small businesses to purchase, install, and construct renewable energy systems, along with other energy efficiency and renewable energy endeavors. Loan guarantees are issued for up to $75 \%$ of the project's cost, or a maximum of $\$ 25$ million. Grants are issued for up to $25 \%$ of the project's cost, or a maximum of $\$ 500,000$ for renewable energy projects.

In 2012, USDA REAP provided funding to 57 distributed wind projects; 54 received grants, 6 received loan guarantees, 2 received both a grant and a loan guarantee, and 1 received a grant for a feasibility study (Crooks 2013, USDA 2013). This funding totaled over $\$ 2.6$ million in grants and $\$ 1.4$ million in loan guarantees for distributed wind projects in 12 states and the U.S. Virgin Islands with an estimated total capital investment of over \$19 million.

This 2012 funding amount was more than the $\$ 1.7$ million in USDA grants provided for wind in 2011, but significantly down from the $\$ 8.5$ million provided in 2010 (AWEA 2012).

\subsubsection{New Markets Tax Credits and Qualified Energy Conservation Bonds}

Despite the sluggish economic recovery and the expiration of the Section 1603 program, a number of distributed wind project developers have employed seldom-used, but nonetheless valuable tools to create innovative financing structures to fund their projects. New Market Tax Credits (NMTCs) and Qualified Energy Conservation Bonds (QECBs) are two such examples that provided the necessary boost to attract private capital for several smaller-scale wind energy projects in 2012 .

The purpose of NMTCs is to promote private investment in low-income, economically distressed communities (Bolinger 2011). NMTCs work through specialized Community Development Entities (CDEs) that compete for and then offer federal tax credits in exchange for investments in 
local projects. NMTCs are not new, but have only been used to finance a few renewable energy projects. In essence, NMTCs provide an ITC (39\% over 7 years) for a Qualified Equity Investment $(\mathrm{QEI})$ in a CDE. The CDE directs virtually all of the $\mathrm{QEI}$ into a loan or equity investment for a qualifying low-income business. The tax credits are a permanent reduction of current and future tax liability and not a deferral of tax liability.

The 8-MW Junction Hilltop Wind project in Iowa (see Figure 29) qualified for NMTCs due to the area's declining population. In addition to NMTCs, the project received a Section 1603 payment and a loan from the state of Iowa. The project was commissioned in March 2012, is owned by two local farmers and seven relatives, cost $\$ 16.5$ million, uses five 1.6-MW GE turbines, and generates income for the farmers through a PPA.

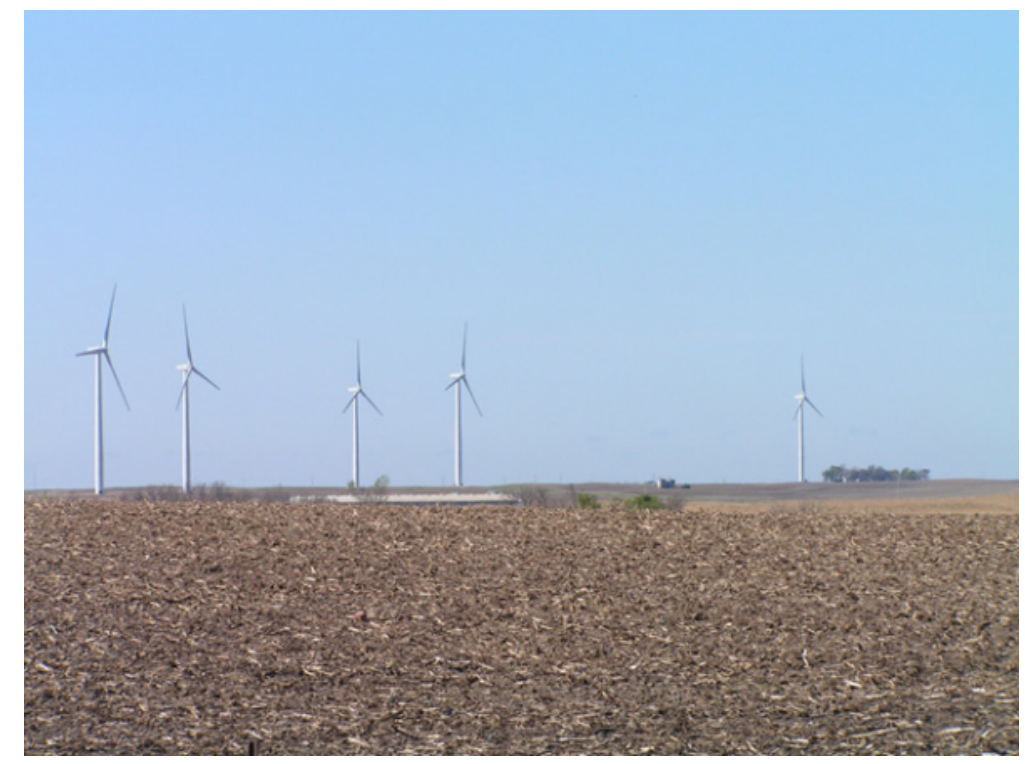

Figure 29. 8-MW Junction Hilltop Wind Project in Iowa (Photo credit: Tom Wind)

QECBs were established as part of the 2008 American Recovery and Reinvestment Act and expanded in 2009 to provide $\$ 3.2$ billion in issuance capacity (LBNL 2012a). The bonds enable qualified state, tribal, and local government issuers to borrow money at low rates to fund qualified energy conservation projects including energy efficiency, transportation, and distributed generation initiatives. However, a maximum of $30 \%$ of each state's QECB allocations may be used for private business activity (LBNL 2012b). A public entity can issue QECBs to finance qualified energy projects for a private user (e.g., a conduit issuance). QECBs are an attractive option because the U.S. Treasury subsidizes the issuer's borrowing costs, making QECBs one of the lowest-cost public financing tools available.

In 2012, two separate Massachusetts towns (Fairhaven and Scituate) issued QECBs to finance the construction of 1.5 and 3.0 MW distributed wind projects (Bellis 2012). In Washington State, the owners of a private reserve partnered with a Seattle-based design-build-operate-andmaintain firm to develop and construct the 4.5 MW Swauk Wind Project, which was partially financed through the issuance of QECBs by the Washington State Housing Finance Commission. 


\subsection{State Policies and Incentives}

Each state provides different types of incentives and policies for distributed renewable generation. These incentives and policies include net metering, rebates, tax credits, grants, and others, but do not always translate into strong distributed wind markets.

\subsubsection{State Incentive Funding}

Leading the states in small wind installations in 2012, Nevada provided approximately $\$ 18$ million in incentive funding to 78 different small wind turbines in agricultural, school, municipal, and residential applications through the RenewableGenerations program administered by NV Energy. Originally established in 2003, the program initially only included rebates for solar PV systems, but added wind to the program in 2008.

Another example of state incentive funding is California's Self-Generation Incentive Program. The incentive payment for this program is capped at $3 \mathrm{MW}$. While the program did not fund any distributed wind generation projects in 2012, its predecessor, the Emerging Renewables Program, provided approximately $\$ 500,000$ in incentive funding to 25 small wind projects totaling $169 \mathrm{~kW}$ in 2012, according to California Energy Commission records.

An example of an incentive program for mid-size and utility-scale distributed generation is the Massachusetts Commonwealth Wind Incentive Program, administered by the Massachusetts Clean Energy Center (MassCEC). The program provides grants for site assessments and feasibility studies and development grants and loans for both commercial and distributed projects that serve onsite loads at least $2 \mathrm{MW}$ in size. According to information from MassCEC, the program provided about $\$ 1.8$ million in funding to six distributed wind projects using utilityscale turbines totaling $12.5 \mathrm{MW}$ in 2012.

Iowa offers incentive programs that benefit mid-size and utility-scale turbines in distributed applications, namely the state's Alternate Energy Revolving Loan Program, and Renewable Energy Production Tax Credits. The Alternate Energy Revolving Loan Program offers nointerest loans for $50 \%$ of the project cost, up to $\$ 1$ million (DSIRE 2013). The Renewable Energy Production Tax Credits incentive offers a PTC of $1.5 \mathrm{k} / \mathrm{kWh}$, which can be applied toward the state's personal income tax, business tax, financial institutions tax, or sales and use tax (IUB 2013). The PTCs can also be transferred or sold to a third party, which creates another potential revenue source for a project.

These policies and incentives, along with Section 1603 payments, high Public Utility Regulatory Policies Act (PURPA) rates, and farmers' having ample cash available due to strong revenues from corn and other crops, made 2012 a banner year for distributed wind installations in Iowa. 


\subsubsection{Net Metering}

The concept of net metering allows consumers to offset their monthly electricity bills by producing their own energy, such as with a small wind system, and "spinning the meter backward" by sending excess energy generated onsite into the grid. How net metering programs are applied and how customers are compensated for this excess generation is evolving widely from state-to-state and utility-to-utility.

While utilities in all but a few states now offer some form of net metering, only 15 states (i.e., California, Delaware, Georgia, Hawaii, Louisiana, Maine, Maryland, Minnesota, Missouri, Nebraska, New Hampshire, Oregon, Vermont, Washington and West Virginia) have truly "statewide" net metering policies covering all types of public and private utilities (including rural electric cooperatives). Rural electric cooperatives in 9 additional states (i.e., Arizona, Arkansas, Kentucky, Michigan, New Mexico, Oklahoma, Utah, Virginia, and Wyoming) offer limited net metering. Figure 30 shows current capacity limits for each customer enrolled in a net metering program and which states have state-wide policies covering all utilities in the state, which have state-level policies for certain utility types only (often primarily urban areas), and which have only voluntary programs or no net metering policies.

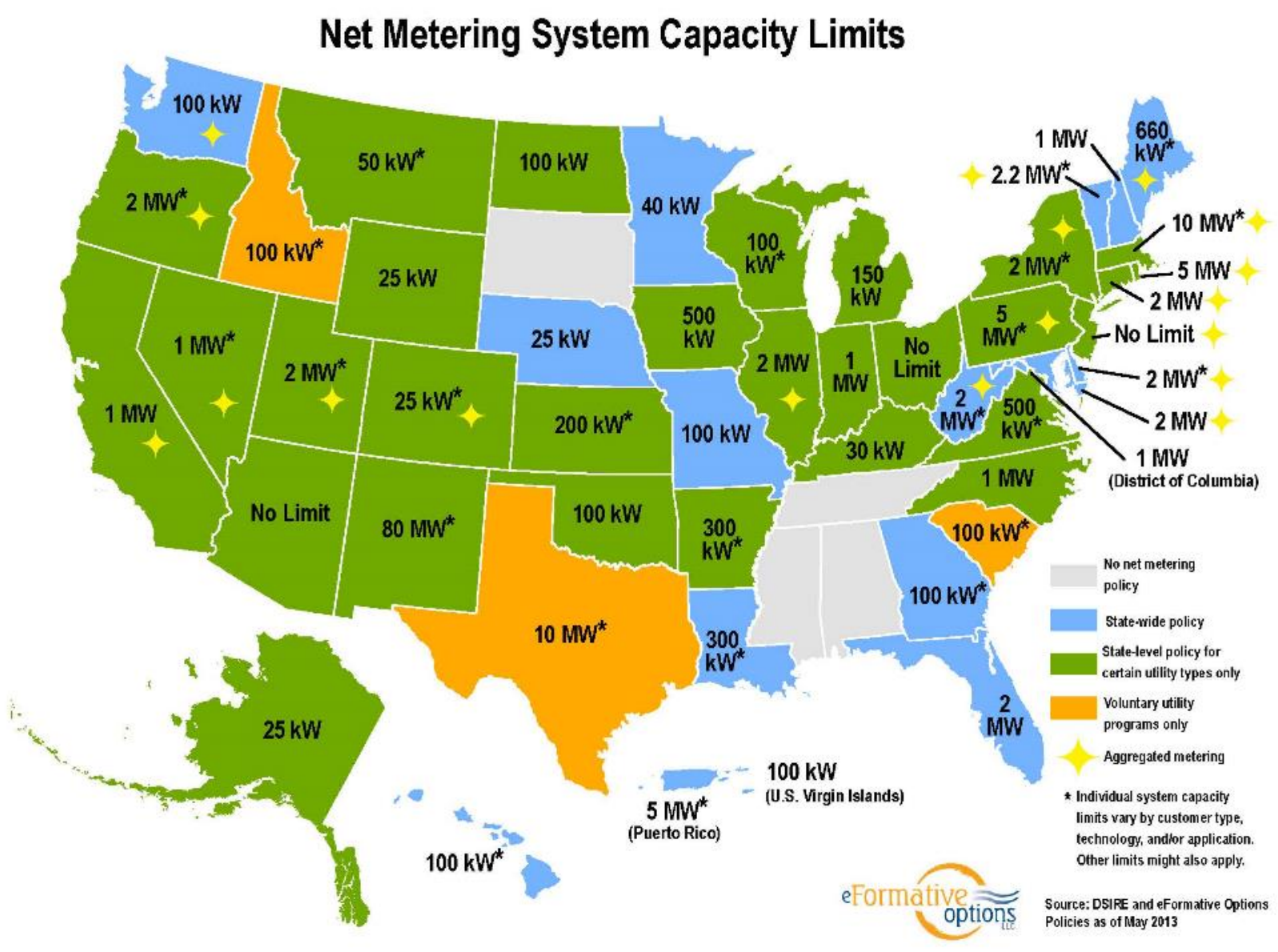

Figure 30. Net Metering State Policies 


\subsubsection{Meter Aggregation}

Numerous states recently expanded the scope of their net metering policies to allow additional customers to take advantage of both their onsite and offsite resources, addressing investment barriers for small and community-scale clean energy. In at least 20 states, some form of aggregated, remote, or group net metering is allowed which authorizes participants to combine meters and jointly benefit from an single net metered renewable system that is not directly connected to the customers' loads.

For example, in some cases a farmer can apply the wind generation near an irrigation system to a residence connected on a separate meter. Alternatively, multiple retail stores in a shopping mall may benefit from a single wind turbine installed in the parking lot. Allowing aggregation of multiple meters can ease the administrative burden of net metering for electric companies; facilitate grid stress relief; and, in a few limited cases, reduce the need for costly peak power when sited strategically. While true onsite generation avoids distribution costs and provides other values, allowing customers to consolidate meters broadens the geographic possibilities for local wind projects that can take advantage of wind resources more favorable than found directly at the site of the load. Some utilities are responding to the growth in customer generation by increasing monthly service charges and standby fees to recover fixed-grid costs, whereas others are reducing the allowed qualifying project size.

The Interstate Renewable Energy Council (IREC) recently issued an update to its Model Interconnection Procedures, based on evolving best practices and state rulemakings across the country, particularly in California, Hawaii, and Massachusetts. Interconnection reform has been triggered by rapid growth in distributed generation in key solar markets, such as California's Pacific Gas and Electric service territory, which alone interconnected more than 17,500 net metered systems (primarily PV) in 2012 (Passera 2013).

\subsubsection{Impact of Net Metering Policies}

While net metering policies typically are not primary market drivers for distributed wind on their own, they are seen as foundational in facilitating market growth and often crucial to a thriving distributed generation industry. IREC describes net metering and interconnection polices as "akin to renovating an old house - you can install granite countertops and new appliances but if you don't maintain the foundation, people probably won't want to move in."

Strong distributed wind markets do not always directly correlate to states with favorable net metering policies; however, most of the 2012 top states for distributed wind capacity allow net metering for systems up through $100 \mathrm{~kW}$ or larger and received high grades in the current edition of Freeing the Grid published by IREC and the Vote Solar Initiative (IREC and Vote Solar 2012).

For example, Iowa has had state-level net metering standards since 1984 allowing customers of all investor-owned utilities to net meter renewable energy systems with no explicit limit on 
system size or total enrollment. Since 2002, the net metering benefits have been limited to $500 \mathrm{~kW}$ per installation and municipal and cooperative utilities are not required to offer net metering. In 2010, Iowa standardized the interconnection procedures, which now apply to distributed generation facilities of up to $10 \mathrm{MW}$ and set four levels of review based on project size and complexity.

Massachusetts' net metering policy, extended from $65 \mathrm{~kW}$ up to $10 \mathrm{MW}$ through the 2008 Green Communities Act, has resulted in a strong positive benefit for distributed wind projects allowing credits to transfer to other customers, with municipalities being a key purchaser. In addition, Massachusetts' rules provide for "neighborhood net metering" which allows a group of 10 or more residential customers to offset their electric load through one shared system.

California's original net metering law was enacted in 1996, with all but one utility subject to current rules. Beginning in 2009, California was also one of the first states to allow "virtual" net metering which allows bill credits from a renewable energy system to be disbursed across more than one meter for multi-family affordable housing units and municipalities. More than 120,000 residential and non-residential accounts are enrolled in California's net metering program (CPUC 2013), and a 2012 California Public Utility Commission decision clarified 2010 legislation raising the aggregate limit to $5 \%$ of a utility's aggregate customer peak demand, defined as the sum of the non-coincident peak demands of all utility customers.

In contrast, distributed wind markets have remained active in Wisconsin and Texas in spite of limited net metering programs. The Wisconsin Public Service Commission first adopted net metering standards for investor-owned and municipal utilities in 1982 with a $20 \mathrm{~kW}$ limit, which was subsequently increased for some utilities - with enrollment limits - through rate cases. Wisconsin investor-owned utilities are seeking to move toward monthly true-ups (i.e., reconciling actual and billed usage) with excess generation credited at a very low avoided cost. For wind generation with seasonal production patterns that may not align with customer loads, this is creating significant project risk and uncertainty. In addition, Wisconsin's interconnection procedures require an external disconnect switch and additional insurance. While Texas does not have a state-level net metering policy, standardized interconnection procedures have been in place in the state since 1999 for systems up to $10 \mathrm{MW}$. External disconnect devices are required for all systems, but utilities are prohibited from requiring any pre-interconnection fees for systems less than $500 \mathrm{~kW}$.

Lacking or limited net metering and interconnection policies contribute to challenging market environments in several states with strong wind resources, including South Dakota, Idaho, Oklahoma, Montana, Alaska and New Hampshire. Although Minnesota was the first state in the nation to implement net metering in 1983, in recent years its dated requirements and 40-kW limit have posed market barriers for distributed wind, with no mid-size or utility-scale distributed wind projects installed in the state in 2012. New legislation in 2013 increased Minnesota's net metering limit to $1,000 \mathrm{~kW}$ for public utilities and added single-customer meter aggregation; this legislation is expected to help revitalize the state's dampened distributed generation industry. 


\section{Distributed Wind Policy Comparison Tool}

To aid stakeholders in identifying the best financial environments for distributed wind turbines and which existing and potential policy combinations have the most impact on improving project economics, DOE funded eFormative Options to create the Distributed Wind Policy Comparison Tool (windpolicytool.org).

The tool presents each state's current policy environment for a variety of sectors, turbines, and wind resources, and allows stakeholders to examine a wide range of policy combinations to help them make informed decisions that can support distributed wind market growth. State incentive calculations are based on a data feed from the DSIRE.

Numerous new features and updates have improved the tool since its initial launch in 2011, including an enhanced interface that increases usability, pop-up definition windows, updated turbine pricing and performance data, and regular updates to the incentive information as states frequently change and restructure their incentive programs.

The Distributed Wind Policy Comparison Tool allows for "what if" scenario analysis, such as what feed-in tariff (FIT) rates impact the economics of distributed wind turbines most effectively. FITs are policies that aim to support the development of renewable energy projects by offering long-term contracts and fixed prices for renewable-generated electricity. Currently Hawaii, Vermont, and Rhode Island offer FIT programs, but the tool allows users to explore the impacts FITs could have in other states as well.

With increased pressure on state budgets, wind energy incentive programs have been unstable in recent years, and several states have scaled back or eliminated funding. The following are two examples that demonstrate how the Distributed Wind Policy Comparison Tool can reveal financial impacts, specifically cost of energy (COE) impacts, from policy changes.

In April 2011, Colorado had a capacity-based, flat-rate rebate for wind turbines. The incentive provided $\$ 3,000$ per $\mathrm{kW}$, with a $5 \mathrm{~kW}$ size limit for residential applications and a $50 \mathrm{~kW}$ size limit for commercial applications. Introduced in 2010, this program funded at least 36 small wind turbines totaling $90 \mathrm{~kW}$, but was discontinued as of September 1, 2011. While a few small wind turbines in the state have since received U.S. Department of Agriculture and U.S. Treasury Section 1603 payments, the elimination of the state rebate increased the COE of small wind turbines in Colorado and made projects there less economic, as shown in the table below for an example $5.4 \mathrm{~kW}$ residential project

In September 2012, Vermont restructured its long-established small wind incentive program from a capacitybased, incremental rate rebate to a hybrid model that offers a capacity-based, flat-rate rebate with a productionbased per kWh payment as well. Previously, turbines up through $100 \mathrm{~kW}$ in size were eligible, but the current program limits incentives to turbines sized $10 \mathrm{~kW}$ or less. Thus the COE of the $12 \mathrm{~kW}$ example project in the table below rose dramatically, while the COE of the $8.9 \mathrm{~kW}$ turbine was unaffected. The program stopped accepting applications in January 2013 but reopened as of March 13, 2013 with \$2 million in funding available for PV, solar hot water, and small wind systems. Vermont's various incentive structures have provided funding to 122 turbines totaling $733 \mathrm{~kW}$ over the past 9 years.

\begin{tabular}{ccccccc}
\hline & \multicolumn{2}{c}{ Colorado } & \multicolumn{2}{c}{ Vermont } & \multicolumn{2}{c}{ Vermont } \\
\cline { 2 - 7 } & \multicolumn{2}{c}{$5.4 \mathrm{~kW}$ Residential } & \multicolumn{2}{c}{$12 \mathrm{~kW}$ Residential } & \multicolumn{2}{c}{$8.9 \mathrm{~kW}$ Residential } \\
\cline { 2 - 7 } $\mathrm{COE}$ & April 2011 & March 2013 & April 2011 & March 2013 & April 2011 & March 2013 \\
& $25.5 \phi / \mathrm{kWh}$ & $31.0 \phi / \mathrm{kWh}$ & $18 \phi / \mathrm{kWh}$ & $39 \phi / \mathrm{kWh}$ & $22.6 \phi / \mathrm{kWh}$ & $22.1 \phi / \mathrm{kWh}$ \\
\hline
\end{tabular}




\subsection{Business Trends}

Business trends in the 2012 U.S. distributed wind market were dominated by the status of the Section 1603 program and ITC discussed in Section 6 of this report, as well as the changing U.S. economy in the wake of the 2008 recession and the associated challenges obtaining loans for project development. Emerging trends included large growth in refurbished wind turbines and ongoing exports from U.S. small wind manufacturers. Developments in 2012 included the official accreditation of the Small Wind Certification Council (SWCC) and the issuance of the Distributed Wind Energy Association's model ordinance guidelines and the U.S. Fish and Wildlife Service's (FWS) Final Land-Based Wind Energy Guidelines (FWS 2012).

\subsection{Solar PV Market}

The solar PV market provides a point of comparison for the distributed wind market. The U.S. solar market continued to grow rapidly in 2012. Each PV market segment - residential, nonresidential, and utility - grew in capacity 62\%, 26\%, and 134\%, respectively, compared to 2011. The total PV capacity installed in 2012 was 3,313 MW, and of that, residential accounted for $488 \mathrm{MW}$; non-residential for 1,043 MW; and utility for 1,781 MW. These capacity additions in 2012 alone represented approximately $46 \%$ of the cumulative total installed PV capacity in the United States (GTM and SEIA 2013a).

\subsubsection{Pricing and State Policies}

The national weighted average price for solar modules declined $26.6 \%$, from $\$ 4.10 / \mathrm{W}$ in 2011 to $\$ 3.01 / \mathrm{W}$ in 2012 (GTM and SEIA 2013a). This development contributed to residential PV system prices falling $18.1 \%$ (from $\$ 6.16 / \mathrm{W}$ to $\$ 5.04 / \mathrm{W}$ ); non-residential system prices falling $13.3 \%$ (from $\$ 4.65 / \mathrm{W}$ to $\$ 4.27 / \mathrm{W}$ ); and, utility system prices falling about $33 \%$ (from $\$ 3.20 / \mathrm{W}$ to $\$ 2.27 / \mathrm{W})$. In addition, solar component prices declined significantly.

Primarily driven by renewable portfolio standard (RPS) policies, lower project costs, electricity prices and rate structures, and the federal ITC, PV continued to have significant market presence in states such as California and New Jersey. Arizona's 62\% growth in utility-scale capacity pushed its total installed capacity past New Jersey for the first time into second behind California. In fact, utility-scale PV projects were the fastest growing PV market segment and represented over $50 \%$ of the total installed capacity in California, Arizona, Nevada, North Carolina, New Jersey, Texas, and Illinois (GTM and SEIA 2013a). Otherwise, significant residential PV market growth in Hawaii fell just behind California's lead.

Some states (i.e., California, Colorado, Massachusetts, Nevada, New York, and Texas) saw installed capacity increases in both PV and distributed wind. However, several states (i.e., Alaska, Iowa, Minnesota, and Kansas) with the most installed distributed wind capacity lacked parallel growth in PV. Areas without state, local, or utility incentives or policy mandates 
continued to see relatively few PV installations, as federal incentives alone were generally insufficient to create strong PV markets.

Further, PV installation labor, balance-of-system costs, and overhead continued to decrease, indicating success of state and federal policies in driving down costs (Colville 2012). As a result of the lower per-watt costs, the average size of direct cash incentives for PV from states and utilities, and the dollar-per-watt value of the federal tax incentive have continued to decrease.

Improved capital markets, third-party financing, community-purchase projects, and state renewable portfolio requirements with solar mandates were major PV market drivers in 2012.

\subsubsection{U.S. Manufacturer Share and Import Tariffs}

While the distributed wind industry largely builds to order and does not maintain year-round full production capacity, PV modules are produced to supply ongoing inventory levels. U.S. PV manufacturer sales represented just 11\% (GTM and SEIA 2013a) of the global PV market as U.S. manufacturers continued to face stiff competition due to global supply outpacing demand. The downward global pressure on average system prices drove prices below costs for some suppliers, causing industry turbulence. The global oversupply of PV modules benefited customers, but caused a ripple effect with some consolidation among solar manufacturers worldwide.

The U.S. International Trade Commission's final ruling in the anti-dumping and countervailing duty complaints brought by U.S. PV manufacturers against Chinese crystalline silicon (c-Si) manufacturers had limited effect on prices as the cost of c-Si and PV panels in the United States continued to decline despite U.S. tariffs ranging from $24 \%$ to $250 \%$ on Chinese products (Andrew 2013). However, 2012 silicon PV cell and module imports from China to the United States declined around 33\% from 2011 (U.S. Census Bureau 2013).

Similarly, Chinese wind turbine manufacturers have gained an increasing share of the global market, and while historically the majority of that growth has been due to domestic sales, more and more turbines are being exported into the international market —including the United States. In 2012 China's share of the tower import market was almost 50\% (Wiser 2013); however, as with PV, a ruling came from the U.S. Commerce Department to impose additional duties on Chinese towers imported into the United States. It is yet to be seen how this will affect the U.S. distributed wind industry.

\subsubsection{SunShot Initiative}

DOE's SunShot Initiative awarded more than $\$ 95$ million for concentrating solar power and PV in fiscal year 2012, nearly doubling the number of projects focused on reducing hardware and balance-of-system costs, increasing reliability, and spurring rapid adoption of solar technology. Balance-of-system hardware includes all non-module components used in solar power installation for residential, commercial, and utility markets and represents a major opportunity to 
achieve significant cost reductions. The SunShot Initiative aims to decrease the total costs of solar energy systems by $75 \%$ by the end of this decade, and has resulted in a number of jurisdictions reducing fees and streamlining permitting processes for both solar and wind systems.

Declining prices of PV systems and the availability of PV incentives have provided a competitive option for customers interested in distributed renewable generation. As a result, fewer distributed wind projects are being installed in some states.

\subsection{Small and Mid-Size Turbine Certification}

Signaling a maturing industry, several additional small wind turbine models have achieved certification in the past year. The SWCC became an accredited certification body, and testing activities for both small and mid-size turbines have accelerated. The SWCC, along with Intertek (a Regional Test Centers [RTC] partner and accredited test and certification body) and other nationally recognized testing laboratories, are having a significant influence on the distributed wind industry. These organizations provide wind turbine buyers with reliable third-party verification of important safety, acoustic, and performance data and provide wind turbine sellers the capacity to demonstrate compliance with regulatory and incentive program requirements.

As of the end of 2012, formal certification testing to the AWEA Standard 9.1-2009 ${ }^{13}$ had been conducted or completed for 28 small wind turbine models seeking to sell to the U.S. market, including 6 through the DOE-National Renewable Energy Laboratory (NREL) RTC project. In addition, in 2012 at least three mid-size wind turbine manufacturers performed testing according to IEC 61400 Standards for use in accessing U.S. incentives. Four RTCs, in New York, Texas, Utah and Kansas, supported by DOE and NREL advanced in 2012, and the Small Wind Association of Testers (SWAT) held a series of five webinars archived on the NREL website in preparation for its first international conference in 2012 hosted by Intertek in Ithaca, New York.

As of the end of 2012, power performance certification ratings to the AWEA Standard were issued for five small wind turbine models, four of which were fully certified with sound level ratings and design and duration test compliance (Table 6). In 2012, SWCC also issued provisional certifications to five other models, including four tested and analyzed in the UK. Intertek completed testing to the AWEA Standard on three additional turbine models in 2012, and issued certificates for the UK Microgeneration Certification Scheme for three others.

Wind turbines eligible for certification to the AWEA Small Wind Turbine Performance and Safety Standard 9.1-2009 are electricity-producing with a swept area up to $200 \mathrm{~m}^{2}$, which corresponds to a rotor diameter of about $16 \mathrm{~m}$. Depending on the turbine design, this maximum size is a turbine producing about 50 to $65 \mathrm{~kW}$. Both horizontal-axis wind turbines (HAWTs) and

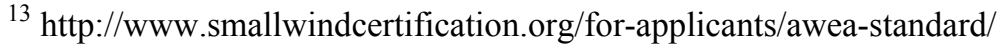


vertical-axis wind turbines (VAWTs) are eligible to apply for certification, as are both grid-tied and off-grid models. To date, only grid-tied HAWTs have completed the process in the United States, although a few VAWTs have started the certification testing process, and one VAWT (the QR 5 model) has been certified in the UK.

Table 6. Small Wind Turbine Certification Ratings Issued or Renewed in 2012

\begin{tabular}{|c|c|c|c|c|c|}
\hline Applicant & $\begin{array}{c}\text { Bergey } \\
\text { Windpower }\end{array}$ & $\begin{array}{l}\text { Endurance } \\
\text { Wind } \\
\text { Power }\end{array}$ & $\begin{array}{l}\text { Evance } \\
\text { Wind } \\
\text { Turbines }\end{array}$ & $\begin{array}{l}\text { Southwest } \\
\text { Windpower }\end{array}$ & $\begin{array}{l}\text { Sonkyo } \\
\text { Energy }\end{array}$ \\
\hline Turbine & Excel 10 & $\begin{array}{c}\text { Endurance } \\
\text { S-343 }\end{array}$ & $\begin{array}{l}\text { Evance } \\
\text { R9000 }\end{array}$ & $\begin{array}{c}\text { Skystream } \\
3.7\end{array}$ & $\begin{array}{c}\text { Windspot } \\
3.5\end{array}$ \\
\hline $\begin{array}{l}\text { Rated Annual Energy @ } 5 \mathrm{~m} / \mathrm{s} \\
\text { Estimated annual energy production } \\
\text { assuming an annual average wind } \\
\text { speed of } 5 \mathrm{~m} / \mathrm{s}(11.2 \mathrm{mph}) \text {, a Rayleigh } \\
\text { wind speed distribution, sea-level air } \\
\text { density, and } 100 \% \text { availability. Actual } \\
\text { production will vary depending on site } \\
\text { conditions. }\end{array}$ & $\begin{array}{l}13,800 \\
\mathrm{kWh}\end{array}$ & $8,910 \mathrm{kWh}$ & $9,160 \mathrm{kWh}$ & $3,420 \mathrm{kWh}$ & $4,824 \mathrm{kWh}$ \\
\hline $\begin{array}{l}\text { Rated Sound Level } \\
\text { The sound level that will not be } \\
\text { exceeded } 95 \% \text { of the time, assuming an } \\
\text { annual average wind speed of } 5 \mathrm{~m} / \mathrm{s} \\
(11.2 \text { mph), a Rayleigh wind speed } \\
\text { distribution, sea-level air density, } \\
100 \% \text { availability and an observer } \\
\text { location } 60 \mathrm{~m}(\sim 200 \mathrm{ft}) \text { from the rotor } \\
\text { center. }\end{array}$ & $42.9 \mathrm{~dB}(\mathrm{~A})$ & $\begin{array}{l}\text { Pending } \\
\text { full SWCC } \\
\text { certification }\end{array}$ & $45.6 \mathrm{~dB}(\mathrm{~A})$ & $41.2 \mathrm{~dB}(\mathrm{~A})$ & $39.1 \mathrm{~dB}(\mathrm{~A})$ \\
\hline $\begin{array}{l}\text { Rated Power @ } 11 \text { m/s } \\
\text { The wind turbine power output at } 11 \\
\text { m/s }(24.6 \text { mph) at standard sea-level } \\
\text { conditions. }\end{array}$ & $8.9 \mathrm{~kW}$ & $5.4 \mathrm{~kW}$ & $4.7 \mathrm{~kW}$ & $2.1 \mathrm{~kW}$ & $3.2 \mathrm{~kW}$ \\
\hline
\end{tabular}

For turbines with rotor swept areas larger than $200 \mathrm{~m}^{2}$ designated by international standards as "medium-sized," SWCC recently began offering performance certification confirming that performance testing of the turbine conforms with the requirements identified in IEC 61400-12-1 (Power Performance) and IEC 61400-11 (Acoustics). In addition, both the SWCC and Intertek are working with other certification programs in Europe, Asia, and North America to minimize variations in country-specific requirements and provide access to international markets for turbines manufactured in the United States. Intertek also began testing for purposes of providing Type Certification for mid-size turbines in 2012 and was granted accreditation for IEC testing and certification by International Accreditation Service.

DOE is on track to reach its programmatic goal of 40 turbine designs certified by 2020 . Initial DOE milestones of 12 models certified in the federal fiscal years 2012 and 2013 were met early, representing a significant share of the North American distributed wind market. Certification is helping to prevent unethical marketing and fraudulent claims, ensuring consumer protection, and 
building the distributed wind industry's credibility. Certified ratings are allowing purchasers to directly compare products and funding agencies and utilities to gain greater confidence that small and mid-size turbines installed with public assistance have been tested for safety, function, performance, and durability and meet requirements of consensus standards.

\subsection{Unified List for Incentive Eligibility}

In 2012, the Clean Energy States Alliance, through its Interstate Turbine Advisory Council (ITAC), released and subsequently updated a national unified list of small and mid-size wind turbines eligible for incentive funding from ITAC state and utility member programs.

In addition to requiring certification for small wind turbines, ITAC reviews manufacturers' consumer and dealer services, marketing consistency with third-party testing, turbine operational history, turbine warranty, and manufacturers' response to technical problems, failures, and customer complaints. As a collaborative and common inventory of turbines, the unified list assures customers that tax- or rate-payer funding fully supports the installation of reliable and safe technology as well as enables improvements in program consistency, transparency, and benefits.

Currently, seven programs are members of ITAC: California Energy Commission; California Public Utilities Commission; Energy Trust of Oregon; MassCEC; New Jersey's Clean Energy Programs; NYSERDA; and NV Energy. Two other programs participate in ITAC strategy meetings: Minnesota Department of Commerce Division of Energy Resources and Wisconsin's Focus on Energy. In addition to the ITAC-participating agencies, the Vermont Clean Energy Development Fund and the Maryland Energy Administration Windswept Grant Program also require either SWCC certification or previous program qualification for incentive eligibility.

For wind turbines with a swept area between 200 and $1,000 \mathrm{~m}^{2}$, ITAC and its members require certification to applicable parts of IEC 61400 from an accredited, independent certification body, with an option for evidence of extensive operational history in lieu of certified design evaluation, and several non-technical items including resolution of any customer or contractor complaints.

\subsection{Financing Issues}

The 2008 recession and the U.S. economy's slow recovery have strained financing of clean energy by U.S. banks. Acknowledging the barrier of high upfront costs for many consumers wishing to purchase wind turbines for distributed applications, the industry emphasized a need for construction bridge loans and long-term loans at attractive rates. Industry leaders continue to encourage financing, just as most home improvements and large commercial equipment purchases are financed.

The distributed wind industry recognizes that improved financing packages are urgently needed to aid U.S. market growth and that tax credits and performance incentives alone do little to 
reduce upfront costs and often require at least short-term additional support. A growing number of finance partners are showing interest in the sector with at least one company (United Wind) working to offer lease arrangements and several additional state clean energy funds considering launching revolving loan programs.

\subsection{Permitting Issues}

Public leaders, policymakers, and wind industry stakeholders continue to work collaboratively to improve permitting processes that support the development of affordable and safe wind energy projects that respect property rights and promote economic growth.

\subsubsection{Model Zoning Ordinance Expanded}

In 2012, building on a Wind Energy Guide for County Commissioners available from the National Association of Counties (NACo 2006) and other past work to assist county leaders in learning about distributed wind systems and developing effective county wind ordinances, the Distributed Wind Energy Association (DWEA) published a model ordinance and guidelines to lead local governments through the process of adopting solid and defensible wind turbine ordinances for distributed applications. While the original ordinance covered only small wind systems (up through $100 \mathrm{~kW}$ ), an expanded version also covers larger distributed projects that generate and use energy onsite. The model ordinance is intended to "promote the safe, effective, and efficient use" of distributed wind energy systems installed to reduce the onsite consumption of utility-supplied electricity" and encourage responsible and safe installations with proper siting and tower heights (DWEA 2013). It is provided as a resource for counties, towns, municipalities, jurisdictional and neighborhood associations, state and federal incentive agencies, wind turbine installers, property owners, advocates and others to serve as a guide to facilitate small and distributed wind energy development.

The most significant aspect of the model ordinance is the categorization of small wind turbines as a permitted use, significantly streamlining the zoning and permitting process. According to DWEA, this not only allows for reduced time and cost to the jurisdictional authority, but also avoids the addition of unnecessary, non-value-added cost to property owners wishing to install small wind turbines. DWEA maintains that a permitted use is the preferred and most appropriate category in almost all cases.

The DWEA model ordinance defines best practices for turbine siting while ensuring that neighbor property rights and safety concerns are addressed. Its criteria address common issues such as sound, tower height, setbacks, decommissioning, and compliance with building, electrical, and Federal Aviation Administration codes and regulations. In addition, the ordinance recommends that turbines comply with national certification and that the permissive zoning represented only be extended to third-party certified small wind turbines in compliance with national and international standards. Non-compliant wind turbines should be subject to greater scrutiny and/or restrictions. DWEA members including installers, manufacturers, and educators 
from across the country drafted the ordinance after consulting with administrators, planning commissioners, city attorneys, and turbine owners.

\subsubsection{Siting Guidelines to Avoid Wildlife Impacts}

The FWS released its Final Land-Based Wind Energy Guidelines (FWS 2012) in March 2012 to help wind energy project developers avoid and minimize impacts of land-based wind projects on wildlife and their habitats. The guidelines were designed to assist developers in recognizing situations where wildlife may be affected by a proposed project. A tiered approach laid out in the FWS Guidelines suggests questions a developer might use in evaluating the potential risk associated with developing a project at a given location. The guidelines are voluntary and designed for use by utility-scale, land-based wind energy projects.

For distributed wind developers investigating potential project sites, the general principles of the tiered approach can be used to assess and reduce potential impacts to wildlife, including answering the first tier of questions using publicly available information. In the vast majority of situations, appropriately sited small wind projects are not likely to pose significant risks to wildlife. For most small wind projects, the answers will likely preclude the requirement for conducting detailed preconstruction assessments or monitoring surveys typically called for in the second and third tier. However, by answering the first tier of questions, distributed wind project developers, as well as land owners, can determine the need to further communicate with FWS officials.

\subsection{Vertical-Axis Wind Turbines and Turbine Installations in the Built Environment}

U.S. 2012 sales of seven different VAWT models from three different manufacturers (two U.S.based and one Canadian) were reported totaling 104 units and 0.27 MW. These VAWTs accounted for less than 3\% of the total 2012 U.S. small wind unit sales and less than 2\% of 2012 U.S. small wind capacity. U.S. VAWT manufacturers exported 274 units totaling $0.6 \mathrm{MW}$ in 2012 , which represents less than 7\% of the total number of 2012 small wind units exported and less than $3 \%$ of 2012 exported small wind capacity.

Sales of seven HAWT models typically installed in rooftop applications were reported in 2012 from three manufacturers (two U.S.-based and one from the UK) totaling 223 units and $0.2 \mathrm{MW}$. These rooftop units comprise about $6 \%$ of the total 2012 U.S. small unit sales and 1\% of U.S. small wind capacity. U.S. rooftop wind turbine manufacturers exported 352 units totaling $0.4 \mathrm{MW}$, which is about $9 \%$ of the total number of 2012 small wind units exported and less than $2 \%$ of 2012 exported small wind capacity.

Although VAWTs and rooftop-mounted turbines appeal to consumers, these applications face challenges. 
Presently, VAWT system modeling and certification are an industry challenge mainly because although the current certification standards may be applied to both HAWTs and VAWTs, aspects that are more specific to VAWTs (e.g., blade fatigue, strut connections, unsteady aerodynamics, dynamic stall, and precession dynamics) are not fully addressed. NREL, funded by DOE, is working on developing open-source small VAWT modeling tools and is conducting research to further inform the standards to help U.S.-based small wind turbine manufacturers and certifiers reach higher levels of product safety and reliability (Jain et al. 2013).

In a built (urban) environment, winds can be unpredictable and turbulent as wind flows are interrupted and redirected by buildings and other structures. In addition, urban environments tend to have lower wind resources and are therefore often not suited for wind turbine installations of any kind. As a result, rooftop wind turbines frequently underperform with respect to generation expectations, causing dissatisfaction among consumers (Smith et al. 2012). The distributed wind industry and DOE continue to look for ways to address the issues faced by wind turbines in built environments.

\subsection{Supply Chain}

The U.S. distributed wind energy supply chain contains more than three dozen facilities: at least 21 with active assembly of distributed wind turbines, 7 manufacturing distributed wind turbine blades, 6 producing distributed wind turbine towers, and 3 producing drive trains and other component for distributed wind turbines, spread across 17 states (i.e., California, Colorado, Florida, Kansas, Michigan, Minnesota, Nebraska, New York, Ohio, Oklahoma, Oregon, Pennsylvania, South Carolina, Texas, Vermont, Washington, and Wisconsin). This is in addition to numerous other aspects of the distributed wind supply chain, including all of the parts and services included in manufacturing, installing, and maintaining small, mid-size and distributed utility-scale wind turbines. No 2012 sales were reported from an additional 9 small wind turbine manufacturing facilities in five states (California, Massachusetts, Michigan, Nevada, and Ohio), and three manufacturing facilities have closed in recent months (in Arizona, Kansas, and Washington).

Similar to the utility-scale wind industry, employment in the U.S. distributed wind energy industry includes jobs across a wide variety of sectors seen in most major capital-intensive and heavy manufacturing industries, including:

- development: site selection, siting and permitting, biology and ecology, real estate, land agents, resource assessment, and incentive qualification

- engineering: civil, mechanical, and electrical

- construction: general contracting, project management, equipment operators, iron workers, and millwrights

- transportation: truck, rail, and barge 
- manufacturing and supply chain: research and development, raw materials, welding, fabricating, machining, and assembly

- finance: project finance, insurance, and risk assessment

- asset management and operations: wind technicians, field and regional managers; component repair and monitoring, and control room operators.

For example, for one utility-scale distributed wind "import" supplied by a manufacturer headquartered overseas, many components were manufactured in the United States: the rotor blades were made in North Dakota, the tower was made in Tennessee, and all of the major high voltage equipment (i.e., transformers, switchgear, and control) was sourced from Colorado, Michigan, and New York. The concrete and steel used in the foundation were made by New Jersey-based companies.

While the domestic content of wind turbines has grown from around 30\% in 2006 to approximately $70 \%$ in 2012 (Wiser 2013), imports are somewhat higher for mid-sized and utility-scale distributed wind projects due in part to the limited choices of U.S.-manufactured wind turbines.

\subsection{Rare Earth Minerals}

After a huge run-up in 2011, when China temporarily halted exports of rare earth minerals, prices of the commodities dropped substantially in 2012 - though by no means to pre-2011 levels.

Looking forward, industry analysts generally anticipate a relatively stable market for rare earth minerals, which are used in high-efficiency magnets popular both in the small wind turbine industry and in utility-scale direct-drive turbines for offshore applications. The 2011 price spike helped a number of new rare earth development projects move forward, including a major project at Mountain Pass, California; those projects (in Australia, Russia, South Africa, and elsewhere) are expected to begin to provide a stabilizing influence on the market.

At the same time, industry experts warn that China, which produces $85 \%$ to $90 \%$ of global rare earth ores and consumes $65 \%$ to $70 \%$, remains an overwhelmingly dominant force in the market, which means that future price volatility cannot be ruled out. In addition, experts caution that Chinese production data may not be reliable. Further, supplies of dysprosium, the rarest among the rare earth minerals and an important component of magnets for high-temperature applications, are expected to remain very tight in the near term.

A high percentage of modern small wind systems use rare earth magnets to achieve the reliability and maintenance advantages of direct-drive generators. Manufacturers that heeded supplier warnings and locked in costs with multi-year purchase orders were spared most of the hit, but those that did not saw a relatively modest impact on their overall costs. 


\subsection{Developments, Drivers, and Barriers}

New developments in 2012 included the publication of updated U.S. $30 \mathrm{~m}$ wind resource maps. Key drivers and barriers continued to influence the distributed wind market.

\subsection{New 30 m Wind Resource Map}

In February 2012, AWS Truepower and NREL released, through DOE's Wind Powering America program, new $30 \mathrm{~m}$ height, high-resolution wind resource maps for the United States. The overall map of the United States is shown in Figure 31 and higher resolution individual state maps are also publicly available on the Wind Powering America website. These wind resource maps can be used as a first step in identifying sites that may be appropriate for wind projects with adequate wind resources at lower hub heights.

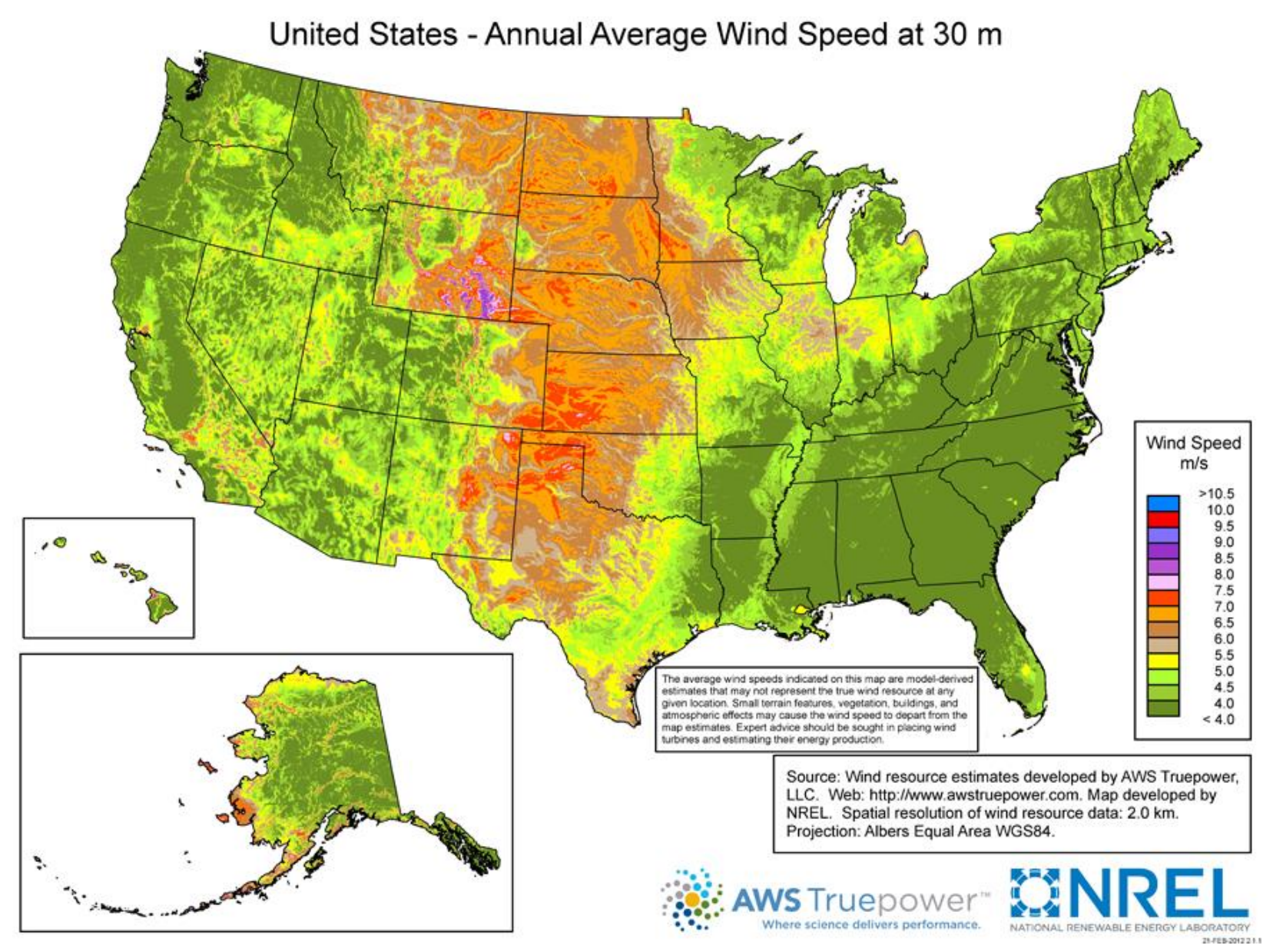

Figure 31. Residential-Scale $30 \mathrm{~m}$ Wind Map (NREL 2012) 


\subsection{Market Drivers}

The 2012 growth of the U.S. distributed wind market, albeit mixed within sectors, was a result of a combination of factors, including the continued interest by many electricity consumer classes to become more energy independent, to lower and stabilize their current and future utility bills, and to contribute positively to the environment. While lower natural gas prices influence electricity prices and have therefore temporarily dampened utility bills as a short-term economic driver, historic volatility and rising gas and coal prices make some consumers wary of electricity derived from fossil fuels. State incentives led to much of the 2012 success in small wind, and the pending expiration of the ITC for mid-sized and utility-scale wind and termination of the Section 1603 payments motivated many distributed wind developers and owners to install their projects and have them operational by the end of 2012 .

\subsubsection{Electricity Prices}

A combination of lower natural gas prices and generally mild temperatures contributed to the 2012 decline in wholesale electricity rates compared to 2011 (EIA 2013a). Between January 2012 and January 2013, the national average residential retail price increased only $0.7 \%$ (EIA $2013 \mathrm{~b}$ ) compared to $4.4 \%$ the previous year, and below the annual consumer inflation rate of $1.7 \%$. Electricity prices fell in several states including Illinois (-9.3\%), Alaska (-9.3\%), and Massachusetts (-2.9\%) while increasing in others including Iowa (8.5\%), Colorado (6.2\%), Hawaii (5.3\%), and Minnesota (5.2\%) (EIA 2013c).

Typically, rising and variable energy prices drive interest in distributed wind, particularly in the agricultural sector and among consumers motivated to seek energy independence. Investments in onsite wind turbines offer a way to stabilize long-term energy costs.

\subsubsection{Distributed Energy Storage Creates and Reduces Demand}

As the number of renewable energy installations increases, systems that can more efficiently integrate the contributions of solar and wind energy into the grid are attracting the attention of utilities and systems integrators. Distributed energy storage (DES) is gaining momentum as a strategy to help compensate for the variable generation of renewable energy sources and enable a dispatchable power supply to assist in balancing and adjusting grid conditions and avoiding frequent ramping up-and-down of baseload generation.

For commercial electricity customers, charging batteries at night (e.g., from excess wind energy) and then delivering that power during the day to reduce peaks in demand is an effective method of reducing electricity costs and supporting grid stability. The advantage to DES for onsite renewable generators is the ability to accommodate spikes in demand or reductions in generation by flattening the demand curve. DES also has the ability to survive power outages with minimal disruption to the commercial operation. 
A number of small wind turbine manufacturers are either exploring or entering into partnerships with energy storage companies to develop modular systems for use in emergency operations as well as remote locations. With the maturation of smart grid technologies and the recognition of locally distributed power resiliency, especially on microgrids, more distributed wind applications combined with DES will serve loads closer to the actual generation site.

\subsection{Education and Public Awareness}

From kindergarten through college, various groups are working to educate students about wind energy, which also increases public awareness of distributed wind.

\subsubsection{Wind for Schools}

In 2008, DOE issued a report describing a future where $20 \%$ of power comes from wind energy by 2030 . According to the report, 500,000 new annual full-time equivalent jobs would be supported under a $20 \%$ wind scenario. As part of an effort to develop a skilled workforce, DOE launched its Wind for Schools project to equip college and university students with an education in wind energy applications; engage American communities in wind energy applications, benefits, and challenges; and introduce teachers and students to wind energy.

The Wind for Schools project operates in 12 states (Alaska, Arizona, Colorado, Idaho, Illinois, Kansas, Montana, North Carolina, Nebraska, Pennsylvania, South Dakota, and Virginia). Five of these states received direct funding from DOE's Wind Program in 2012. The six original Wind for Schools states and the Illinois affiliate program support activities at the Wind Application Centers (WACs) ${ }^{14}$ and turbine installations as funding allows.

\section{DOE's Vision for Wind Power in the United States}

The DOE Wind Program, in close cooperation with the wind industry, is launching a new initiative to revisit the findings of the 2008 DOE $20 \%$ Wind Energy by 2030 report and to develop a renewed vision for U.S. wind power research, development, and deployment.

This effort will include the following:

- a characterization of industry progress and how recent developments and trends impact the 2008 conclusions

- a discussion of the costs and benefits to the nation arising from more wind power

- a roadmap addressing the challenges to achieving high levels of wind (land-based utility-scale, offshore, and distributed) within a sustainable national energy mix.

In addition to documenting and analyzing the current status of wind technologies and the wind industry, the objectives of the initiative include the following:

- provide leadership in development of a cohesive long-term vision for the benefit of the broad U.S. wind power community

- analyze a range of aggressive but attainable industry growth scenarios

- provide best available information to address stakeholder concerns

- provide objective and relevant information for use by policy and decision makers.

\footnotetext{
${ }^{14}$ WACs at universities provide hands-on learning experiences for students who serve as project consultants for wind turbines installed at K-12 schools.
} 
In 2012, 31 Wind for School project turbines were installed, bringing the total number of installations at host schools to 125. At the university level, dozens of students graduated in 2012 with active involvement in the WACs, either through class work or direct involvement in the Wind for Schools project.

The Wind for Schools project has worked closely with the KidWind Project, described below, and the National Energy Education Development Project to support curricula development and implementation at the K-12 levels, increasing use of wind turbine data in the classroom while ensuring that students actively engage in interactive learning.

\subsubsection{KidWind Project}

Education continues to be an important driver for distributed wind. The KidWind Project hosts state competitions to engage youth, teachers, and the school community with a hands-on wind energy learning experience. Its members also continue to work closely with the Wind for Schools project.

In 2012, the KidWind Project hosted 20 KidWind Challenge competitions in 13 states and Canada, with nearly 1,500 students competing. In 2013, an estimated 2,500 students will compete in approximately $30 \mathrm{KidWind}$ Challenge competitions in more than 15 states.

In addition, the KidWind Project launched the global web-based KidWind Challenge and the second edition of its WindWise educational curriculum. Planning is underway for the National KidWind Challenge Finals Competition at the USA Science and Engineering Festival in Washington, DC, in April 2014.

In 2012, 25 new Wind Senators (master teacher-trainers) attended a week-long training course in Bar Harbor, Maine. There are now 91 official Wind Senators, and plans are underway to train approximately 50 additional Wind Senators via workshops in Palm Springs, California and Portland, Oregon in 2013. In addition to the Wind Senators, KidWind Project trainers trained more than 1,500 classroom teachers on wind energy science in the United States, the Caribbean, Ireland, and Taiwan.

Members of the KidWind Project will also serve as advisors for DOE's Inaugural National Collegiate Wind Energy Competition in spring 2014.

\subsection{Operations and Maintenance Costs}

While much research and data collection efforts are focused on project operations and maintenance $(\mathrm{O} \& \mathrm{M})$ costs for utility-scale wind projects, parsing out O\&M costs for distributed wind projects using mid-size and utility-scale turbines is challenging, especially for the mid-size market because of its small size. In addition, no industry-standard reporting method exists for O\&M costs. 
With industry partners GL Garrad Hassan and DNV KEMA, NREL has compiled data for about $10 \mathrm{GW}$ of operating utility-scale wind projects in the United States. According to this database, total project O\&M costs (which include soft costs ${ }^{15}$, turbine O\&M, and balance-of-plant O\&M) for projects operating in the past 10 years range from $\$ 40$ to $\$ 60$ per installed $\mathrm{kW}$ (Lantz 2013). NREL's data suggests that O\&M costs start on the low end of the range when projects first become operational, but increase as projects age. Similar research on O\&M costs for utility-scale turbine projects is presented in Lawrence Berkeley National Laboratory's annual Wind Technologies Market Report (Wiser and Bolinger 2012).

These O\&M cost figures are for large, multi-turbine projects which likely enjoy some level of economies of scale. Distributed projects using just one or two utility-scale turbines may experience higher O\&M costs and related energy losses. This is because smaller projects tend to rely on maintenance personnel who are often located far from the project site, leading to longer response times in the event of an outage, and who are often not full-time turbine maintenance professionals, and may be less efficient with routine maintenance and repairs. In addition, a single-turbine outage at a distributed-scale project results in a far greater percentage of lost power than that at a commercial wind farm.

According to one developer who uses mid-size wind turbines in distributed wind projects, the scheduled and unscheduled maintenance costs for mid-size turbines is in the range of 500 to 900 $\mathrm{kW}$ average about $1.2 \phi / \mathrm{kWh}$, or roughly $\$ 30 / \mathrm{kW}$ per year. The scheduled and unscheduled maintenance costs for a $100 \mathrm{~kW}$ turbine averages $\$ 30 / \mathrm{kW}$ to $\$ 35 / \mathrm{kW}$ per year, or roughly $2 \notin / \mathrm{kWh}$ to $2.5 \notin / \mathrm{kWh} .^{16}$

Annual O\&M costs for small wind systems (up through $100 \mathrm{~kW}$ in size) vary widely, with current estimates from leading manufacturers ranging from $\$ 13$ to $\$ 93$ per $\mathrm{kW}$. At typical

\footnotetext{
${ }^{15}$ Soft costs include expenses such as audit compliance costs, fees, and royalty payments.

${ }^{16} \mathrm{O} \& \mathrm{M}$ cost per $\mathrm{kWh}$ calculation is based on average turbine performance in a Class 2 wind resource.
} 
capacity factors of 16 to $26 \%$ in wind sites with $5 \mathrm{~m} / \mathrm{s}$ annual wind speeds at hub height, labor costs to keep small wind turbines running reliably results in $1 \notin$ to $7 \notin$ per $\mathrm{kWh}$. In higher wind sites of $6 \mathrm{~m} / \mathrm{s}$, O\&M costs are estimated to average $0.6 \notin$ per $\mathrm{kWh}$ for one established residential wind turbine model designed to require no annual scheduled maintenance with more than 2,500 units installed in the field and a combined total fleet operating time exceeding 200 million hours, and $2 \varnothing$ to $4 \phi$ per $\mathrm{kWh}$ for three other leading grid-tied small wind turbine models.

Most small wind suppliers prefer to frame O\&M costs on an annual basis. Refurbished turbines may see even higher annual costs depending on the extent of parts replacement prior to reinstallation. On the lower end, $\$ 130$ to $\$ 500$ per year is expected for residential systems and $\$ 2,700$ to $\$ 3,500$ per year for farm/small business-sized small wind turbines.

These estimates are roughly in line with data collected for NREL's JEDI tool shown in Table 7.

Table 7. Preliminary Small Wind Annual O\&M Cost Assumptions Used in JEDI (Tegen 2013)

\begin{tabular}{cc}
\hline Turbine Size & O\&M Cost per Year \\
\hline Up to $2.4 \mathrm{~kW}$ & $\$ 60-\$ 65 / \mathrm{kW}$ \\
2.5 to $10 \mathrm{~kW}$ & $\sim \$ 10 / \mathrm{kW}$ \\
10.1 to $50 \mathrm{~kW}$ & $\$ 50-\$ 55 / \mathrm{kW}$ \\
50.1 to $100 \mathrm{~kW}$ & $\$ 20-\$ 25 / \mathrm{kW}$ \\
\hline
\end{tabular}

\subsection{Market Barriers}

Distributed wind continues to face significant market barriers. Some of the challenges can be viewed in the differences in market characteristics between solar and wind, particularly small wind. For solar, PV modules are approaching commodity status, while small wind is still based on small-scale manufacturing. The solar industry has well-established testing requirements, while the certification process for small and mid-size wind turbines is relatively new. Resource uncertainty is low for solar, but resource assessment and micro-siting can be challenging for small wind. Permitting for solar systems is typically more straightforward than it is for wind. Finally, solar systems normally have low maintenance requirements, but maintenance can be critical for wind.

Residential demand for small wind systems (typically $<11 \mathrm{~kW}$ ) remained low from lackluster 2011 sales after record growth in 2009 and 2010. A combination of factors led to the continued decline in residential U.S. sales. Rapidly decreasing prices for solar PV $(80 \%$ over the last 5 years) and more favorable financing terms for solar provided stiff competition for domestic small wind systems. State incentive programs for wind systems remained in flux, with California rebates offered only for a brief period in 2012, previous leading programs in New Jersey, Ohio, and Wisconsin remained closed, while New York, Nevada, and Iowa experienced significant growth. Consumer confidence and access to capital remained fragile, especially for small wind systems that did not have access to third-party leasing schemes that boosted PV. In 
addition, in a number of states, foundational net metering and interconnection policies were under attack in legislatures and at utility commissions. While Section 1603 payments were still available for projects that started construction in 2012, the majority of the eligible small wind turbine projects had been installed prior to 2012 .

Mid-size and utility-scale distributed wind project development met similar barriers, including the weak domestic economy, inconsistent state incentives, and very competitive PV and natural gas prices.

Another continuing barrier to onsite applications is matching adequate wind resources with large loads and reasonable permitting environments, and then convincing customers to sign long-term contracts, and getting the permits and financing in time to meet the anticipated ITC expiration date (extended in January 2013). A business model of third-party ownership supplying wind energy from utility-scale turbines at host sites, reducing utility energy requirements and costs, is being expanded to help address this barrier, in part at the request of national and regional companies which have hosted such projects in California.

Solar incentives, lower PV costs, and low natural gas prices were serious barriers to onsite midsize and utility-scale generation in the northeastern United States; for example, in New York the PV competition was intense, resulting in no utility-scale distributed wind installations and only one mid-size distributed wind project installed in 2012.

While investor-owned utilities were the primary purchasers of the output of distributed wind IPP projects, municipalities and rural electric co-ops were also in the mix of power purchasers. The increasing retail rates and commercial consumer interest in behind-the-meter applications aided the market in the Midwestern United States, although projects there were challenged by demandcharges in the tariff structures. 


\subsection{Market Outlook}

Distributed wind power capacity additions in 2012 totaled $175 \mathrm{MW}$, representing more than $\$ 410$ million in domestic investment. As a point of reference, total U.S. wind capacity installed in 2012 was 13.1 GW (AWEA 2013). The market outlook for 2013 and beyond will be impacted by the expiration of the U.S. Treasury Section 1603 program, the use of alternate financing models, tapping into growing market segments, and other factors.

\subsection{Using Solar Business Models to Expand the Distributed Wind Market}

A total of 3,313 MW of residential, non-residential, and utility solar PV was installed in 2012 (GTM and SEIA 2013a). Third-party ownership models supported the growth of the residential market, with over 82,000 homes installing solar PV in 2012 (GTM and SEIA 2013b). Under the two typical forms of solar PV third-party finance, the PPA and lease models, financiers who own the system - rather than the property owner or homeowner — are often able to utilize tax benefits unavailable to homeowners. In addition to these options, solar installations employ a variety of financing models that include partnership flips, complex financial structures (i.e., saleleaseback transactions and inverted leases), and community-purchased projects funded by individual investors.

Currently, the small wind industry has started to explore similar financing options, such as leaseto-own and PPAs, in addition to direct purchases. However, wind project installations face different challenges than solar PV installations. Institutions providing financial packages require reliability, proven performance, and assurance of long-term maintenance capabilities for renewable energy systems. Financing partners look for replicable packages and high volume and in most cases small wind turbines' performance and O\&M costs are variable. A third-party certification process has only recently been established for small wind (e.g., the SWCC). Wind resource assessment techniques and tools have improved; thus, performance predictions are also improving. Further, established organizations are entering the maintenance business, giving financiers more confidence in the long-term maintenance and operation of small turbines. As the small wind industry continues to improve and increase these aspects of the market, use of these alternative financing options is likely to increase.

\subsection{Solar Market Outlook}

Compared to the exceptional growth in domestic PV installations in 2011 and 2012, industry analysts expect more moderate PV market growth in 2013 (GTM and SEIA 2013a). Positive market conditions for large renewable projects support continued robust utility-scale PV development with $4.8 \mathrm{GW}$ of projects under construction. However, this trend may give way to smaller projects. 
The Solar Energy Industry Association anticipates a "resurgence in distributed generation" in the coming years compared to the dominance of utility-scale PV projects over the past few years, as discussed in Section 7.2.1. As more electric utilities complete compliance with their RPS requirements and incentives expire, construction of utility-scale PV projects is expected to slow. However, due to the current ITC expiration date for solar, 2016 could be a banner year for the U.S. solar market (as well as for small wind) as developers hurry to complete projects.

Projected growth in the PV distributed generation market is based on the trend of declining average system price coupled with the continuation of capital investment in popular third-party ownership leasing models (Lacey 2013). Adding to the positive market movement are new policies in New Jersey and Colorado highlighting the importance elected leaders in those states place on a thriving distributed generation industry and local economic stability.

In July 2012, New Jersey altered its RPS schedule and now requires electric energy suppliers to purchase Solar Renewable Energy Certificates (SRECs) to meet a percentage of their fuel portfolios rather than meet fixed megawatt-hour allotments. Eligible distributed generation projects can sell their SRECs during the first 15 years of system operation. Colorado's legislature approved an increase in the RPS for rural electric cooperatives with a solar and distributed wind carve-out. In 2012, New Jersey and Colorado were ranked the third and ninth states respectively in installed PV capacity for the year (GTM and SEIA 2013a).

Solar industry leaders are investigating new strategies to expand financial tools available for investing in renewable energy projects (Konrad 2012). Increasing the opportunities for a broader range of investors is the goal of clarifying whether solar projects can be qualified as Real Estate Investment Trusts (REIT). The industry is waiting for the IRS to rule on the qualification issue before it can establish solar REITs that own and operate PV power plants and pay investors dividends.

Another investment structure advocated by PV financing leaders is Master Limited Partnerships (MLPs), which are taxed like partnerships but traded like stocks. Investors favor MLPs because they can buy and sell shares in the public markets; project developers like MLPs because they can access cheaper capital through the markets. In late 2012, a bipartisan group of Senators and Representatives sent a letter to President Obama requesting a REIT ruling and MLP reform to move renewable energy investments ahead.

Despite the growing perception of the solar market's ability to stand on its own, the U.S. solar industry faces serious challenges and uncertainty spurred by global factors (e.g., oversupply of PV modules and overcapacity of manufacturing facilities) (Colville 2012). Many PV manufacturers have experienced double-digit percentage losses, and several have filed or are confronting bankruptcy as the PV industry corrects its supply-demand imbalance and adjusts to changes in international trade regulations. 


\subsection{U.S. Community Wind Market}

Community wind, characterized by local ownership and control, includes many distributed wind projects. The drivers for these projects varied regionally; but offsetting expensive and rising energy costs to utilities and net metered facilities dominated in 2012 California and Alaska village projects. IPP projects in the Midwest were driven by champions who saw the opportunity to join with their neighbors to use their windy land as a long-term source of income to augment uncertain future farm commodity prices, with federal and state incentives available to help ensure economic projects.

While interest is increasing in community wind because it adds local economic development benefits, the long-term outlook for community wind is unclear, primarily due to the uncertainty of federal and state policies that enable community wind projects to be economically attractive. The short-term situation is mixed as well, primarily for the same policy reasons. The expiration of the U.S. Treasury Section 1603 program, the uncertainty of the USDA REAP program, and PURPA challenges in the Midwest and Western states have reduced community wind's competiveness. While the 2013 extension of the ITC is important in the short term, longer term federal incentives are needed to stabilize the community wind market. Several states have provided incentives that have helped community wind economics, but many programs are facing funding cuts due to state budget shortfalls related to the sluggish economy. Low avoided cost PURPA rates for IPPs are expected to rebound with natural gas prices. Turbine technology advancements that improve capacity factors and the increased availability of turbines to community wind projects are positive developments that have helped all wind projects.

Financing of community wind projects remains a challenge, especially monetizing tax credits and attracting equity partners. Several emerging financing instruments (e.g., Qualified Energy Conservation Bonds [QECBs] and New Markets Tax Credits [NMTCs], described above in Section 6.2.4) were in play in 2012, and community wind developers will pursue other financing instruments in 2013 to expand the pool of funds and investors.

\subsubsection{Relationship to Small, Mid-Size, and Utility-Scale Distributed Applications}

DOE's designation of distributed wind as wind systems connected to distribution grids (i.e., connected on the customer side of the meter to meet the onsite load or directly to local distribution or micro grids to support grid operations or offset large loads nearby) differentiates this market from the transmission and sub-transmission grids that transmit wholesale power from large generators to substations for subsequent distribution to loads. Distributed wind projects are defined by their interconnection and load-serving characteristics, so the distributed wind market includes turbines and projects of many sizes.

The term community wind is defined by local project ownership and control and is not necessarily limited by turbine or project size or line function (distribution or transmission). Distributed wind projects can also be considered community wind projects if they are locally 
owned and controlled. However, some distributed wind projects are not community wind projects. For example, a behind-the-meter project on a school or industrial facility is distributed, but has a third-party owner who sells the energy to the facility host.

Small wind is defined as wind turbines that are $100 \mathrm{~kW}$ or less. In general, all small wind, with some exceptions, is considered distributed wind, because it is typically not interconnected with transmission or sub-transmission grids. One exception includes an Alaska village power project's use of small turbines (typically in conjunction with diesel generators). Though the turbines are community-owned, the project may not be considered distributed due to its centralized generation.

\subsection{U.S. Rural Residential and Farm Markets}

While the U.S. residential wind market was down in 2012, sales of wind systems to farms and ranches remained level from 2011, reflecting both high commodity process (which allow for strong farmer incomes) and high electricity costs. This market segment was bolstered by refurbished turbines in the 40 - to $100-\mathrm{kW}$ range.

Domestic farm markets are expected to pick up in 2013 and 2014 as states with "Right to Agricultural Use" policies become a stronger focus for industry outreach. Following the remarkable success of recently established solar PV financing models, a new company, United Wind introducing third-party leasing for distributed wind also expects strong growth in the U.S. rural residential markets.

\subsection{Emerging Markets and Applications}

The U.S. military has committed to a goal of developing $3 \mathrm{GW}$ of renewable energy by 2025: the U.S. Navy plans to develop $1 \mathrm{GW}$ of renewable energy on its installations by 2020, the U.S. Air Force plans for $1 \mathrm{GW}$ by 2016, and the U.S. Army plans for $1 \mathrm{GW}$ by 2025 (White House 2012). While PV seems to be making some inroads, small wind manufacturers are finding it difficult to participate in the military's process-heavy opportunities. The General Services Administration continues to pursue energy technologies, but small wind has only captured a handful of applications; PV, urban settings, perceived mission conflicts, and process hurdles have been barriers to significant penetration of this large market.

Alaska has steadily emerged over the last 10 years as a leader in utilizing small wind in hybrid wind-diesel village power systems; however, while thousands of isolated diesel village systems power the developing world, it has been a challenge for U.S. small wind companies to establish a workable business model for sustained deployment and operations. The international development community has shown renewed interest in renewable retrofits of diesel micro and mini-grid systems to provide cleaner, more sustainable $24 / 7$ power for education, health services, and micro-enterprise. Experience with Alaska wind-diesel systems should help the U.S. industry penetrate this potentially large market. 


\subsection{Expansion of International Suppliers Presence in the United States}

Distributed wind manufacturers prospering from strong sales to the UK and other growing markets are looking to the U.S. workforce to expand their facilities. International wind turbine manufacturers are eager to participate in the U.S. market. Several are developing partnerships with distributed wind stakeholders and looking for appropriate areas with steady markets to locate facilities in the United States.

\subsection{Overall 2013 Prospects}

The one-year extension of the federal PTC and its new start construction language are expected to create a 2 to 3 year window for additional utility-scale wind project development; however, the changes are likely to have only a small impact on distributed wind projects.

The USDA's fiscal year 2014 budget proposes increased levels of mandatory funding for loan guarantees and grants over 2012 levels for the REAP (USDA 2012), which will continue to support the development of distributed wind projects in the rural and farm markets.

An unveiling of distributed wind third-party leasing by several industry leaders working together as United Wind is anticipated to boost the residential market in 2013, and industry leaders are pursuing financing models for mid-size wind with local and regional banks similar to those available for large solar projects.

Outreach work on behalf of the distributed wind industry is building on the successes of popular solar-specific programs. This outreach is helping to open markets with various federal agencies and leading a movement toward technology-neutral distributed generation policies.

While several distributed wind suppliers expect 2013 sales to be strong, others recognize serious challenges and continued competition with growth prospects dependent on the state of the global economy. 


\subsection{Data Tables}

Detailed data provided for reference.

Table 8. Megawatts By Year By Sector

\begin{tabular}{lccccccccccc}
\hline & $\mathbf{2 0 0 3}$ & $\mathbf{2 0 0 4}$ & $\mathbf{2 0 0 5}$ & $\mathbf{2 0 0 6}$ & $\mathbf{2 0 0 7}$ & $\mathbf{2 0 0 8}$ & $\mathbf{2 0 0 9}$ & $\mathbf{2 0 1 0}$ & $\mathbf{2 0 1 1}$ & $\mathbf{2 0 1 2}$ & Cumulative \\
\hline Small Wind Turbines & 3 & 5 & 3 & 9 & 10 & 17 & 20 & 26 & 19 & 18 & $\mathbf{1 3 1}$ \\
Mid-Size Distributed & 19 & 7 & 4 & 3 & 3 & 14 & 9 & 9 & 12 & 19 & $\mathbf{1 0 0}$ \\
Utility-Scale Distributed & 10 & 19 & 18 & 53 & 39 & 72 & 92 & 63 & 76 & 138 & $\mathbf{5 8 1}$ \\
All Distributed Wind & $\mathbf{3 2}$ & $\mathbf{3 1}$ & $\mathbf{2 6}$ & $\mathbf{6 5}$ & $\mathbf{5 1}$ & $\mathbf{1 0 4}$ & $\mathbf{1 2 1}$ & $\mathbf{9 8}$ & $\mathbf{1 0 8}$ & $\mathbf{1 7 5}$ & $\mathbf{8 1 2}$ \\
\hline
\end{tabular}

Table 9. Units By Year By Sector

\begin{tabular}{lccccccccccc}
\hline & $\mathbf{2 0 0 3}$ & $\mathbf{2 0 0 4}$ & $\mathbf{2 0 0 5}$ & $\mathbf{2 0 0 6}$ & $\mathbf{2 0 0 7}$ & $\mathbf{2 0 0 8}$ & $\mathbf{2 0 0 9}$ & $\mathbf{2 0 1 0}$ & $\mathbf{2 0 1 1}$ & $\mathbf{2 0 1 2}$ & Cumulative \\
\hline Small Wind Turbines & 3,200 & 4,700 & 4,300 & 8,300 & 9,100 & 10,400 & 9,800 & 7,800 & 7,300 & 3,700 & $\mathbf{6 8 , 6 0 0}$ \\
Mid-Size Distributed & 24 & 9 & 6 & 7 & 9 & 17 & 15 & 22 & 22 & 31 & $\mathbf{1 6 0}$ \\
Utility-Scale Distributed & 5 & 12 & 12 & 40 & 22 & 43 & 63 & 34 & 42 & 78 & $\mathbf{3 5 0}$ \\
All Distributed Wind & $\mathbf{3 , 2 0 0}$ & $\mathbf{4 , 7 0 0}$ & $\mathbf{4 , 3 0 0}$ & $\mathbf{8 , 3 0 0}$ & $\mathbf{9 , 1 0 0}$ & $\mathbf{1 0 , 5 0 0}$ & $\mathbf{9 , 9 0 0}$ & $\mathbf{7 , 9 0 0}$ & $\mathbf{7 , 4 0 0}$ & $\mathbf{3 , 8 0 0}$ & $\mathbf{6 9 , 0 0 0}$ \\
\hline
\end{tabular}

Table 10. 2012 Cost Per Kilowatt

\begin{tabular}{llccc}
\hline & \multicolumn{1}{c}{ Sample Size } & $\begin{array}{c}\text { Average } \\
\mathbf{\$} / \mathbf{k W}\end{array}$ & $\begin{array}{c}\text { Min } \\
\mathbf{\$} / \mathbf{k W}\end{array}$ & $\begin{array}{c}\text { Max } \\
\mathbf{\$} / \mathbf{k W}\end{array}$ \\
\hline Small Wind Turbines - New Domestic & 3,209 units $(6.3 \mathrm{MW})$ & $\$ 6,510$ & $\$ 1,500$ & $\$ 27,500$ \\
Small Wind Turbines - New Imported & 348 units $(2.6 \mathrm{MW})$ & $\$ 8,040$ & $\$ 4,590$ & $\$ 16,700$ \\
Small Wind Turbines - Refurbished & 105 units $(9.6 \mathrm{MW})$ & $\$ 4,080$ & $\$ 3,560$ & $\$ 7,480$ \\
Subtotal Small Wind Turbines & $\mathbf{3 , 6 6 2}$ units (18.4 MW) & $\mathbf{\$ 5 , 5 0 0}$ & $\mathbf{\$ 1 , 5 0 0}$ & $\mathbf{\$ 2 7 , 5 0 0}$ \\
Mid-Size Distributed & 17 turbines, 8 projects $(9.5 \mathrm{MW})$ & $\$ 2,810$ & $\$ 2,400$ & $\$ 3,350$ \\
Utility-Scale Distributed & 43 turbines, 26 projects (78 MW) & $\mathbf{\$} 2,540$ & $\$ 1,760$ & $\$ 4,000$ \\
All Distributed Wind & $\mathbf{3 , 7 7 2}$ units (106 MW) & $\mathbf{\$ 3 , 0 7 0}$ & $\mathbf{\$ 1 , 5 0 0}$ & $\mathbf{\$ 2 7 , 5 0 0}$ \\
\hline
\end{tabular}

Table 11. 2012 Application Type

\begin{tabular}{lccc}
\hline & Project Count & Turbine Count & Total MW \\
\hline Small Wind Turbines Off-Grid & approx 2,600 & approx 2,600 & 1 \\
Small Wind Turbines Grid-Tied & approx 1,000 & approx 1,000 & 17 \\
Mid-Size Onsite & 2 & 6 & 5 \\
Utility-Scale Onsite & 17 & 26 & 50 \\
Subtotal Onsite & approx 3,600 & approx 3,600 & $\mathbf{7 3}$ \\
Mid-Size Distribution Grid & 20 & 25 & 14 \\
Utility-Scale Distribution Grid & 30 & 52 & 88 \\
Subtotal Distribution Grid & $\mathbf{5 0}$ & $\mathbf{7 7}$ & $\mathbf{1 0 2}$ \\
\hline
\end{tabular}




\subsection{References}

Andrew. 2013. Chinese Solar Imports Drop But Prices Continue to Fall. Cleantech News. Access May 2013 at http://cleantechnica.com/2013/01/22/chinese-solar-imports-drop-but-prices-continue-to-fall/ (last updated January 22, 2013).

AWEA - American Wind Energy Association. 2012. 2011 U.S. Small Wind Turbine Market Report. AWEA, Washington, D.C.

AWEA - American Wind Energy Association. 2013. AWEA U.S. Wind Industry Fourth Quarter 2012 Market Report. Released January 30, 2013. AWEA, Washington, D.C.

Bellis E. 2012. Energy Programs Consortium Memorandum Re: QECBs. Energy Programs Consortium, New York, New York. Accessed May 2013 at http://www.naseo.org/Data/Sites/1/documents/committees/financing/resources/qecb/EPC_Memo.pdf (last update February 6, 2012).

Bolinger M. 2011. Community Wind: Once Again Pushing the Envelope of Project Finance. Lawrence Berkeley National Laboratory. LBNL-4193E. Available at http://emp.lbl.gov/sites/all/files/lbnl4193e.pdf.

Colville F. 2012. The PV industry at the end of 2012: reasons to be fearful. Pages 19-22 of Solar Business Focus, Volume 5 - 2012. Solar Media Ltd., London, UK. Available at http://dp.solarmediastore.com/i/91798.

CPUC - California Public Utilities Commission. 2013. Net Energy Metering (NEM). Accessed June 2013 at http://www.cpuc.ca.gov/PUC/energy/DistGen/netmetering.htm (last updated January 9, 2013).

Crooks A. 2013. 2012 REAP Wind projects.xlsx. Provided to Heather Rhoads-Weaver (eFormative Options) via email from Anthony Crooks (USDA Rural Development) on March 11, 2013 to supplement USDA's online Energy Investment Report information.

DSIRE - Database of State Incentives for Renewables \& Efficiency. 2013. Iowa - Alternate Energy Revolving Loan Program. Accessed May 2013 at http://www.dsireusa.org/incentives/incentive.cfm?Incentive Code $=I A 06 F \&$ re $=0 \& \mathrm{ee}=0$ (last updated April 18, 2013).

DWEA - Distributed Wind Energy Association. 2013. DWEA Model Zoning Ordinance, Final. Accessed May 2013 at http://distributedwind.org/assets/docs/PandZDocs/dwea-model-zoning-ordinancepassed-01-07-12.pdf (last update unknown).

EIA - U.S. Energy Information Administration. 2013a. 2012 Brief: Average wholesale electric prices down compared to last year. Accessed May 2103 at http://www.eia.gov/todayinenergy/detail.cfm?id=9510 (last updated January 9, 2013).

EIA - U.S. Energy Information Administration. 2013b. Table 5.3 Average Retail Price of Electricity to Ultimate Customers. Accessed May 2013 at

http://www.eia.gov/electricity/monthly/epm_table_grapher.cfm?t=epmt 5 _3 (last updated May 21, 2013).

EIA - U.S. Energy Information Administration. 2013c. Electric Power Monthly with Data for January 2013, Individual State Comparisons. Table 5.6.A. Average Retail Price of Electricity to Ultimate Customers by End-Use-Sector, by State, January 2013 and 2012 (cents per kilowatthour). Accessed May 2013 at http://www.eia.gov/electricity/monthly/current year/march2013.pdf (last updated March 2013). 
Gauntlett D and M Lawrence. 2013. Research Report: Small Wind Power: Demand Drivers, Market Barriers, Technology Issues, Competitive Landscape, and Global Market. Navigant Consulting, Inc., Boulder, Colorado.

GTM and SEIA - GTM Research and Solar Energy Industries Association. 2013a. Solar Market Insight Report, 2012 Year in Review, Executive Summary. Accessed May 2013 at

http://www.seia.org/sites/default/files/resources/ZDgLD2dxPGYIR-2012-ES.pdf (last update unknown).

GTM and SEIA - GTM Research and Solar Energy Industries Association. 2013b. Solar Energy Facts: 2012 Year-in-Review. Accessed May 2013 at

http://www.seia.org/sites/default/files/Q4\%20SMI\%20Fact\%20Sheet\%20-FINAL.pdf (last update March 14, 2013).

IUB - Iowa Utilities Board. 2013. Renewable Energy Tax Credits. Accessed May 2013 at http://www.state.ia.us/iub/energy/renewable tax credits.html (last update unknown).

IREC and Vote Solar - Interstate Renewable Energy Council and Vote Solar Initiative. 2012. Freeing the Grid. Accessed May 2013 at http://freeingthegrid.org/ (last update September 11, 2012).

IRS - U.S. Internal Revenue Service. 2013. Beginning of Construction for Purposes of the Renewable Electricity Production Tax Credit and Energy Investment Tax Credit. Notice 2103-29. Available at http://www.irs.gov/pub/irs-drop/n-13-29.pdf.

Jain A, R Damiani, and J van Dam. 2013. Development of a Simplified Loads Analysis Methodology for Small Vertical-Axis Wind Turbines (VAWTs). Poster Presentation at American Wind Energy

Association's 2013 WINDPOWER Conference \& Exhibition in Chicago, Illinois. National Renewable

Energy Laboratory, Golden, Colorado.

Konrad T. 2012. Solar REITS: A Better Way to Invest in Solar [Updated]. Forbes.com. Accessed May 2013 at http://www.forbes.com/sites/tomkonrad/2012/10/09/solar-reits-a-better-way-to-invest-in-solar/ (last updated October 9, 2012).

Lacey S. 2013. Can Better Solar Loans Slow the Surge of Third-Party Ownership? Greentech Media. Accessed May 2013 at http://www.greentechmedia.com/articles/read/to-lease-or-own-in-solar (last updated March 13, 2013).

Lantz E. 2013. Operations Expenditures: Historical Trends and Continuing Challenges. Podium Presentation at American Wind Energy Association's 2013 WINDPOWER Conference \& Exhibition in Chicago, Illinois. National Renewable Energy Laboratory, Golden, Colorado.

LBNL - Lawrence Berkeley National Laboratory. 2012a. Qualified Energy Conservation Bond (QECB) Update: New Guidance from the U.S. Department of Treasury and the Internal Revenue Service. Available at: http://financing.lbl.gov/reports/qecb-guidance.pdf.

LBNL - Lawrence Berkeley National Laboratory. 2012b. Aggregating QECB Allocations \& Using QECBs to Support the Private Sector: A Case Study on Massachusetts. Available at http://financing.lbl.gov/reports/qecb-mass.pdf.

NACo - National Association of Counties. 2006. Wind Energy Guide for County Commissioners. Accessed May 2013 at http://www.naco.org/programs/csd/Pages/GreenGovernmentInitiative.aspx under Energy Efficiency and Renewable Energy Generation Green Government Resources (last updated October 2006).

NREL - National Renewable Energy Laboratory. 2013. Jobs and Economic Development Impact Models. Available at http://www.nrel.gov/analysis/jedi/ (last updated September 5, 2012). 
NREL - National Renewable Energy Laboratory. 2012. Residential-Scale 30-Meter Wind Maps. Available at http://www.windpoweringamerica.gov/windmaps/residential_scale.asp (last update February 21, 2012).

Passera L. 2013. Interconnection: A Foundational Policy for Solar Market Expansion. Interstate Renewable Energy Council, Latham, New York. Accessed May 2013 at http://www.irecusa.org/2013/05/interconnection-a-foundational-policy-for-solar-market-expansion/ (posted May 14, 2013).

USDA - U.S. Department of Agriculture. 2012. USDA FY2014 Budget Summary and Annual Performance Plan. Accessed June 2013 at www.obpa.usda.gov/budsum/FY14budsum.pdf (last updated September 30, 2012).

USDA - U.S. Department of Agriculture. 2013. Energy Investment Report. Accessed March 2013 at http://www.usda.gov/energy/maps/report.htm (last update unknown).

Smith J., T. Forsyth, K. Sinclair, and F. Oteri. 2012. Built-Environment Wind Turbine Roadmap. National Renewable Energy Laboratory, Golden, Colorado. Available at http://www.nrel.gov/docs/fy13osti/50499.pdf.

Tegen S. 2013. How Many Jobs Are There in the Domestic Small Wind Industry? Poster Presentation at 2013 Small Wind Installers Conference in Stevens Point, Wisconsin. National Renewable Energy Laboratory, Golden, Colorado.

Treasury - U.S. Department of Treasury. 2013. LIST OF AWARDS: Section 1603 - Payments for Specified Renewable Energy Property in Lieu of Tax Credits Awardees as of February 14, 2013. Accessed February 13, 2013 at http://www.treasury.gov/initiatives/recovery/Pages/1603.aspx (last update February 13, 2013).

U.S. Census Bureau. 2013. U.S. Imports of Merchandise. Accessed May 2013 at http://www.census.gov/mp/www/cat/foreign trade/us imports of merchandise.html (updated monthly).

FWS - U.S. Fish \& Wildlife Service. 2012. Final Land-Based Wind Energy Guidelines, March 23, 2012. Accessed May 2013 at http://www.fws.gov/windenergy/ (last updated April 26, 2013).

White House. 2012. Fact Sheet: Obama Administration Announces Additional Steps to Increase Energy Security. From the Office of the Press Secretary. Available at http://wh.gov/Qej (last updated April 11, 2012).

Wind Program - U.S. Department of Energy, Energy Efficiency \& Renewable Energy, Wind Program. 2013. Distributed Wind. Available at wind.energy.gov/wind dist tech.html (last update May 2, 2013).

Wiser R and M Bolinger. 2012. 2011 Wind Technologies Market Report. Lawrence Berkeley National Laboratory, Berkeley, California. Available at wind.energy.gov/pdfs/2011_wind technologies_market_report.pdf.

Wiser R. 2013. 2012 Wind Technologies Market Report Summary. Podium Presentation at Wind Powering America's 2013 All-States Summit. Lawrence Berkeley National Laboratory, Berkeley, California. Available at http://www.windpoweringamerica.gov/pdfs/workshops/2013 summit/wiser.pdf. 


\subsection{Resources}

American Wind Energy Association: www.awea.org

Database of State Incentives for Renewables \& Efficiency: www.dsireusa.org

Distributed Wind Energy Association: www.distributedwind.org

KidWind Project: www.kidwind.org

Lawrence Berkeley National Laboratory: www.lbnl.gov

National Energy Education Development (NEED) Project: www.need.org

National Renewable Energy Laboratory: www.nrel.gov

Pacific Northwest National Laboratory: www.pnnl.gov

U.S Department of Energy Wind \& Water Program Distributed Wind Energy:

http://wind.energy.gov/wind_dist tech.html

Wind for Schools Project: http://www.windpoweringamerica.gov/schools_wfs_project.asp

Wind Powering America: www.windpoweringamerica.gov 
Cover Photos Credits/Acknowledgments: 1.65-MW Vestas at Heartland Community College, Normal, Illinois, courtesy of Andrew Trapanese, Harvest the Wind Network; three 10-kW Bergey turbines at a school in Bethel, Alaska, courtesy of Michael Bergey, Bergey Windpower; 750-kW Aeronautica Windpower 54-750 at Kenston High School, Chagrin Falls, Ohio, courtesy of Ole Sangill, Norwin A/S; 50-kW E-3120 Endurance with school buses, courtesy of Craig Myers, Myers Equipment Corporation; 1.5-MW GE at Anheuser-Busch in Fairfield, California, courtesy of John Pimentel, Foundation Windpower. 
For more information, visit:

wind.energy.gov/wind_dist_tech.html 